Prepared in cooperation with the U.S. Air Force

Comparison of Passive and Pumped Sampling Methods for Analysis of Groundwater Quality, Kirtland Air Force Base, Albuquerque, New Mexic0, 2019
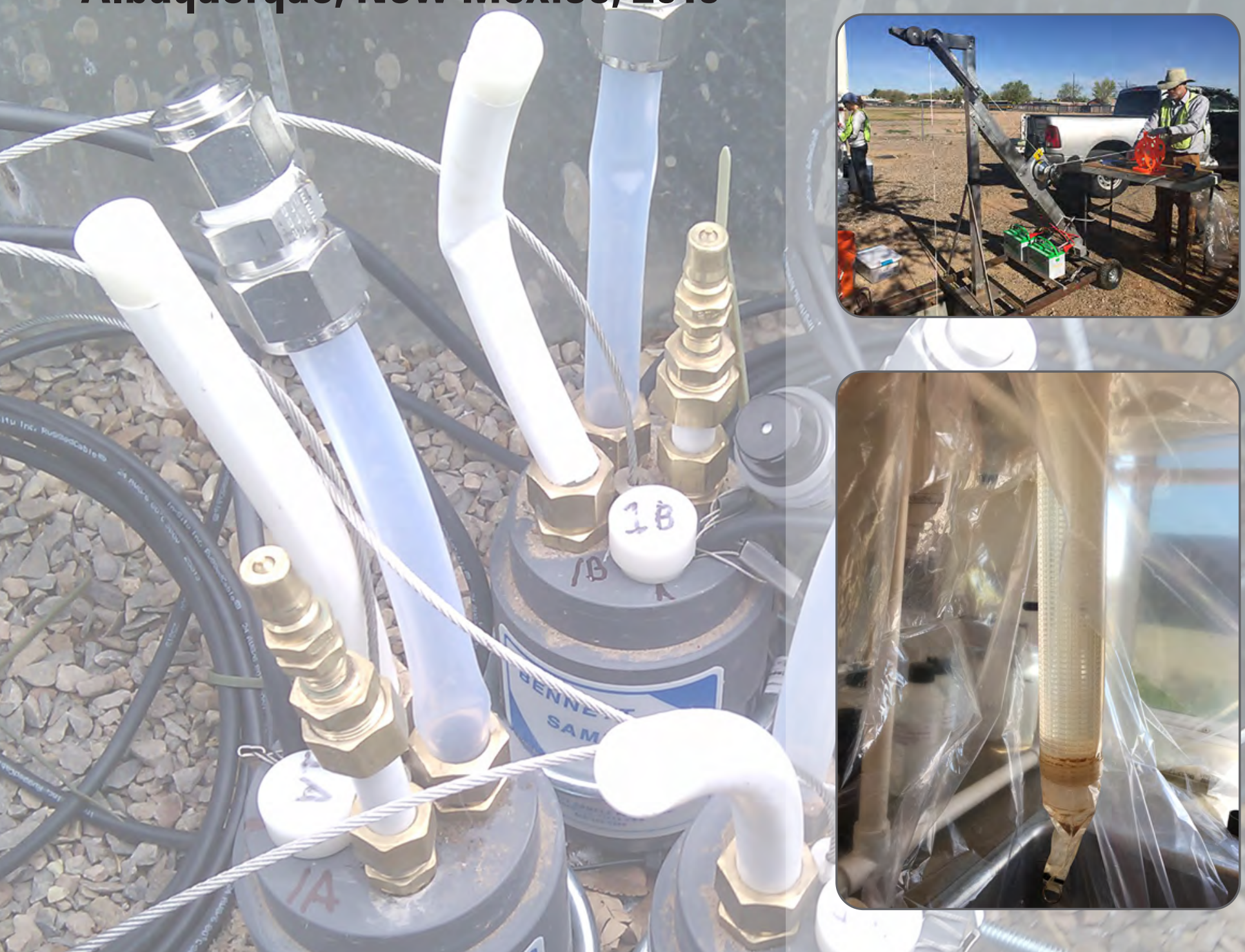

Scientific Investigations Report 2021-5074

U.S. Department of the Interior U.S. Geological Survey

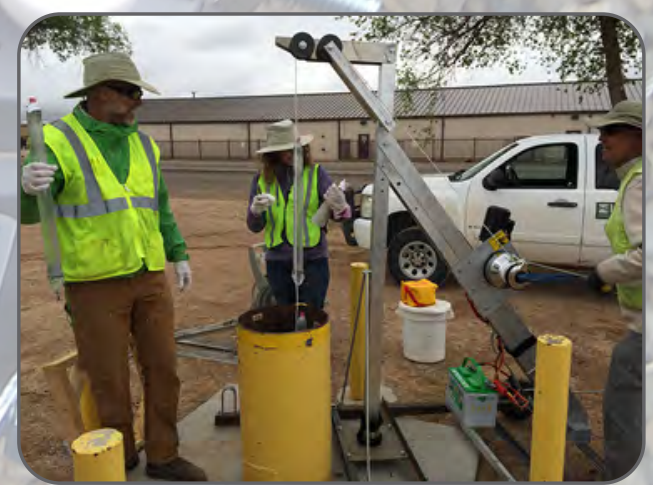




\section{Cover:}

Background, Trumbull sentinel well nest with Bennett pumps installed in 2013. Photograph by Nathan Myers (USGS).

Top inset, Retrieving Cesar Chavez Well 1A samplers. Photograph by R. Travis (USGS).

Middle inset, Sampler inside sampling chamber. Photograph by R. Travis (USGS).

Bottom inset, Retrieving VA Well 1A samplers. Photograph by R. Travis (USGS). 


\section{Comparison of Passive and Pumped Sampling Methods for Analysis of Groundwater Quality, Kirtland Air Force Base, Albuquerque, New Mexico, 2019}

By Rebecca E. Travis and Kate Wilkins

Prepared in cooperation with the U.S. Air Force

Scientific Investigations Report 2021-5074 


\section{U.S. Geological Survey, Reston, Virginia: 2021}

For more information on the USGS - the Federal source for science about the Earth, its natural and living resources, natural hazards, and the environment—visit https://www.usgs.gov or call 1-888-ASK-USGS.

For an overview of USGS information products, including maps, imagery, and publications, visit https://store.usgs.gov/.

Any use of trade, firm, or product names is for descriptive purposes only and does not imply endorsement by the U.S. Government.

Although this information product, for the most part, is in the public domain, it also may contain copyrighted materials as noted in the text. Permission to reproduce copyrighted items must be secured from the copyright owner.

Suggested citation:

Travis, R.E., and Wilkins, K., 2021, Comparison of passive and pumped sampling methods for analysis of groundwater quality, Kirtland Air Force Base, Albuquerque, New Mexico, 2019: U.S. Geological Survey Scientific Investigations Report 2021-5074, 51 p., https://doi.org/10.3133/sir20215074.

Associated data for this publication:

U.S. Geological Survey, 2019, USGS water data for the Nation: U.S. Geological Survey National Water Information System database, accessed October 24, 2019, at https://doi.org/10.5066/F7P55KJN.

ISSN 2328-0328 (online) 


\section{Contents}

Abstract

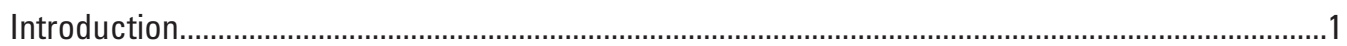

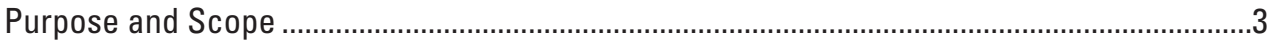

Description of Study Area ..................................................................................................

Climate

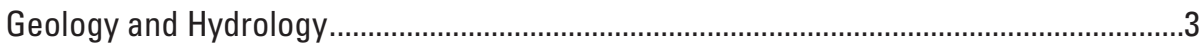

Previous Investigations.........................................................................................................

Studies Within the KAFB and Sentinel Well Area ..........................................................4

Passive Sampling Studies .............................................................................................

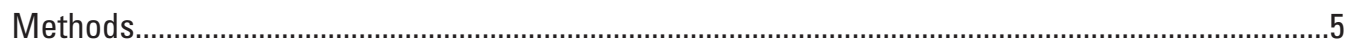

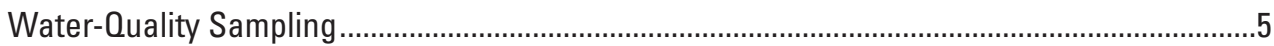

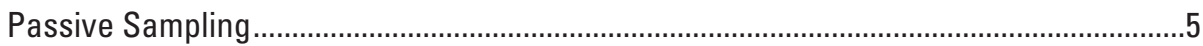

Dual-Membrane Passive Diffusion Bag Sampler.......................................................

Field Deployment and Retrieval............................................................................

Passive Sample Field Processing .........................................................................

Pump Sampling .............................................................................................................

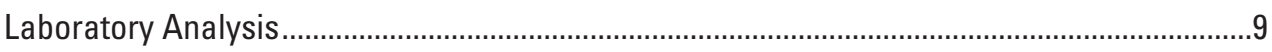

Quality Assurance and Quality Control .............................................................................

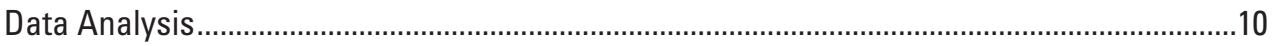

Results of Passive and Pumped Sampling ...............................................................................

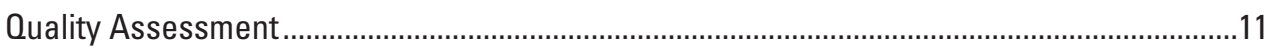

Major Ions and Trace Elements....................................................................................11

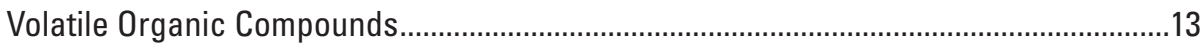

Comparison of Results from Passive and Pumped Sampling Methods .................................14

Relative Percent Difference Between Sampling Methods................................................14

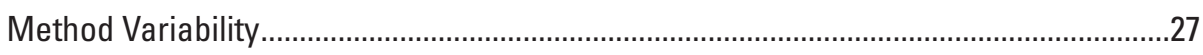

Potential Reasons for Differences Between Passive and Pump Samples .....................28

Determination of Optimal Sampling Depth ......................................................................

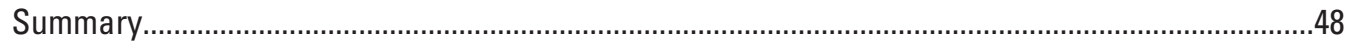

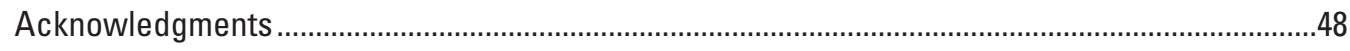

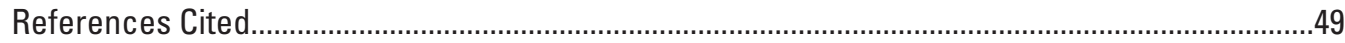

\section{Figures}

1. Map showing locations of water-supply wells, sentinel well nests, the Bulk Fuels Facility, and the ethylene dibromide plume (2019 and 2020), Kirtland Air Force Base, southern Albuquerque, New Mexico.

2. Schematic diagram showing the generalized nested well construction and locations of the screened intervals in relation to the shallow, middle, and deep axial-fluvial deposits and $\mathrm{A} 1$ and $\mathrm{A} 2$ clay units and a well screened across the water table

3. Photograph showing a dual-membrane passive diffusion bag sampler and a diagram showing membrane construction. 
4. Photograph showing dual-membrane passive diffusion bag sampler retrieval at Veteran's Administration well site, Kirtland Air Force Base, Albuquerque, New Mexico ....

5. Boxplots showing volatile organic compound data by analyte for environmental and quality-control samples associated with passive samplers in sentinel wells, Kirtland Air Force Base, Albuquerque, New Mexico, November 2018April 2019

6. Graphs showing passive sampling method concentrations versus pump sampling method concentrations for major ions for sentinel wells CC-1A, SO-1A, TR-1A, and VA-1A at and near Kirtland Air Force Base, Albuquerque, New Mexico

7. Graphs showing passive sampling method concentrations versus pump sampling method concentrations for trace elements for sentinel wells CC-1A, SO-1A, TR-1A, and VA-1A at and near Kirtland Air Force Base, Albuquerque, New Mexico

8. Graphs showing vertical profile of major ion and stable isotope concentrations and trace element concentrations in passive and pump samples, including method variability, at CC-1A near Kirtland Air Force Base, Albuquerque, New Mexico

9. Graphs showing vertical profile of major ion and stable isotope concentrations and trace element concentrations in passive and pump samples, including method variability, at SO-1A

10. Graphs showing vertical profile of major ion and stable isotope concentrations and trace element concentrations in passive and pump samples, including method variability, at TR-1A

11. Graphs showing vertical profile of major ion and stable isotope concentrations and trace element concentrations in passive and pump samples, including method variability, at VA-1A

12. Photographs showing samplers retrieved from VA-1A that have black precipitate on the outsides and filter from VA-1A, where black precipitate formed in the processing filter

13. Eh-pH diagram of the system Manganese-Oxygen-Hydrogen with $\mathrm{pH}$ values from the TR-1A and VA-1A passive and pumped samples

14. Graphs showing concentrations of selected trace elements from historical quarterly sampling using the pump method for TR-1A, CC-1A, and S0-1A, Kirtland Air Force Base, Albuquerque, New Mexico

15. Vertical sampling profile at CC-1A showing the screened interval in which the passive samplers were placed and results of relative percent difference analysis, the results of geophysical logging, and the lithology, Kirtland Air Force Base, Albuquerque, New Mexico

16. Vertical sampling profile at SO-1A showing the screened interval in which the passive samplers were placed and results of relative percent difference analysis, the results of geophysical logging, and the lithology, Kirtland Air Force Base, Albuquerque, New Mexico

17. Vertical sampling profile at TR-1A showing the screened interval in which the passive samplers were placed and results of relative percent difference analysis, the results of geophysical logging, and the lithology, Kirtland Air Force Base, Albuquerque, New Mexico

18. Vertical sampling profile at VA-1A showing the screened interval in which the passive samplers were placed and results of relative percent difference analysis, the results of geophysical logging, and the lithology, Kirtland Air Force Base, Albuquerque, New Mexico 


\section{Tables}

1. Site and vertical profiling information for selected sentinel wells at and near Kirtland Air Force Base, Albuquerque, New Mexico, $2019 .$.

2. Analysis results for source, equipment, and field inorganic blanks with major ion or trace element detections above the detection limit for sentinel wells at and near Kirtland Air Force Base, Albuquerque, New Mexico

3. Results of inorganic replicate variability analysis for pump and passive sampling methods at sentinel wells at and near Kirtland Air Force Base, Albuquerque, New Mexico

4. Volatile organic compounds detected in environmental and quality-control samples collected from passive samplers in sentinel wells at and near Kirtland Air Force Base, Albuquerque, New Mexico, November 2018 to April 2019.

5. Relative percent difference between pump and passive sampling results at sentinel well CC-1A near Kirtland Air Force Base, Albuquerque, New Mexico..

6. Relative percent difference between pump and passive sampling results at sentinel well SO-1A near Kirtland Air Force Base, Albuquerque, New Mexico..............22

7. Relative percent difference between pump and passive sampling results at sentinel well TR-1A near Kirtland Air Force Base, Albuquerque, New Mexico

8. Relative percent difference between pump and passive sampling results at sentinel well VA-1A, Kirtland Air Force Base, Albuquerque, New Mexico

9. Redox process assignments of pump sampling results at sentinel wells at and near Kirtland Air Force Base, Albuquerque, New Mexico, April 2019. 


\section{Conversion Factors}

U.S. customary units to International System of Units

\begin{tabular}{|c|c|c|}
\hline Multiply & By & To obtain \\
\hline \multicolumn{3}{|c|}{ Length } \\
\hline inch (in.) & 2.54 & centimeter $(\mathrm{cm})$ \\
\hline inch (in.) & 25.4 & millimeter $(\mathrm{mm})$ \\
\hline foot $(\mathrm{ft})$ & 0.3048 & meter $(\mathrm{m})$ \\
\hline mile (mi) & 1.609 & kilometer $(\mathrm{km})$ \\
\hline \multicolumn{3}{|c|}{ Area } \\
\hline square mile $\left(\mathrm{mi}^{2}\right)$ & 259.0 & hectare (ha) \\
\hline square mile $\left(\mathrm{mi}^{2}\right)$ & 2.590 & square kilometer $\left(\mathrm{km}^{2}\right)$ \\
\hline \multicolumn{3}{|c|}{ Volume } \\
\hline ounce, fluid (fl. oz) & 0.02957 & liter (L) \\
\hline pint (pt) & 0.4732 & liter (L) \\
\hline quart (qt) & 0.9464 & liter (L) \\
\hline gallon (gal) & 3.785 & liter (L) \\
\hline gallon (gal) & 3,785 & milliliter $(\mathrm{mL})$ \\
\hline \multicolumn{3}{|c|}{ Flow rate } \\
\hline foot per minute (ft/min) & 0.3048 & meter per minute (m/min) \\
\hline gallon per minute (gal/min) & 0.06309 & liter per second $(\mathrm{L} / \mathrm{s})$ \\
\hline gallon per minute (gal/min) & 3.785 & liter per minute $(\mathrm{L} / \mathrm{min})$ \\
\hline \multicolumn{3}{|c|}{ Mass } \\
\hline ounce, avoirdupois (oz) & 28.35 & $\operatorname{gram}(\mathrm{g})$ \\
\hline pound, avoirdupois (lb) & 0.4536 & kilogram (kg) \\
\hline
\end{tabular}

International System of Units to U.S. customary units

\begin{tabular}{|c|c|c|}
\hline Multiply & By & To obtain \\
\hline \multicolumn{3}{|c|}{ Length } \\
\hline centimeter $(\mathrm{cm})$ & 0.3937 & inch (in.) \\
\hline millimeter $(\mathrm{mm})$ & 0.03937 & inch (in.) \\
\hline meter $(\mathrm{m})$ & 3.281 & foot $(\mathrm{ft})$ \\
\hline kilometer (km) & 0.6214 & mile (mi) \\
\hline meter $(\mathrm{m})$ & 1.094 & yard (yd) \\
\hline \multicolumn{3}{|c|}{ Volume } \\
\hline liter $(\mathrm{L})$ & 33.81402 & ounce, fluid (fl. oz) \\
\hline liter $(\mathrm{L})$ & 2.113 & pint $(p t)$ \\
\hline liter $(\mathrm{L})$ & 1.057 & quart (qt) \\
\hline liter (L) & 0.2642 & gallon (gal) \\
\hline liter $(\mathrm{L})$ & 61.02 & cubic inch $\left(\right.$ in $\left.^{3}\right)$ \\
\hline \multicolumn{3}{|c|}{ Mass } \\
\hline $\operatorname{gram}(\mathrm{g})$ & 0.03527 & ounce, avoirdupois (oz) \\
\hline kilogram (kg) & 2.205 & pound avoirdupois (lb) \\
\hline
\end{tabular}

Temperature in degrees Celsius $\left({ }^{\circ} \mathrm{C}\right)$ may be converted to degrees Fahrenheit $\left({ }^{\circ} \mathrm{F}\right)$ as follows:

${ }^{\circ} \mathrm{F}=\left(1.8 \times{ }^{\circ} \mathrm{C}\right)+32$. 


\section{Datum}

Horizontal coordinate information is referenced to the North American Datum of 1983 (NAD 83).

\section{Supplemental Information}

Concentrations of chemical constituents in water are given in either milligrams per liter (mg/L) or micrograms per liter ( $\mu \mathrm{g} / \mathrm{L})$.

Stable isotope ratios $\left(\delta^{18} 0\right.$ and $\left.\delta^{2} H\right)$ are reported in per mil (parts per thousand) relative to Vienna Standard Mean Ocean Water.

\section{Abbreviations}

$\begin{array}{ll}\delta^{2 H} & \text { stable isotope of hydrogen } \\ \delta^{180} & \text { stable isotope of oxygen } \\ \text { ABCWUA } & \text { Albuquerque Bernalillo County Water Utility Authority } \\ \text { BFF } & \text { Bulk Fuels Facility } \\ \text { bls } & \text { below land surface } \\ \text { EDB } & \text { ethylene dibromide } \\ \text { EPA } & \text { U.S. Environmental Protection Agency } \\ \text { IBW } & \text { inorganic blank water } \\ \text { KAFB } & \text { Kirtland Air Force Base } \\ \text { LRL } & \text { laboratory reporting level } \\ \text { NADA } & \text { Nondetects and Data Analysis (software package) } \\ \text { NMWSC } & \text { New Mexico Water Science Center (USGS) } \\ \text { NWOL } & \text { National Water Quality Laboratory (USGS) } \\ \text { OBW } & \text { organic blank water } \\ \text { RPD } & \text { relative percent difference } \\ \text { USACE } & \text { U.S. Army Corps of Engineers } \\ \text { USGS } & \text { U.S. Geological Survey } \\ \text { VA } & \text { Veteran's Administration } \\ \text { VOC } & \text { volatile organic compound } \\ \text { VPBW } & \text { volatile/pesticide-grade water } \\ & \end{array}$





\title{
Comparison of Passive and Pumped Sampling Methods for Analysis of Groundwater Quality, Kirtland Air Force Base, Albuquerque, New Mexico, 2019
}

\author{
By Rebecca E. Travis and Kate Wilkins
}

\section{Abstract}

A plume of ethylene dibromide (EDB) dissolved in groundwater extends northeast from the Bulk Fuels Facility on Kirtland Air Force Base, New Mexico. The leading edge of the EDB plume is upgradient from several water-supply wells. In 2013, the U.S. Geological Survey (USGS), in cooperation with the Albuquerque Bernalillo County Water Utility Authority and the U.S. Air Force, installed four sentinel well nests and two aquifer-test pumping wells between the EDB plume and the water-supply wells to serve as an early warning if the plume travels toward the water-supply wells. Since 2015, the USGS has used submersible pumps to sample the sentinel wells quarterly. In February 2017, the USGS began using dual-membrane passive diffusion bag samplers for quarterly sampling in the wells. To ensure that the passive samplers are obtaining representative samples of the groundwater contaminants, the USGS, in cooperation with the U.S. Air Force, initiated a study in 2019 to compare results from pump sampling and passive samplers and to use vertical profiling to determine the optimal depth for passive sampler placement in the screened interval to better inform long-term monitoring of the site.

Vertical profiling included deploying passive samplers throughout the submerged screened interval of four shallow sentinel wells. After retrieval of the passive samplers, pump samples were collected. The results of analyses of both types of samples were compared. Volatile organic compound results for this study were all below the raised reporting levels, which is a level five times the maximum concentration detected in a blank and determined by an in-depth quality assessment; therefore, this study focused on inorganic constituent results, including major ions, trace elements, and stable isotopes of water, to calculate the relative percent difference (RPD) between the pump and passive sampling method results as a way to determine where passive samplers would be best placed in each of the wells. Several analytes had an RPD of more than plus or minus 50 percent, and several analytes were not within the estimated variability for each sampling method. Additionally, the variability within each sampling method was quantified and compared. Factors that likely contributed to the lack of comparison between each sampling method included temporal variability, flow regime, volume of sample integrated through different aquifer intervals, and reduction/oxidation processes. RPD and method variability were used to determine the intervals within each well with the greatest agreement between sampling methods. Optimal sampling depths for each well were then correlated to the intervals where quarterly sampling has been occurring.

\section{Introduction}

Kirtland Air Force Base (KAFB) is located south of Albuquerque, New Mexico, in Bernalillo County, and a Bulk Fuels Facility (BFF) is in the north-central portion of KAFB (fig. 1). Leaks in an underground pipe used to transfer aviation fuels at the KAFB BFF were discovered in 1999 during pipeline pressure testing (U.S. Air Force, 2011). The BFF has been used for fuel transfer and storage since 1953, but the exact date when the pipes began leaking is unknown (U.S. Army Corps of Engineers [USACE], 2017). An unknown amount of leaked fuel reached the water table and has since migrated northeast of KAFB (fig. 1). The aviation fuel additive ethylene dibromide (EDB) is the main contaminant of concern, which has a U.S. Environmental Protection Agency (EPA) drinking water maximum contaminant level of 0.05 microgram per liter $(\mu \mathrm{g} / \mathrm{L} ; \mathrm{EPA}, 2020)$. Other contaminants of concern include the more common fuel contaminants benzene, toluene, ethyl benzene, and xylenes. In 2010, the New Mexico Environment Department issued a Resource Conservation and Recovery Act permit to oversee cleanup of the contaminant plume (New Mexico Environment Department, 2010).

The most laterally extensive fuel contaminant, EDB, has moved parallel to the mapped groundwater flow direction and has formed a plume that, as of June 2019, extended about 3,300 feet (ft) northeast from the BFF area (USACE, 2019). The leading edge of the EDB plume (defined as the $0.05 \mu \mathrm{g} / \mathrm{L}$ concentration contour) was about 5,600 ft from the nearest downgradient Albuquerque Bernalillo County Water Utility Authority (ABCWUA) water-supply wells (fig. 1; USACE, 2019). The size and location of the plume are continually 


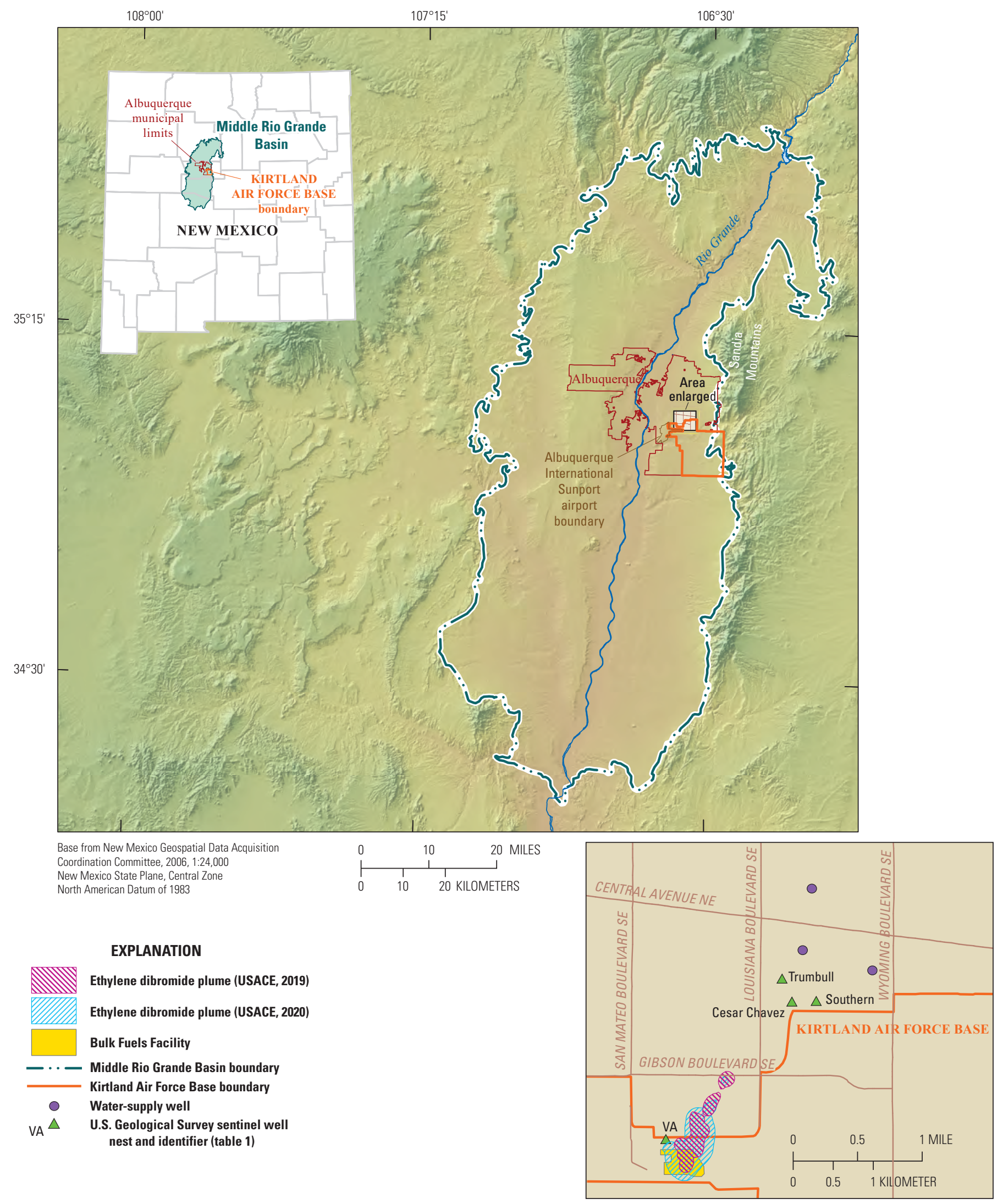

Figure 1. Locations of water-supply wells, sentinel well nests, the Bulk Fuels Facility, and the ethylene dibromide plume (2019 and 2020), Kirtland Air Force Base, southern Albuquerque, New Mexico. [USACE, U.S. Army Corps of Engineers] 
changing because of treatment occurring at KAFB; by 2020, the plume extended about 2,100 ft northeast from the BFF. The plume is studied and mapped by Air Force Civil Engineer Center contractors (USACE, 2020).

In 2013, the ABCWUA requested that the U.S. Geological Survey (USGS) install a nest of sentinel wells between the plume and the ABCWUA water-supply wells (Trumbull, fig. 1) because of concerns about possible contamination reaching Albuquerque's water supply. The purpose of the sentinel wells is to provide early warning of EDB plume migration towards water-supply wells. In 2014, the USGS began a cooperative project with the U.S. Air Force through the Air Force Civil Engineer Center to drill additional sentinel wells at the Southern and Cesar Chavez well sites, and in 2016, at the Veteran's Administration (VA) well site (fig. 1).

The sentinel wells have been sampled quarterly by the USGS since 2015 for inorganic and organic constituents. Until February 2017, the wells were sampled by using a volumetric-purge pump sampling method (hereinafter referred to as "pump sampling"), using dedicated submersible pumps installed in the wells. Samples were collected after three well casing volumes of groundwater were purged and field properties ( $\mathrm{pH}$, water temperature, and specific conductance) in the purged water were stabilized (USGS, variously dated). Continued pump sampling for the sentinel wells was determined to be unsustainable due to the total depth of the wells, the large volume of investigation-derived wastewater created by the pump sampling method, and failing pumps. In 2017, the USGS began using dual-membrane passive diffusion samplers (hereinafter referred to as "passive samplers"), which eliminated the need to manage wastewater, decreased the costs associated with materials and labor, and discontinued the use of corroded pumps or generators. To ensure that the passive samplers are obtaining representative water chemistry samples, the USGS, in cooperation with the U.S. Air Force, initiated a study in 2019 to compare results from pump sampling and passive samplers and to determine the optimal depth for passive sampler placement in the screened interval to better inform long-term monitoring of the site.

\section{Purpose and Scope}

This report compares the chemistry of groundwater samples obtained by using two different sampling methods (pump and passive) for four sentinel wells near KAFB and describes the vertical variability of water quality in the deep groundwater wells. The discrete interval that is the most representative location for the passive samplers to provide comparable results to historical pump sampling was determined. Results of this study will help determine the sampling depth where the passive sampler would be best placed to obtain representative water chemistry for the sentinel wells.

\section{Description of Study Area}

The Middle Rio Grande Basin (fig. 1) encompasses about 3,060 square miles along the Rio Grande Valley in central New Mexico (Thorn and others, 1993) and is underlain with Cenozoic-age alluvium deposits along the Rio Grande (Bartolino and Cole, 2002). The basin is bound by mountainous areas to the north, east, and south, and by a plateau to the west. The Rio Grande is the largest river in New Mexico and flows from north to south through the basin (Bartolino and Cole, 2002).

\section{Climate}

The climate of the Middle Rio Grande Basin is semiarid (Thorn and others, 1993). From 2015 to 2019, annual precipitation ranged from 6.7 to 11.5 inches (in.) at the Albuquerque International Sunport airport, which is adjacent to KAFB, with most rainfall occurring between July and October (National Oceanic and Atmospheric Administration, 2020). Annual evaporation ranges between 50 and $60 \mathrm{in}$. throughout the basin (Thorn and others, 1993). Large fluctuations in the daily temperature and low humidity are also prevalent (Plummer and others, 2012).

\section{Geology and Hydrology}

The Middle Rio Grande Basin is one of a series of alluvial basins located in the Rio Grande rift valley, and it contains approximately $14,000 \mathrm{ft}$ of alluvial fill in the deepest parts of the basin (Thorn and others, 1993). These sediments are primarily alluvium and colluvium, and the primary aquifer of the Middle Rio Grande Basin is composed of formations of the Santa Fe Group of Oligocene-Pleistocene age. The Santa Fe Group has informally been subdivided into lower, middle, and upper lithostratigraphic units based on lithology and age (Hawley and others, 1995; Connell and others, 1998). In the study area, the upper Santa Fe Group is composed primarily of the Sierra Ladrones Formation that informally has been subdivided into piedmont (QTsp) and axial-fluvial (QTsp) facies (Connell and others, 1998).

The upper member of the Sierra Ladrones Formation is a piedmont facies (QTsp) that interfingers onto the lower member of the axial-fluvial facies (QTsp); the depositional environment for the QTsp is generally interpreted as alluvial fan. The piedmont facies (QTsp) is composed of poorly consolidated red to yellowish-brown conglomerate and sandstone with minor mudstone (Connell, 2006). The lower member of the Sierra Ladrones Formation is typically associated with axial-fluvial deposits of the ancestral Rio Grande. The axialfluvial facies (QTsp) is pebbly to cobbly gray to yellowishbrown sand with interbedded mud (Connell, 2006). The QTsp deposits are generally considered to be the most productive water-bearing deposits in the basin. 
QTsa is interbedded with two distinct layers, identified by Connell and others (1998) as sand and silt-clay sequences, and was observed to be primarily clay and silt-clay in the study area (Bell and others, 2018). The two layers are present throughout the study area and generally act as confining units, separating QTsa into three distinct water-bearing units (Myers and Friesz, 2019). The confining units will be referred to in this report as "A1" and "A2," and the top of each unit is located at approximately 1,170 and $817 \mathrm{ft}$ below land surface (bls), respectively (Myers and Friesz, 2019).

Regional groundwater flow in the upper Santa Fe Group is generally southward. In southeast Albuquerque, however, the local groundwater flow direction is affected by pumping from water-supply wells, and currently (2021), groundwater flows northeastward (Powell and McKean, 2014). Recharge occurs locally through seepage from the Rio Grande to the west of KAFB and by mountain-front recharge along the Sandia Mountains to the east (Plummer and others, 2012). Changes in water resource management have resulted in a groundwater-level rebound in the study area since 2008 (Galanter and Curry, 2019). Depth to groundwater in the study area is about $500 \mathrm{ft}$ bls.

\section{Previous Investigations}

Several hydrogeological and geochemical investigations have taken place at the KAFB sentinel wells and the surrounding area, including in the Middle Rio Grande Basin. KAFB has conducted extensive investigations around the area of the BFF and EDB plume, including a comparison of the dualmembrane passive diffusion bag sampler and low-flow purge sampling.

\section{Studies Within the KAFB and Sentinel Well Area}

Several studies related to the presence of the EDB plumes have been conducted in the area of the sentinel wells. Wellbore flow logging (Travis and Myers, 2019) was conducted on two pumping wells, located at the Southern and Cesar Chavez nests (fig. 1). The results from that study indicated that the most productive interval was the deepest QTsa interval below the lowermost clay unit (A1 unit), which produced more than 60 percent of groundwater flow to the wells. The interval between the A1 and A2 units was the second most productive interval. Travis and Myers (2019) and Myers and Friesz (2019) demonstrated that there is an upwardly directed vertical groundwater-flow gradient in the deeper sentinel wells, driven by the confining clay units and recharge sources present in the study area. However, the vertical gradient was not present in the shallowest sentinel wells, which were not confined by clay units. These findings are consistent with Bexfield and Anderholm (2002), who investigated water levels in deep nested piezometers in the Albuquerque area and found that in piezometer nests located east of the Rio Grande, vertical gradients were directed primarily upward.

\section{Passive Sampling Studies}

The dual-membrane passive diffusion bag sampler is relatively new equipment for groundwater sampling. The sampler is an equilibrium-membrane-type passive sampler, and it combines two different membranes. The sampler has been shown to obtain representative groundwater samples for major cations and anions, trace metals, nutrients, and volatile organic compounds (VOCs; EON Products, Inc., 2021). Advantages of using the sampler include limited investigation-derived wastewater and construction materials that do not degrade and are disposable. These advantages enable samplers to be deployed in a well from one sampling event to the next and reduce the need for equipment decontamination (Imbrigiotta and Harte, 2020).

In 2014, EON Products, Inc. (2021), in cooperation with EPA Region 6 and EA Engineering, conducted two rounds of sampling at a metal plating facility, where hexavalent chromium was the primary contaminant of concern and wells were 100-140 ft deep, to compare low-flow pump sampling and dual-membrane passive diffusion bag samplers for analysis of inorganic major ions and trace element concentrations. The low-flow pump sampling uses a pump with a reduced discharge capacity, typically $0.1-0.5$ liter per minute (or $0.03-0.13$ gallon per minute $[\mathrm{gal} / \mathrm{min}]$ ), that does not fully purge the well volume (ASTM International, 2018). The results from the study indicate that the two sampling methods were comparable except for some analytes, including chromium, iron, lithium, and zinc, with greater than 20 percent relative percent difference (RPD), a study-specific threshold. Aluminum, copper, manganese, sulfate, and vanadium had between 10 and 20 percent RPD. Organic compounds that exceeded 20 percent RPD included 1,2-dichlorobenzene, 4-bromofluorobenzene, cyclohexane, meta-xylene, paraxylene, and tetrachloroethene.

In 2016, an evaluation of the passive sampler was conducted in wells at KAFB within the EDB plume by EA Engineering on behalf of the Air Force Civil Engineer Center. Low-flow sampling results were compared to passive sampler results at depths similar to those of the shallow USGS sentinel wells. Even though the focus of the sampling and analysis was on VOCs and EDB, results indicated that dissolved iron and manganese concentrations were typically lower in the passive samples than in the pumped samples. Benzene and EDB concentrations were found to be comparable between the two methods. Most of the inorganic data had acceptable RPDs (with a threshold of 35 percent specific to this study) between the two sampling methods (USACE, 2016). The passive sampler was used at KAFB to assess the BFF plume after this evaluation (USACE, 2016). 


\section{Methods}

For this study, 56 groundwater samples were collected from wells in the four sentinel well nests (figs. 1 and 2) in April 2019 for water-quality analysis. The KAFB sentinel wells were constructed as a group of four nested wells such that each well screen was within one of the distinct waterbearing units; the samples were collected from depths near or at the water table (fig. 2). The shallow and water table wells are located above the A2 unit in the upper QTsa. The middle well is installed below the A2 unit and above the A1 unit in the middle QTsa deposits, and the deep well is installed below the A1 unit in the deep QTsa deposits.

Two different methods were used for sample collection in all four wells. The four sampled wells were Cesar Chavez Well A (CC-1A), Southern Sentinel Well A (SO-1A), Trumbull Sentinel Well A (TR-1A), and VA Sentinel Well A (VA-1A). Table 1 provides USGS site and well information, in addition to deployment dates of passive samplers, pertinent water levels, number of passive samplers per well, and sampling dates of passive samplers and pump sampling. Dual-membrane passive diffusion bag samplers (passive samplers) were used to collect 52 of the samples, and dedicated submersible pumps were used to collect 4 samples. The passive samplers were deployed in late February 2019 and were retrieved in early April 2019. The day after the samplers were retrieved, a dedicated portable Bennett pump was lowered into the well and used for pumped sampling. All the groundwater samples from the wells were analyzed for VOCs, major inorganic constituents, trace elements, alkalinity, and stable isotopes of oxygen $\left(\delta^{18} \mathrm{O}\right)$ and hydrogen $\left(\delta^{2} \mathrm{H}\right)$. Waterquality data are publicly available from the USGS National Water Information System (USGS, 2019) using the site identification numbers in table 1.

\section{Water-Quality Sampling}

Water-quality sampling was completed by using two different methods. Passive sampling used dualmembrane passive diffusion bag samplers. Pump sampling used the volumetric purge method with submersible pumps.

\section{Passive Sampling}

Passive sampling was used to complete the vertical profiling of the wells. This method is described here because it varies from methods in the USGS National Field Manual (USGS, variously dated).

\section{Dual-Membrane Passive Diffusion Bag Sampler}

Passive samplers were used to vertically profile the wells. A dual-membrane passive diffusion bag sampler, developed by EON Products, Inc., was used; this sampler consists of a perforated tube with semipermeable membranes on a single sampler (EON Products, Inc., 2021; fig. 3). The hollow, cylindrical, perforated tube is encased with two semipermeable membranes that are in layers to create the dual membrane. The bottom portion of the tube is encased with a low-density polyethylene membrane that acts as a container for the sampled

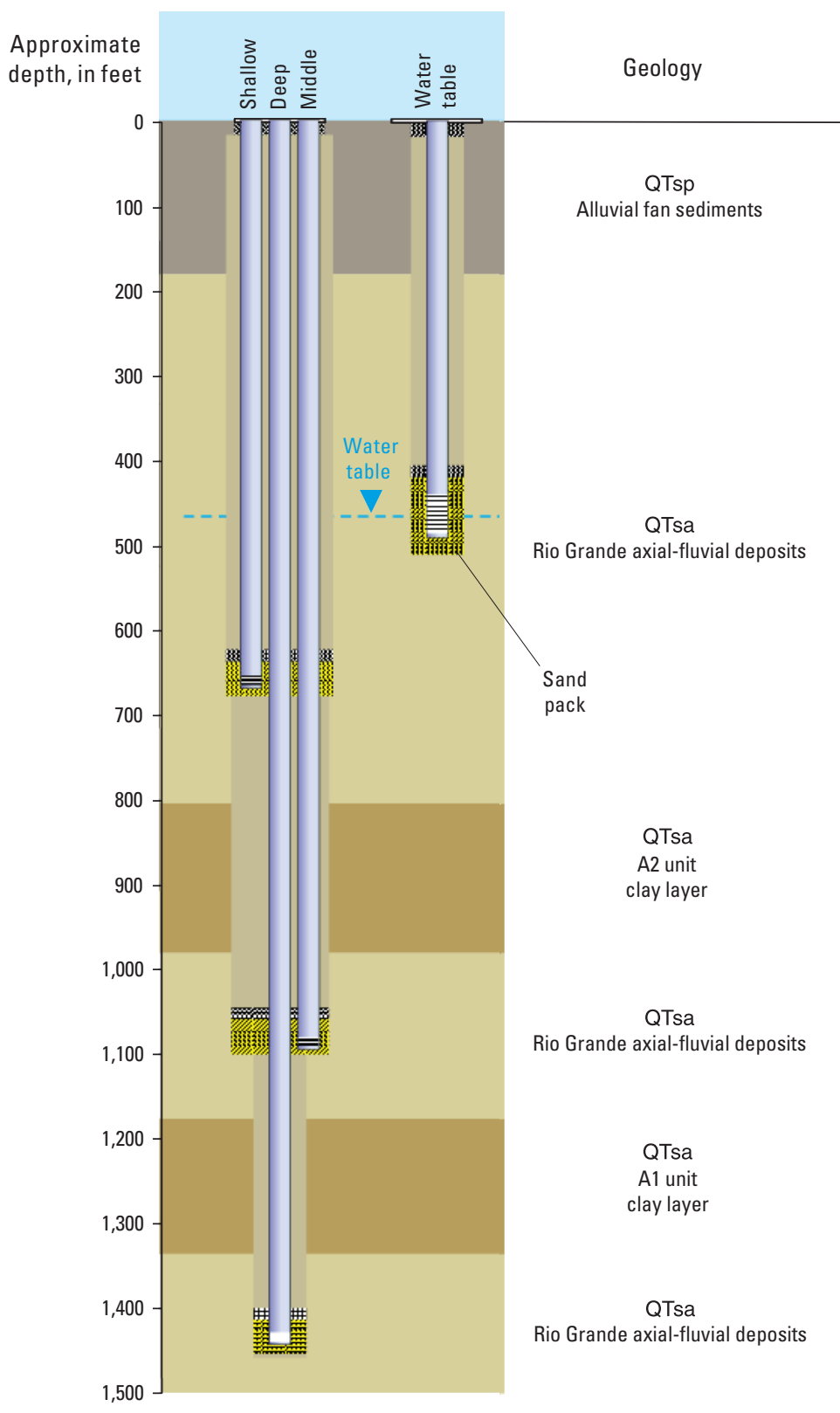

Figure 2. Generalized nested well construction and locations of the screened intervals in relation to the shallow, middle, and deep axial-fluvial deposits and $A 1$ and $A 2$ clay units and a well screened across the water table. 
Table 1. Site and vertical profiling information for selected sentinel wells at and near Kirtland Air Force Base, Albuquerque, New Mexico, 2019.

[USGS, U.S. Geological Survey; ft bls, feet below land surface; in., inch; gal/min, gallon per minute; gal, gallon]

\begin{tabular}{|c|c|c|c|c|c|c|c|c|c|c|c|c|c|c|}
\hline $\begin{array}{l}\text { USGS site identifi- } \\
\text { cation number } \\
\text { (USGS, 2019) }\end{array}$ & Site name & $\begin{array}{l}\text { Well } \\
\text { short } \\
\text { name }\end{array}$ & $\begin{array}{l}\text { Total } \\
\text { well } \\
\text { depth } \\
\text { (ft bls) }\end{array}$ & $\begin{array}{l}\text { Well } \\
\text { diam- } \\
\text { eter } \\
\text { (in.) }\end{array}$ & $\begin{array}{l}\text { Screened } \\
\text { interval } \\
\text { (ft bls) }\end{array}$ & $\begin{array}{c}\text { Passive } \\
\text { sampler } \\
\text { method } \\
\text { deployment } \\
\text { date }\end{array}$ & $\begin{array}{c}\text { Water } \\
\text { level at } \\
\text { deploy- } \\
\text { ment } \\
\text { (ft bls) }\end{array}$ & $\begin{array}{c}\text { Depth } \\
\text { to top } \\
\text { passive } \\
\text { sampler } \\
\text { (ft bls) }\end{array}$ & $\begin{array}{c}\text { Number } \\
\text { of passive } \\
\text { samplers } \\
\text { per well } \\
\text { for } \\
\text { vertical } \\
\text { profile }\end{array}$ & $\begin{array}{l}\text { Passive } \\
\text { sampling } \\
\text { method } \\
\text { retrieval/ } \\
\text { sample } \\
\text { collec- } \\
\text { tion } \\
\text { date } \\
\end{array}$ & $\begin{array}{l}\text { Water } \\
\text { level at } \\
\text { retrieval } \\
\text { (ft bls) }\end{array}$ & $\begin{array}{l}\text { Pump } \\
\text { sampling } \\
\text { method } \\
\text { sample } \\
\text { collection } \\
\text { date }\end{array}$ & $\begin{array}{l}\text { Pumping } \\
\text { rate } \\
\text { (gal/ } \\
\text { min) }\end{array}$ & $\begin{array}{l}\text { Approxi- } \\
\text { mate } \\
\text { volume } \\
\text { purged } \\
\text { (gal) }\end{array}$ \\
\hline 350359106335201 & $\begin{array}{l}\text { Cesar Chavez } \\
\text { Well A }\end{array}$ & $\mathrm{CC}-1 \mathrm{~A}$ & 519 & 2.5 & $459-509$ & $\begin{array}{c}\text { February } 26, \\
2019\end{array}$ & 474.3 & 483.1 & 10 & $\begin{array}{c}\text { April 8, } \\
2019\end{array}$ & 474.16 & $\begin{array}{c}\text { April 9, } \\
2019\end{array}$ & 0.70 & 41 \\
\hline 350359106333901 & $\begin{array}{l}\text { Southern } \\
\text { Sentinel } \\
\text { Well A }\end{array}$ & SO-1A & 538 & 2.5 & $468-518$ & $\begin{array}{c}\text { February } 27, \\
2019\end{array}$ & 1489.9 & 484.7 & 13 & $\begin{array}{c}\text { April 15, } \\
2019\end{array}$ & 486.96 & $\begin{array}{c}\text { April 16, } \\
2019\end{array}$ & 1.00 & 58 \\
\hline 350408106335601 & $\begin{array}{l}\text { Trumbull } \\
\text { Sentinel } \\
\text { Well A }\end{array}$ & TR-1A & 522 & 2.5 & $437-517$ & $\begin{array}{c}\text { February } 25, \\
2019\end{array}$ & 461.0 & 463.2 & 21 & $\begin{array}{c}\text { April 10, } \\
2019\end{array}$ & 460.36 & $\begin{array}{c}\text { April 11, } \\
2019\end{array}$ & 1.10 & 55 \\
\hline 350304106345401 & $\begin{array}{l}\text { VA Sentinel } \\
\text { Well A }\end{array}$ & VA-1A & 660 & 3 & $620-640$ & $\begin{array}{c}\text { February } 28, \\
2019\end{array}$ & 465.2 & 621.0 & 8 & $\begin{array}{c}\text { April 17, } \\
2019\end{array}$ & 464.80 & $\begin{array}{l}\text { April 18, } \\
2019\end{array}$ & 1.25 & 208 \\
\hline
\end{tabular}

${ }^{1}$ Water level is from November 2018. February 2019 water level was rejected in review as misread. 
water and allows for VOC diffusion across the entire length of the polyethylene membrane. The upper portion of the sampler is made of a 125 -micrometer $(\mu \mathrm{m})$ nylon screen membrane to allow inorganic constituents and polar molecules to diffuse into the sampler (Imbrigiotta and Harte, 2020). The upper portion of the dual-membrane sampler does not hold water, but allows ambient groundwater to pass through the upper portion and diffuse vertically within the sampler. Diffusion of inorganic analytes happens at the interface between the two membranes until the concentrations in the sampler have reached equilibrium with the ambient groundwater (EON Products, Inc., 2021). EON Products, Inc., recommends that the passive samplers remain in the well for at least 3 weeks to gain equilibrium with the groundwater and within the sampler. Because the passive samplers preserve dynamic equilibrium, EON states that the passive samplers will represent the analytes and concentrations of the groundwater from the last few days and therefore can remain in the wells indefinitely (EON Products, Inc., 2021).

\section{Field Deployment and Retrieval}

The passive samplers used for vertical profiling analysis were deployed in late February 2019 (table 1). Each sampler was filled with inorganic-grade blank water (IBW) purchased from the USGS National Field Supply Service (https://nwql. usgs.gov/supportservices.shtml). While volatile/pesticidegrade blank water (VPBW) is required for sampling VOCs, USGS analysis of blank water determined that the recycled glass used to house VPBW can leach trace elements into the blank water over time, as documented in the USGS Office of Water Quality Water-Quality Information Note 2006.11 entitled "Field Methods_-Discontinuance of 'Universal'
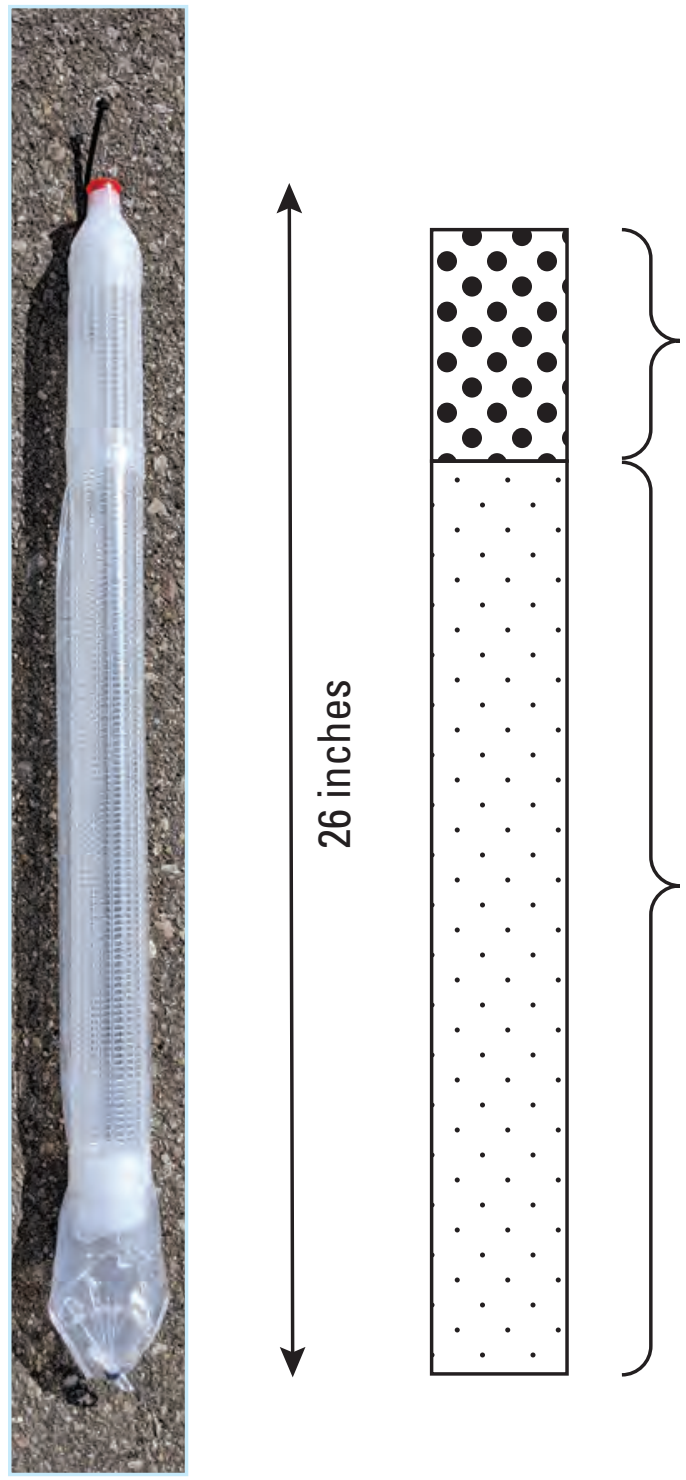

\title{
Large-pore membrane \\ - Permeable to large and small molecules
}

\author{
Small-pore membrane \\ - Permeable to volatile organic compounds \\ - Serves as sample reservoir
}

Figure 3. Dual-membrane passive diffusion bag sampler and a diagram showing membrane construction. 
blank water" (Office of Water Quality, USGS, written commun., 2006). Because trace elements have been discovered in VPBW, each sampler deployed (table 1) was filled with IBW even though VOCs were also collected from each sampler. The samplers were filled from the top with IBW by using a dedicated clean funnel in the water-quality laboratory of the USGS New Mexico Water Science Center (NMWSC). Then, samplers were placed in a clean container that was lined with two clean, virgin, polyethylene bags that had been purchased from the USGS National Field Supply Service. Once all the passive samplers were filled, the clean, virgin, polyethylene bags were tied so that they enclosed the samplers. The samplers were secured in an upright position in the container by placing bubble wrap on the outside of the bags to ensure no spillage occurred when they were transported to the appropriate site. The passive samplers were secured to a dedicated tether with stainless-steel rings that were connected to the top of the passive sampler. The tethers were constructed of polypropylene rope by EON Products, Inc. Samplers were attached to the tether rings at the appropriate depth in the well by using plastic zip ties. Passive samplers are 26 in. long, with 4 in. of space between each sampler. The depth and number of samplers per well depended on the length of the submerged screen interval (table 1).

\section{Passive Sample Field Processing}

Because the passive sampler holds a limited amount of sample water-approximately 630 milliliters $(\mathrm{mL})$ - the standard USGS protocols were modified to accommodate the limited volume of sample water. The USGS National Water Quality Laboratory (NWQL) was consulted prior to the field events to determine the minimum volume needed to run the laboratory analyses. In addition, minimum amounts of sample water were used to condition sample filters and to rinse bottles in the field. In some instances, some analytical results were not obtained because samples were not collected because of loss of sample water by overfilling the sample bottle or spilling from the sampler. The passive samplers were deployed and retrieved by using a battery-operated motorized wench system (fig. 4) that pulled the passive samplers up the well at a slow and constant rate of $25 \mathrm{ft}$ per minute in order to prevent tearing any passive samplers or spilling sample water once the samplers reached the surface.

When the passive samplers reached the surface, they were immediately sampled for VOCs at the field site to limit exposure of the sample to the atmosphere. Because the samplers could be retrieved faster than the VOC samples could be processed, the passive samplers that were waiting to be processed were placed in a clean, virgin, polyethene bag to limit atmospheric exposure and were sampled as soon as possible. The retrieval time and the process time ranged from 2 minutes to 60 minutes, depending on the number of samplers that had been deployed. Samplers were sampled in the order of

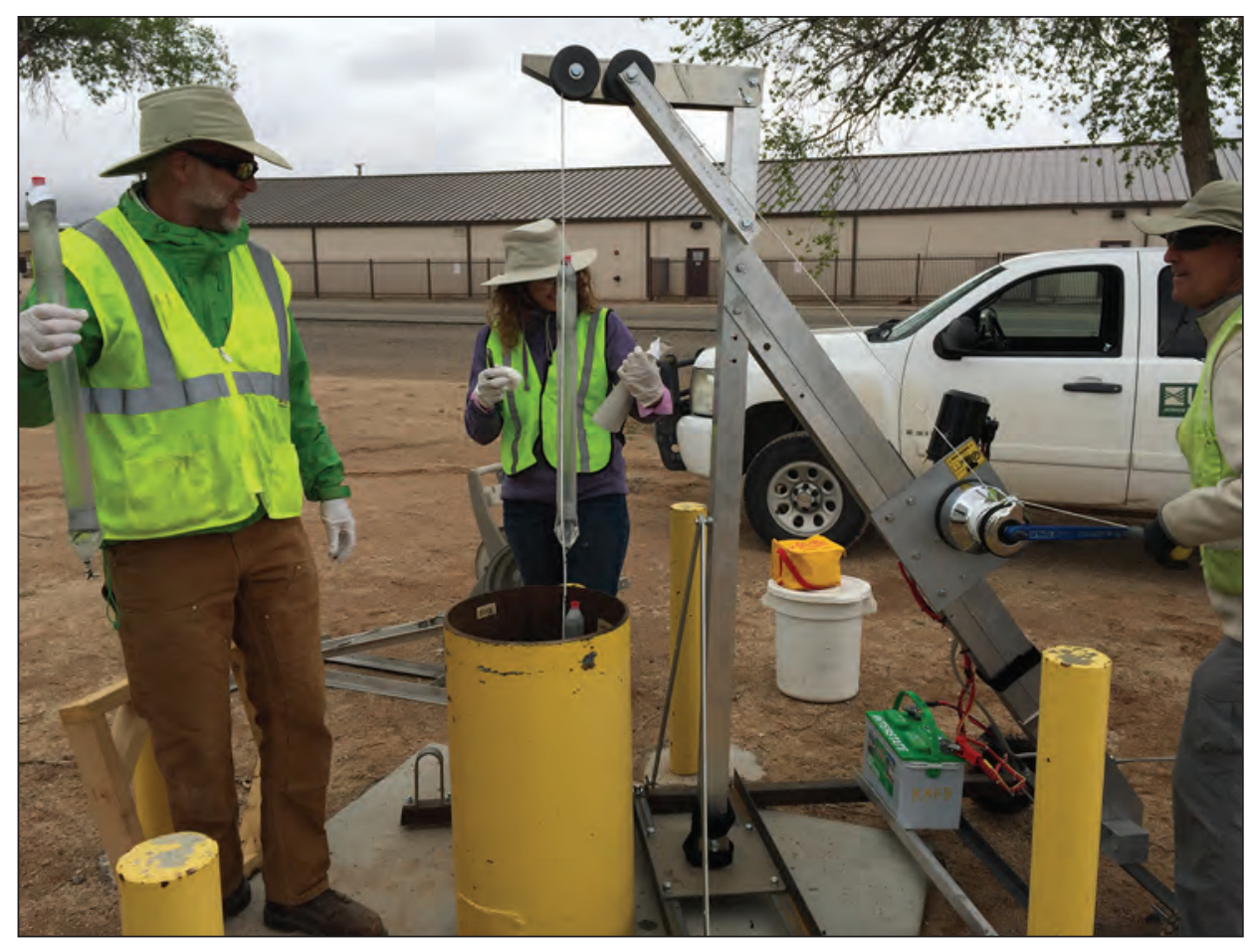

Figure 4. Dual-membrane passive diffusion bag sampler retrieval at Veteran's Administration well site, Kirtland Air Force Base, Albuquerque, New Mexico. 
retrieval, with the first sampler being sampled first. In a well with 21 samplers, the last sampler had a delay in process time because of the limited number of staff onsite. The water in the passive samplers was extracted with a manufacturer-provided straw, which was carefully inserted into the bottom of the passive sampler. For the VOC sample, the unfiltered water flowed through the straw and into two unrinsed $40-\mathrm{mL}$ baked amber glass vials, which were preserved with hydrochloric acid to a $\mathrm{pH}$ less than 2.

Immediately after the VOC sample collection, the remaining unfiltered sample was drained into a dedicated $500-\mathrm{mL}$ field-rinsed polyethylene container. The sample bottles with the remaining unfiltered sample water were chilled until all the VOC samples from the different passive samplers for a given well were collected and processed. Then samples were processed for all inorganic constituents. From the $500-\mathrm{mL}$ container, a $0.45-\mu \mathrm{m}$ disc filter (at CC-1A, SO-1A, and VA-1A) or a larger capacity $0.45-\mu \mathrm{m}$ capsule filter (at TR-1A, because of the presence of precipitate) was used to filter samples to be analyzed for major ions and trace elements (130-mL minimum volume collected). A fresh filter, conditioned with deionized water, was used for each $500-\mathrm{mL}$ polyethylene container; when necessary, filtered samples were acidified with nitric acid to a $\mathrm{pH}$ less than 2 . A filtered sample was collected for determining alkalinity $(75-\mathrm{mL}$ minimum volume collected). Stable isotopes (11-mL minimum volume collected) were collected from the raw (unfiltered) sample, and the remaining raw sample was analyzed for specific conductance and $\mathrm{pH}$, including field-rinsing probes. The alkalinity was titrated at the NMWSC by the incremental equivalence method (USGS, variously dated). All samples except those for the stable isotopes of water were shipped at less than 4 degrees Celsius to the NWQL in Denver, Colorado. Stable isotopes were shipped at room temperature to the USGS Reston Stable Isotope Laboratory in Reston, Virginia.

\section{Pump Sampling}

At each well, water-quality samples were collected with a low volume submersible pump, pumping $0.70-1.25 \mathrm{gal} / \mathrm{min}$ (table 1), following standard protocols set by the USGS National Field Manual (USGS, variously dated). Prior to sampling, the pumps (which were the dedicated pumps removed from the wells prior to passive sampling) were stored in a clean, dedicated area at the NMWSC. The day after the passive samplers were retrieved and sampled, the pump was transported to the field and lowered down the well. The USGS National Field Manual requires removing groundwater equivalent to at least three volumes of the entire well casing and reaching stability of field property values $(\mathrm{pH}$, temperature, specific conductance, turbidity, and dissolved oxygen) before sample collection. The amounts of water purged prior to sampling for each well are listed in table 1. The pump was placed in the middle of the submerged portion of the screened interval of each of the wells, with the exception of VA-1A. The screened interval for VA-1A is $620-640 \mathrm{ft}$ bls, and the tubing length is only $600 \mathrm{ft}$. While the pumps can operate up to 1,000 ft (Bennett Sample Pumps, Inc., 2020), there were issues in the field with tubing collapsing under pressure if the pumps were set at depths greater than $600 \mathrm{ft}$. Therefore, the pump was placed $20 \mathrm{ft}$ above the top of the screen in VA-1A.

Samples collected during the pumping phase were processed according to the USGS National Field Manual (USGS, variously dated). The field properties used for stabilization criteria were collected with a calibrated multiparameter waterquality sonde. Sample processing took place inside of a mobile laboratory to reduce outside contamination. Samples analyzed for VOCs were unfiltered and preserved to a $\mathrm{pH}$ of less than 2 with hydrochloric acid. Major ions, trace element concentrations, and alkalinity were measured in samples filtered with a high-capacity capsule $0.45-\mu \mathrm{m}$ pore size filter. Groundwater collected for analysis of major cations and trace elements was preserved with nitric acid to a $\mathrm{pH}$ of less than 2. Stable isotope ratios in water $\left(\delta^{18} \mathrm{O}\right.$ and $\left.\delta^{2} \mathrm{H}\right)$ and field properties were measured in unfiltered samples. Alkalinity was measured in the field by titration by using the incremental equivalence method (USGS, variously dated). All samples except those to be analyzed for stable isotopes of water were shipped at less than 4 degrees Celsius to the NWQL. Samples for analysis of stable isotopes were shipped at room temperature to the USGS Reston Stable Isotope Laboratory.

\section{Laboratory Analysis}

Water samples were analyzed for VOCs, major ions, and trace elements by the NWQL with gas chromatography/ mass spectrometry using method O-4127-96 (Connor and others, 1998). VOC analysis included these contaminants of concern: benzene, toluene, ethyl benzene, xylene, and EDB. Inductively coupled plasma-mass spectrometry was used for determining the concentration of 22 trace elements (Garbarino, 1999, Garbarino and others, 2005). Ion-exchange chromatography was used to analyze for chlorine, fluorine, and sulfate (Fishman, 1993). Inductively coupled plasma optical emission spectrophotometry was used to analyze for cations, such as calcium, iron, magnesium, potassium, silica, and sodium (Fishman and Friedman, 1989). Major ions are reported in milligrams per liter, and trace elements are reported in micrograms per liter. Stable isotope ratios $\left(\delta^{18} \mathrm{O}\right.$ and $\left.\delta^{2} \mathrm{H}\right)$ were analyzed at the USGS Reston Stable Isotope Laboratory. The isotopes are analyzed by dual-inlet isotope-ratio mass spectrometry (Révész and Coplen, 2008a, b). Stable isotope ratios are reported in per mil relative to Vienna Standard Mean Ocean Water.

\section{Quality Assurance and Quality Control}

Three source, seven equipment, and two field blanks and one replicate pair were collected for this study. Additional historical replicate pairs, from quarterly monitoring, were included for analysis to broaden the pool of data, including 
seven pump method replicate pairs and seven passive method replicate pairs. All quality assurance and control sample collection followed USGS National Field Manual standard protocols (USGS, variously dated). Additional details are provided herein regarding the passive sampler blanks because those methods are not detailed in the USGS National Field Manual.

Source blanks were collected at the NMWSC waterquality laboratory by pouring IBW of the same lot number and source used for deployment, field, or equipment blanks, into the bottles that were used for laboratory analysis. For the passive sampling method, source blanks were collected to test that the IBW and bottles were free of any inorganic constituents. One source blank was collected before deployment of the passive samplers in February 2019 to verify that the water placed within the samplers was free of inorganic and organic constituents. One source blank was collected before retrieval of the passive samplers in April 2019 to verify that the blank water used to collect the field blank was free of inorganic and organic constituents. The third source blank was collected prior to collecting equipment blanks on the pumps in March 2019 to verify that no inorganic or organic constituents were in the blank water used to collect the equipment blanks.

Equipment blanks were collected from the passive samplers at the NMWSC water-quality laboratory by filling the sampler with IBW through a dedicated funnel. The manufacturer-provided straw was inserted into the bag so the water would flow through the straw directly into the sample bottles. This was done to determine if, in general, the passive diffusion bag sampler, funnel, or straw contaminated the IBW. Note that because of the one-time use of the sampler, the passive sampler diffusion bag used for the equipment blank was not deployed in the well. However, because the same manufacturer produced all the passive samplers, it was assumed that every passive sampler was produced in the same way. Only one equipment blank was collected before the deployment of the samplers in February 2019. Because these wells have been sampled quarterly with the passive sampling technique since 2017, historical equipment blank data were used for this analysis of passive samplers in order to provide more data on the passive samplers, which do not have widespread use within the USGS.

For pump sampling, equipment blanks were collected from the four dedicated submersible pumps in March 2019. Each pump was dedicated to an individual well, but the pumps are portable and were removed from the wells when passive sampling was occurring. The pumps were stored at the NMWSC, and the tubing was cleaned by following protocols in the USGS National Field Manual (USGS, variously dated). The entire length of tubing could be used for collection of an equipment blank by placing the pump head in a clean glass cylinder with the appropriate blank water. VPBW was used to collect samples for VOC analysis, and IBW was used to collect samples for inorganic analysis. Three tubing volumes of blank water were needed to decontaminate the pump, an additional three tubing volumes were needed to rinse the pump, and another tubing volume was needed to collect the blank (seven total tubing volumes; USGS, variously dated). Inorganic blanks were collected first, and then organic blanks were collected. This way, the tubing was set up for organic blank collection in the field with fewer volume rinses of VPBW.

An organic field blank and an inorganic field blank were collected from a passive sampler at VA-1A. From the dedicated pumps, an inorganic field blank was collected at CC-1A, and an organic field blank was collected at TR-1A and VA-1A. The field blanks from the passive sampler were collected by pouring IBW into the sampler through a dedicated funnel. A straw was used to dispense water directly into two $40-\mathrm{mL}$ vials for analysis of VOCs, and the remaining water was then poured into a $500-\mathrm{mL}$ bottle through the straw. The $500-\mathrm{mL}$ sample was processed with a filter and analyzed for inorganic analytes. The inorganic field blank from the dedicated pump at CC-1A was collected by using the entire sample line and pump at the field site and was similar to the equipment blank technique, using a clean glass cylinder to hold blank water and the pump head. After flushing the tubing with three volumes of IBW, the inorganic field blanks were filtered and collected. An organic field blank was collected at VA-1A with the same method as at CC-1A, except VPBW was used for sample collection.

Replicate pairs are reported for both sampling methods. The range of dates was expanded outside of this study to include more replicate pairs to increase the pool of data. Even though these samples were collected outside of this study's timeframe, the same collection methods were used as described in this report. Seven sequential replicate pairs were collected by using the pump method from May 2013 through February 2017 and in April 2019. Seven split-replicate pairs were collected by using the passive method from January 2018 through April 2019. Pump method replicates were collected sequentially, immediately after the initial set of samples was collected. Passive sampling replicates were collected by dividing the water sample obtained from a single passive sampler, thus the environmental sample and split-replicate came from the same passive sampler.

\section{Data Analysis}

Because most VOC environmental and blank samples had one or more values at or below a laboratory reporting level (LRL), statistical methods for censored data (Helsel, 2012) were used to analyze the VOCs in this study. Censored data are data having a value reported as less than or greater than a threshold, here, the LRL. Boxplots were created by using the cenboxplot function from the Nondetects and Data Analysis (NADA) software package (Lee, 2015) in the R statistical computing environment (R Core Team, 2015). Boxplots for analytes with censored data were grouped by sample type; percentiles were estimated by using the robust regression order 
statistic method (Helsel, 2012). Outlier data points on boxplots were defined for this study as greater than 1.5 times the interquartile range (fig. 5).

Two data analysis techniques were used to evaluate how the passive sampling results compared to the pump results: RPD and variability between results derived from the two sampling methods. Imbrigiotta and Harte (2020) recommend comparing passive sampling results to the pump sample results by using RPD:

$$
\begin{aligned}
& \mathrm{RPD}=100 \times \\
& \text { (passive sample result - pump sample result) } \\
& \text { (passive sample result }+ \text { pump sample result) } / 2
\end{aligned}
$$

Sample results from this study were evaluated based on RPD criteria from Imbrigiotta and Harte (2020). They suggest that the RPD between passive sample and pump sample results should be within \pm 25 percent for trace metal concentrations greater than $10 \mu \mathrm{g} / \mathrm{L}$ and the RPD should be within \pm 50 percent for trace metal concentrations less than $10 \mu \mathrm{g} / \mathrm{L}$. RPDs for major cations and anions should be within \pm 15 percent because of their higher concentrations. Stable isotopes were evaluated on the basis of an RPD of \pm 15 percent. A negative value is representative of the passive sampler concentration being less than the pump sampler concentration, and positive values are representative of the passive sampler concentration being greater than the pump sampler concentration. RPDs were not calculated for analytes with concentrations below the analytical detection limit.

Major ion and trace element concentrations were compared by using 1-to-1 (1:1) plots of passive sampling results versus pump sampling results. If the concentrations from both methods are similar, the points are on or near the 1:1 line, indicating good agreement between the two methods. Results which diverge from the 1:1 line indicate that the sampling methods are not in agreement and require further investigation. If major ion or trace element results are below the analytical detection limit, they were plotted as one-half the detection limit.

Variability within each sampling method was analyzed by evaluating replicate pairs for each analyte. There were too few replicate pairs to evaluate variability over low and high ranges of concentration, known as the two-range model, as recommended by Mueller and others (2015). In Nowell and others (2013), a study with few replicate pairs, it was determined that using the average relative standard deviation assumes a high variability for lower concentrations because relative standard deviation is used to estimate variability at higher concentrations and calculates a higher relative standard deviation at lower concentrations. While average standard deviation is used to estimate variability at lower concentrations, the standard deviations generally increase proportionally with higher concentrations (Mueller and others, 2015). After evaluating both the average standard and relative standard deviations for both the passive and pump method replicate pairs, the average standard deviation was determined to be the more conservative of the two estimates for this study. Once the variability of each method was calculated for each analyte, the passive sampling results were determined to be within or outside of both the variability of the passive sampling method and the method variability for the pump samples.

Data analysis was limited to field properties, stable isotopes, major ions, and trace elements. VOCs, including EDB, were not found in the majority of samples and were not included in the evaluation. Additional information about the evaluation of low-level VOC detections in the environmental samples is in the "Results of Passive and Pumping Sampling" section under "Quality Assessment."

\section{Results of Passive and Pumped Sampling}

This section of the report first describes the quality assessment using quality assurance samples collected for this and previous studies. The comparison between passive and pumped sampling methods is described, including potential reasons for differences between methods. Determination of the optimal sampling depth for the passive samplers also is described.

\section{Quality Assessment}

The quality assessment for blank and replicate samples are described for major ions and trace elements separate from those for VOCs. The assessment of replicates for stable isotopes are included with the major ions and trace elements.

\section{Major lons and Trace Elements}

The numbers of source solution, equipment, and field inorganic blanks with major ion or trace element detections above the detection limit are reported by analyte in table 2 . If an analyte discussed in this report is not listed in table 2, it was not detected in the blanks. A concentration for threshold of influence was established at 10 times the greatest blank concentration (EPA, 1989, pages 5-16 and 5-17). Environmental samples collected with the pump method were evaluated against all source blanks, pump equipment blanks, and pump field blanks. Environmental samples collected with the passive samplers were evaluated against all source blanks, passive sampler equipment blanks, and passive sampler field blanks. All environmental sample concentrations collected with the pump method were greater than the threshold of influence, except manganese and nickel. All environmental sample concentrations collected with the passive samplers were greater than the threshold of influence, except copper. Thresholds were applied to the pump method samples for manganese and nickel and to the passive method samples for copper. 


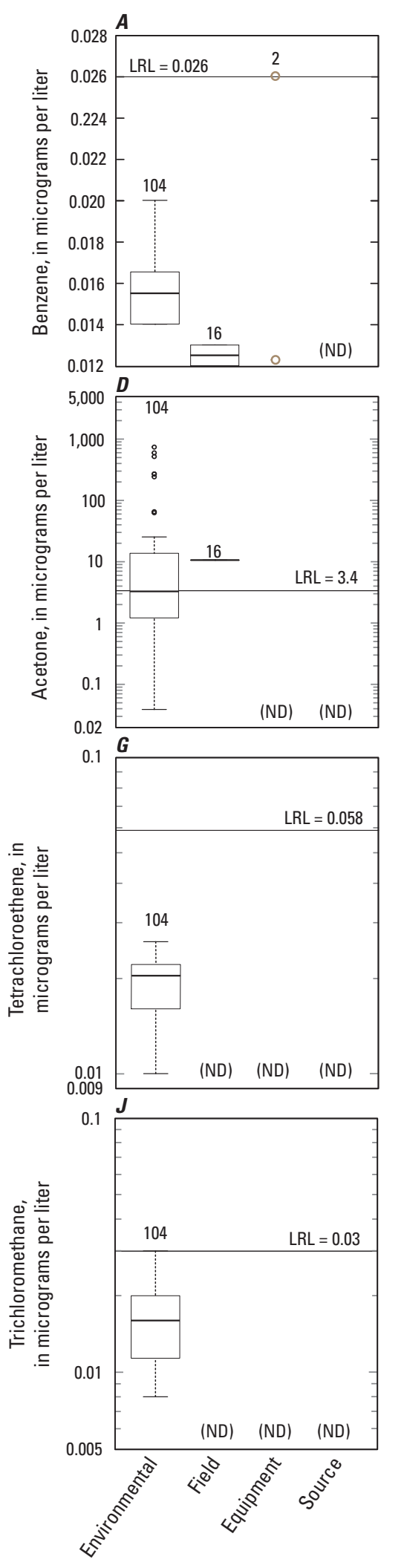

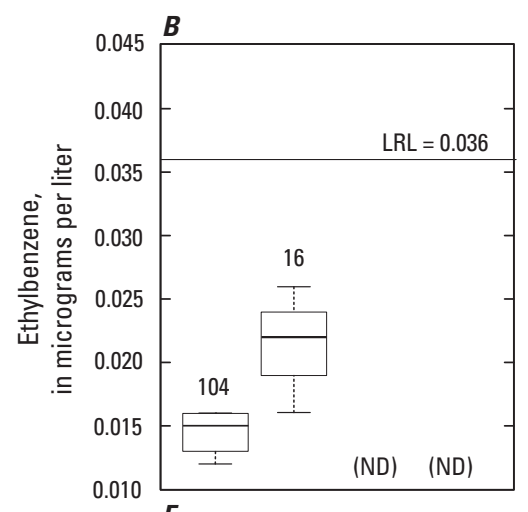
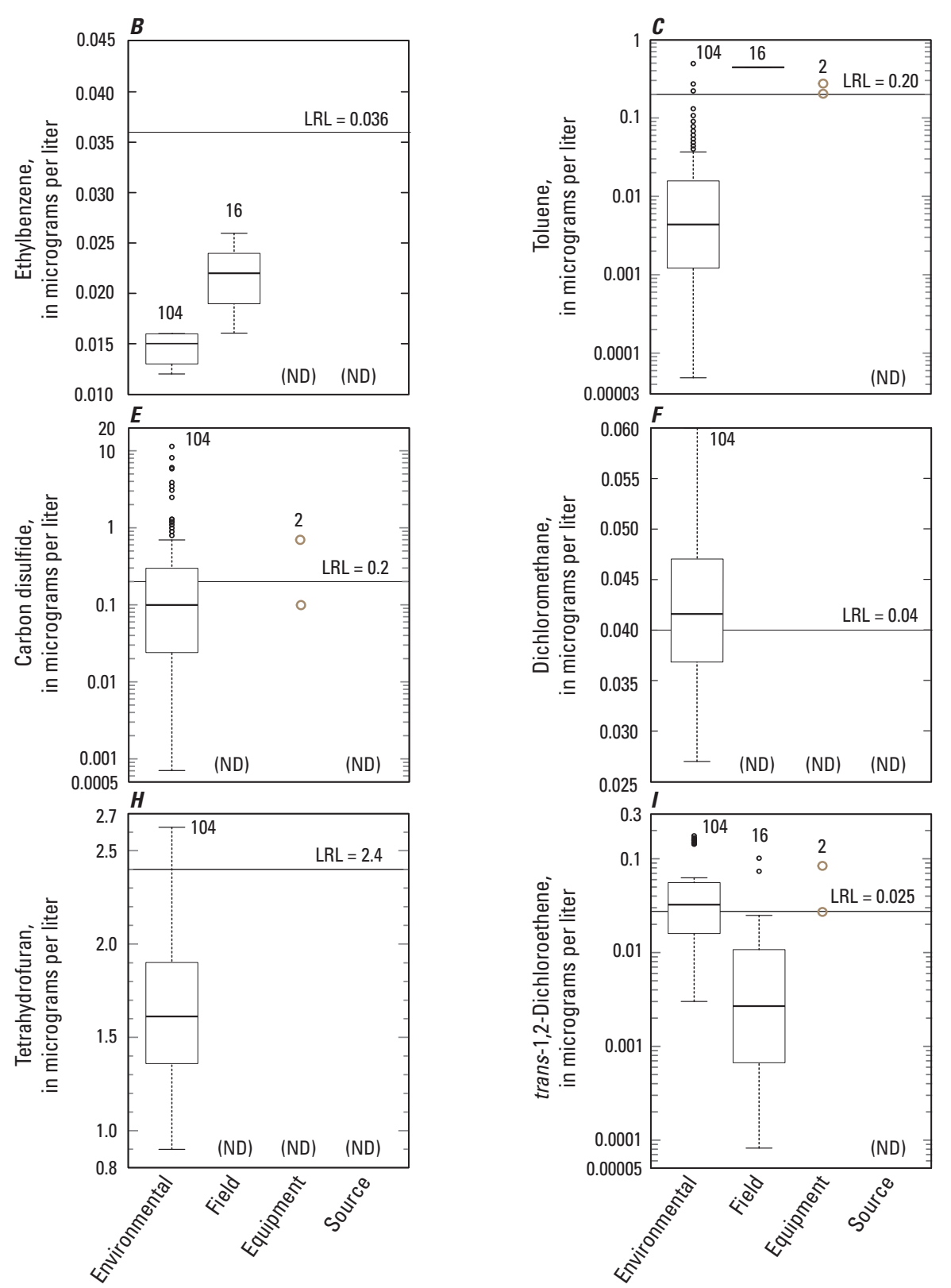

\section{EXPLANATION}

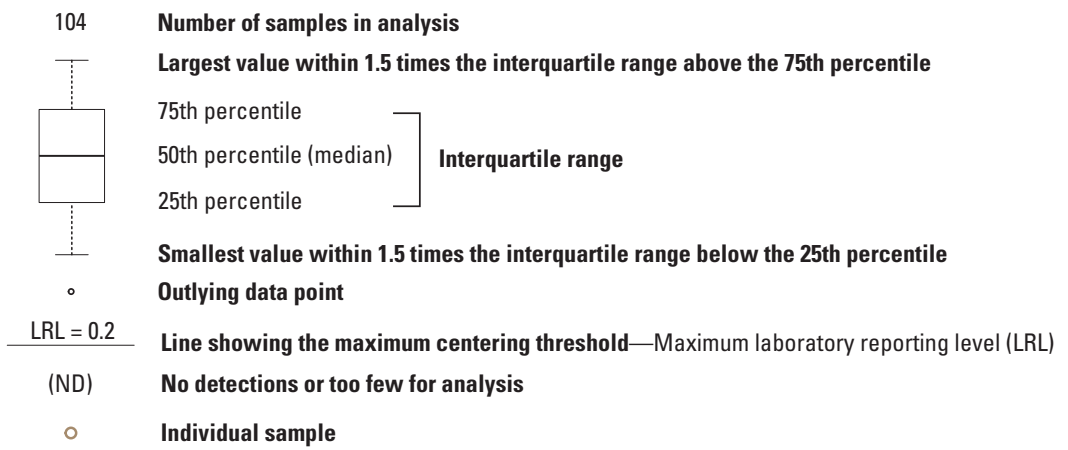

Figure 5. Boxplots showing volatile organic compound data by analyte for environmental and quality-control samples associated with passive samplers in sentinel wells, Kirtland Air Force Base, Albuquerque, New Mexico, November 2018-April 2019.

Quality-control samples include field, equipment, and source blanks, where the maximum laboratory reporting limit and the 25th, 50th, and 75th percentiles have been estimated by using the robust regression order statistic method (Helsel, 2012). 
Replicate variability was analyzed by evaluating replicate pairs for each sampling method (table 3). Sequential replicate pairs were collected during quarterly sampling for the pump method from 2013 to 2017, and split-replicate pairs were collected for the passive method from 2017 to 2019. Replicate variability, for each sampling method, was estimated by using average standard deviation (Mueller and others, 2015), which is a conservative estimate of variability and decreases the likelihood of passive and pump method concentrations agreeing for higher concentration analytes within statistical measures. For each sampling method, the standard deviation for each replicate pair was calculated for each analyte, and then the average of the standard deviations for each analyte was determined. The 90-percent confidence intervals about a single sample are presented in table 3 ; there is 90 -percent confidence that the true value of any individual measurement for an analyte will lie within the range given in table 3.

\section{Volatile Organic Compounds}

The number of source solution, equipment, and field organic blanks associated with passive sampling with only VOC detections are reported by analyte in table 4. (Collection methods and sample purpose are described in the "Methods" section under "Quality Assurance and Quality Control.") Because of the frequency of low-level VOC concentrations, the scope of this analysis was expanded to apply to all environmental samples collected for this study, as well as all environmental and quality-control samples collected during the period from November 2018 through July 2019 at the other sentinel wells (Bell and others, 2018). These dates encompass the time in November 2018 when analysis of VOCs was switched from the USGS contract laboratory to the NWQL, and the method detection limits, which vary with each compound, decreased an order of magnitude or more for most of the compounds in NWQL method O-4127-96 (Connor and others, 1998) compared to the previous EPA Method $8260 \mathrm{C}$ (EPA, 2006). It should be noted that the NWQL has a reporting level method (RLDQC), which is a reporting level

Table 2. Analysis results for source, equipment, and field inorganic blanks with major ion or trace element detections above the detection limit for sentinel wells at and near Kirtland Air Force Base, Albuquerque, New Mexico.

[--, no value; <, less than; mg/L, milligrams per liter; $\mu \mathrm{g} / \mathrm{L}$, micrograms per liter]

\begin{tabular}{|c|c|c|c|c|c|c|}
\hline Analyte & $\begin{array}{l}\text { Number of } \\
\text { blanks }\end{array}$ & $\begin{array}{l}\text { Number of blanks with } \\
\text { a value greater than the } \\
\text { laboratory detection level }\end{array}$ & $\begin{array}{l}\text { Concentration } \\
\text { range of blank } \\
\text { detections }\end{array}$ & $\begin{array}{l}\text { Concentration } \\
\text { for threshold } \\
\text { of influence }\end{array}$ & Unit & $\begin{array}{c}\text { Percentage of } \\
\text { environmental } \\
\text { samples below } \\
\text { threshold }\end{array}$ \\
\hline \multicolumn{7}{|c|}{ Source blanks_-Pumps and passive samplers } \\
\hline No detections & 3 & 0 & -- & -- & -- & -- \\
\hline \multicolumn{7}{|c|}{ Equipment blanks_-Pumps } \\
\hline Lead & 4 & 1 & $<0.02-0.152$ & 1.52 & $\mu \mathrm{g} / \mathrm{L}$ & -- \\
\hline \multicolumn{7}{|c|}{ Field blanks_-Pumps } \\
\hline Calcium & 1 & 1 & 0.026 & 0.26 & $\mathrm{mg} / \mathrm{L}$ & -- \\
\hline Cobalt & 1 & 1 & 0.063 & 0.63 & $\mu \mathrm{g} / \mathrm{L}$ & -- \\
\hline Copper & 1 & 1 & 0.83 & 8.3 & $\mu \mathrm{g} / \mathrm{L}$ & -- \\
\hline Calcium & 3 & 1 & $<0.022-0.041$ & 0.41 & $\mathrm{mg} / \mathrm{L}$ & -- \\
\hline Chloride & 3 & 1 & $<0.02-0.06$ & 0.6 & $\mathrm{mg} / \mathrm{L}$ & -- \\
\hline Barium & 3 & 1 & $<0.1-0.17$ & 1.7 & $\mu \mathrm{g} / \mathrm{L}$ & -- \\
\hline Copper & 3 & 1 & $<0.2-1.6$ & 16 & $\mu \mathrm{g} / \mathrm{L}$ & 36 \\
\hline \multicolumn{7}{|c|}{ Field blanks_-Passive samplers } \\
\hline Calcium & 1 & 1 & 0.022 & 0.22 & $\mathrm{mg} / \mathrm{L}$ & -- \\
\hline Chloride & 1 & 1 & 0.03 & 0.3 & $\mathrm{mg} / \mathrm{L}$ & -- \\
\hline Barium & 1 & 1 & 0.4 & 4 & $\mu \mathrm{g} / \mathrm{L}$ & -- \\
\hline
\end{tabular}

${ }^{1}$ Collected over duration of use from October 2017 through February 2019. 
by DQCALC software (Standard Practice D7510-10; ASTM International, 2010) that can report up to 10 percent below the method detection limit (USGS, 2015).

Environmental and blank data were analyzed with the NADA software package (Lee, 2015). If the ratio of number of censored values to the total number of samples was greater than 80 percent, statistical analysis could not be performed. If compounds met the required conditions, boxplots were created for the compounds and sample types (fig. 5). If no data represented the blanks, the analysis was not performed for those blanks. For example, the analysis for the benzene equipment and source blanks could not be performed, so no data are presented in the boxplot (fig. 5). Some compounds had detections above the LRL in the source blank. These source blank detections are from a blank performed on IBW, rather than the typical organic blank water (OBW), which is used for organic blanks. During the vertically profiled study, the samplers were filled with IBW rather than OBW, which was necessary because all analytes had to be sampled from the same passive sampler. OBW can contain low levels of trace elements because of the recycled glass containers used by the manufacturer to store the water, and it is not recommended for use when analyzing for trace elements. OBW source blanks had no detections of VOCs, but the IBW source blank did have low levels of some VOC compounds, such as xylenes. Field and equipment blanks for toluene were higher than the LRL, possibly because of unavoidable atmospheric contamination due to the construction of the passive sampler and the nature of some of the site locations. For instance, road and sidewalk construction was ongoing at the Trumbull sites from November 2018 through April 2019.

Based on guidance from the EPA (1989, pages 5-16 and 5-17) and Mueller and others (2015), VOCs detected in environmental samples were censored at raised reporting levels, referred to as the "concentration for threshold of influence" in table 4 . The raised reporting levels were set equal to five times the maximum concentration detected in any blank and were applied to results in all environmental VOC samples (EPA, 1989). For a few common laboratory contaminants (acetone, dichloromethane, methyl ethyl ketone, and toluene), the reporting level was raised to 10 times the maximum concentration detected in the blank (EPA, 1989, pages 5-16 and 5-17). All VOCs detected in environmental samples were below the raised reporting levels except acetone and carbon disulfide; therefore, the analysis of VOCs is not included in this study.

\section{Comparison of Results from Passive and Pumped Sampling Methods}

The comparison of results from the pump and passive sampling methods includes 1:1 correspondence plots, the analysis of the RPD between paired pump and passive results, and the evaluation of results with the method variability.

Correspondence between results from the pump and passive methods for major ions in CC-1A and SO-1A can be seen in the $1: 1$ correspondence plots (fig. 6). The major ion concentrations are very close to the 1:1 line, with slight variation in sulfate for the TR-1A and VA-1 results.

Trace element concentrations (fig. 7) exhibited less correspondence between the two sampling methods than the major ion concentrations. The correspondence was strongest for CC-1A and SO-1A. Analytes that had no concentrations on or near the 1:1 line for CC-1A included antimony, manganese, nickel, and zinc. SO-1 A had at least one result pair crossing or near the 1:1 line for all analytes, but antimony, cobalt, iron, nickel, and zinc had values far above and (or) below the 1:1 line. TR-1A and VA-1A had the most analyte concentrations that did not correspond to the 1:1 line. Arsenic, nickel, molybdenum, selenium, uranium, and vanadium results were outside of the 1:1 line for both sites. Additional trace elements not on the 1:1 line for TR-1A were cadmium, chromium, iron, manganese, and zinc. VA-1A only had one other result that did not correspond with the 1:1 line, and that was for arsenic.

\section{Relative Percent Difference Between Sampling Methods}

RPD was calculated for 34 analytes for each passive sample as compared to the same analytes from the pump sample collected the following day (tables 5, 6, 7, and 8). The results were evaluated for the number of analytes within set criteria. 
Table 3. Results of inorganic replicate variability analysis for pump and passive sampling methods at sentinel wells at and near Kirtland Air Force Base, Albuquerque, New Mexico.

$\left[ \pm\right.$, plus or minus; $\mu \mathrm{g} / \mathrm{L}$, micrograms per liter; $\mathrm{mg} / \mathrm{L}$, milligrams per liter; NA, not available; $\delta^{18} \mathrm{O}$, stable isotope of oxygen; $\delta^{2} \mathrm{H}$, stable isotope of hydrogen. Beryllium, cadmium, and silver had two or fewer pairs, and the variability was not quantified for either method. Chromium, copper, lead, and thallium had two or fewer pairs, and the variability was not quantified for the passive method]

\begin{tabular}{|c|c|c|c|}
\hline Analyte & $\begin{array}{l}\text { Pump sampling method variability } \\
\text { (90-percent confidence) }\end{array}$ & $\begin{array}{l}\text { Passive sampling method variability } \\
\text { (90-percent confidence) }\end{array}$ & Unit \\
\hline Alkalinity & \pm 2.42 & \pm 1.45 & $\mathrm{mg} / \mathrm{L}$ \\
\hline Aluminum & \pm 0.61 & \pm 0.01 & $\mu \mathrm{g} / \mathrm{L}$ \\
\hline Antimony & \pm 0.03 & \pm 0.07 & $\mu \mathrm{g} / \mathrm{L}$ \\
\hline Arsenic & \pm 0.06 & \pm 0.07 & $\mu \mathrm{g} / \mathrm{L}$ \\
\hline Barium & \pm 3.35 & \pm 6.27 & $\mu \mathrm{g} / \mathrm{L}$ \\
\hline Bicarbonate & \pm 2.70 & \pm 1.69 & $\mathrm{mg} / \mathrm{L}$ \\
\hline Boron & \pm 1.21 & \pm 2.65 & $\mu \mathrm{g} / \mathrm{L}$ \\
\hline Bromide & \pm 0.01 & \pm 0.003 & $\mathrm{mg} / \mathrm{L}$ \\
\hline Calcium & \pm 0.99 & \pm 1.52 & $\mathrm{mg} / \mathrm{L}$ \\
\hline Chloride & \pm 0.14 & \pm 0.04 & $\mathrm{mg} / \mathrm{L}$ \\
\hline Chromium & \pm 0.06 & NA & $\mu \mathrm{g} / \mathrm{L}$ \\
\hline Cobalt & \pm 0.03 & \pm 0.16 & $\mu \mathrm{g} / \mathrm{L}$ \\
\hline Copper & \pm 0.08 & NA & $\mu \mathrm{g} / \mathrm{L}$ \\
\hline Fluoride & \pm 0.01 & \pm 0.01 & $\mathrm{mg} / \mathrm{L}$ \\
\hline Iron & \pm 1.37 & \pm 2.98 & $\mu \mathrm{g} / \mathrm{L}$ \\
\hline Lead & \pm 0.01 & NA & $\mu \mathrm{g} / \mathrm{L}$ \\
\hline Lithium & \pm 0.30 & \pm 0.61 & $\mu \mathrm{g} / \mathrm{L}$ \\
\hline Magnesium & \pm 0.11 & \pm 0.28 & $\mathrm{mg} / \mathrm{L}$ \\
\hline Manganese & \pm 0.92 & \pm 1.02 & $\mu \mathrm{g} / \mathrm{L}$ \\
\hline Molybdenum & \pm 0.18 & \pm 0.16 & $\mu \mathrm{g} / \mathrm{L}$ \\
\hline Nickel & \pm 0.10 & \pm 0.25 & $\mu \mathrm{g} / \mathrm{L}$ \\
\hline Potassium & \pm 0.06 & \pm 0.15 & $\mathrm{mg} / \mathrm{L}$ \\
\hline Selenium & \pm 0.02 & \pm 0.20 & $\mu \mathrm{g} / \mathrm{L}$ \\
\hline Silica $\left(\mathrm{SiO}_{2}\right)$ & \pm 0.43 & \pm 1.18 & $\mathrm{mg} / \mathrm{L}$ \\
\hline Sodium & \pm 0.95 & \pm 0.79 & $\mathrm{mg} / \mathrm{L}$ \\
\hline Strontium & \pm 4.9 & \pm 19.32 & $\mu \mathrm{g} / \mathrm{L}$ \\
\hline Sulfate & \pm 0.22 & \pm 0.48 & $\mathrm{mg} / \mathrm{L}$ \\
\hline Thallium & \pm 0.002 & NA & $\mu \mathrm{g} / \mathrm{L}$ \\
\hline Uranium & \pm 0.06 & \pm 0.12 & $\mu \mathrm{g} / \mathrm{L}$ \\
\hline Vanadium & \pm 0.11 & \pm 0.10 & $\mu \mathrm{g} / \mathrm{L}$ \\
\hline Zinc & \pm 0.90 & \pm 1.19 & $\mu \mathrm{g} / \mathrm{L}$ \\
\hline$\delta^{18} \mathrm{O}$ & \pm 0.03 & \pm 0.06 & per mil \\
\hline$\delta^{2} \mathrm{H}$ & \pm 1.40 & \pm 0.41 & per mil \\
\hline
\end{tabular}


Table 4. Volatile organic compounds detected in environmental and quality-control samples collected from passive samplers in sentinel wells at and near Kirtland Air Force Base, Albuquerque, New Mexico, November 2018 to April 2019.

$[\mu \mathrm{g} / \mathrm{L} ;$ micrograms per liter; 一, does not apply]

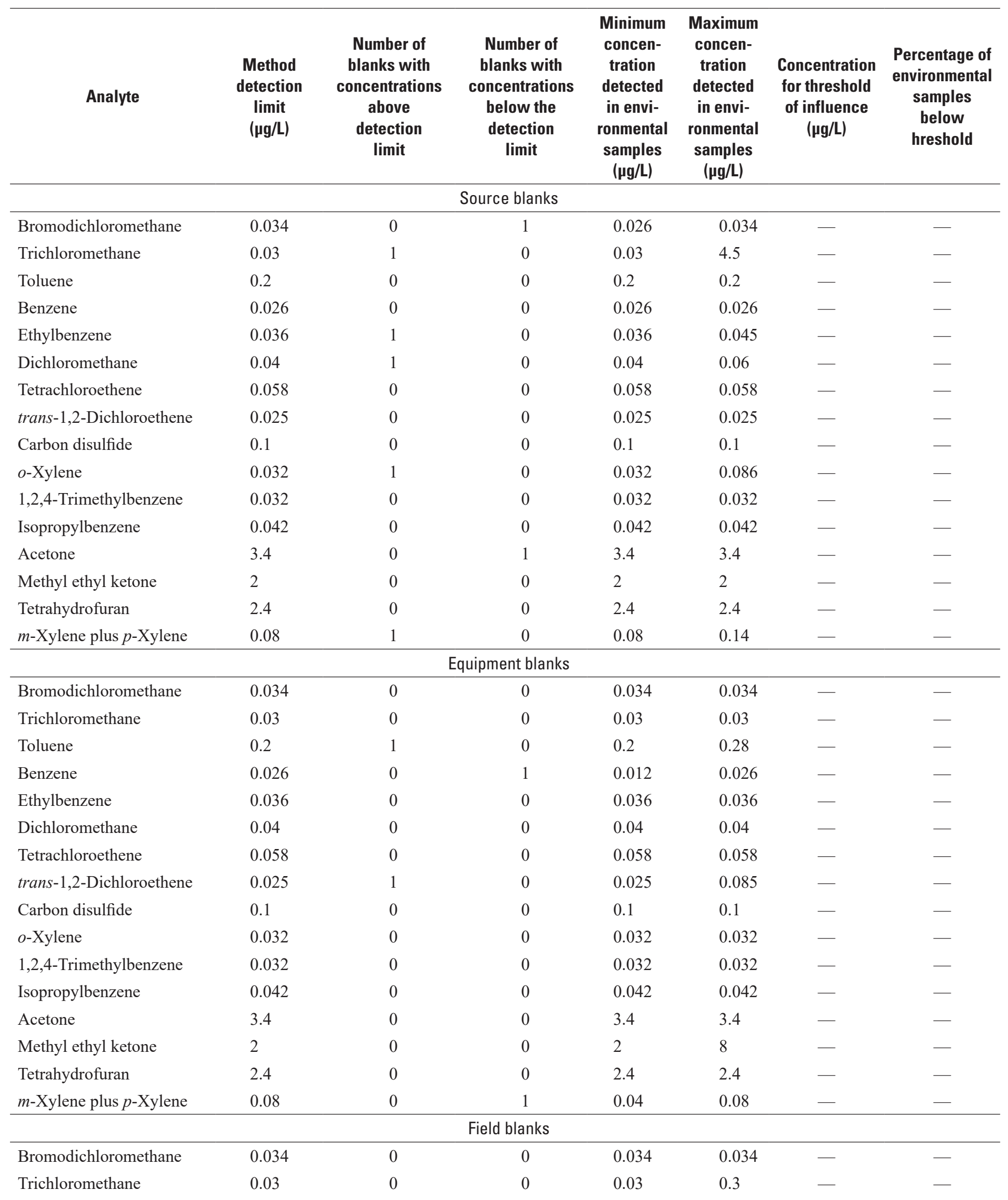


Table 4. Volatile organic compounds detected in environmental and quality-control samples collected from passive samplers in sentinel wells at and near Kirtland Air Force Base, Albuquerque, New Mexico, November 2018 to April 2019. - Continued

$[\mu \mathrm{g} / \mathrm{L} ;$ micrograms per liter; —, does not apply]

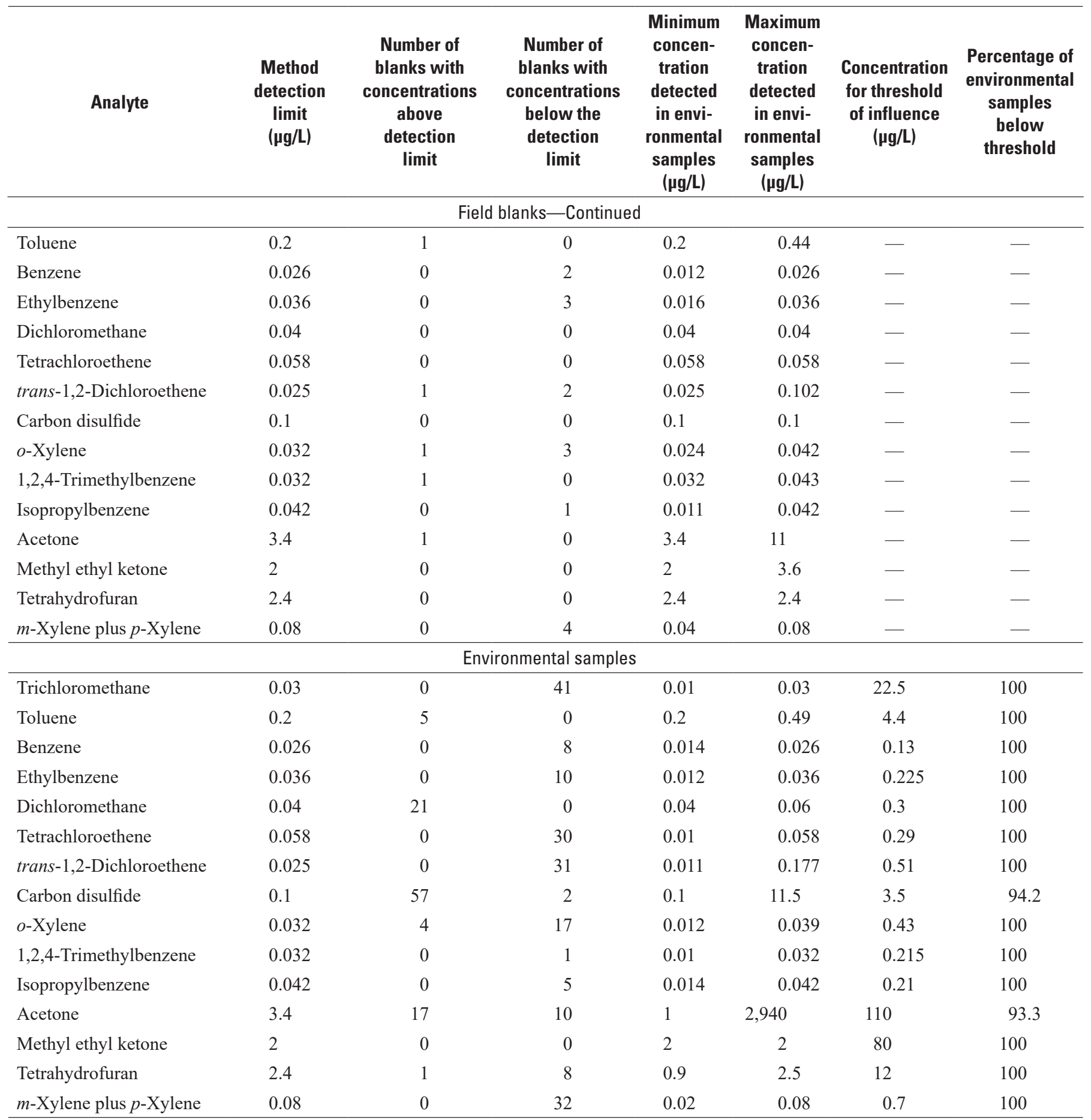



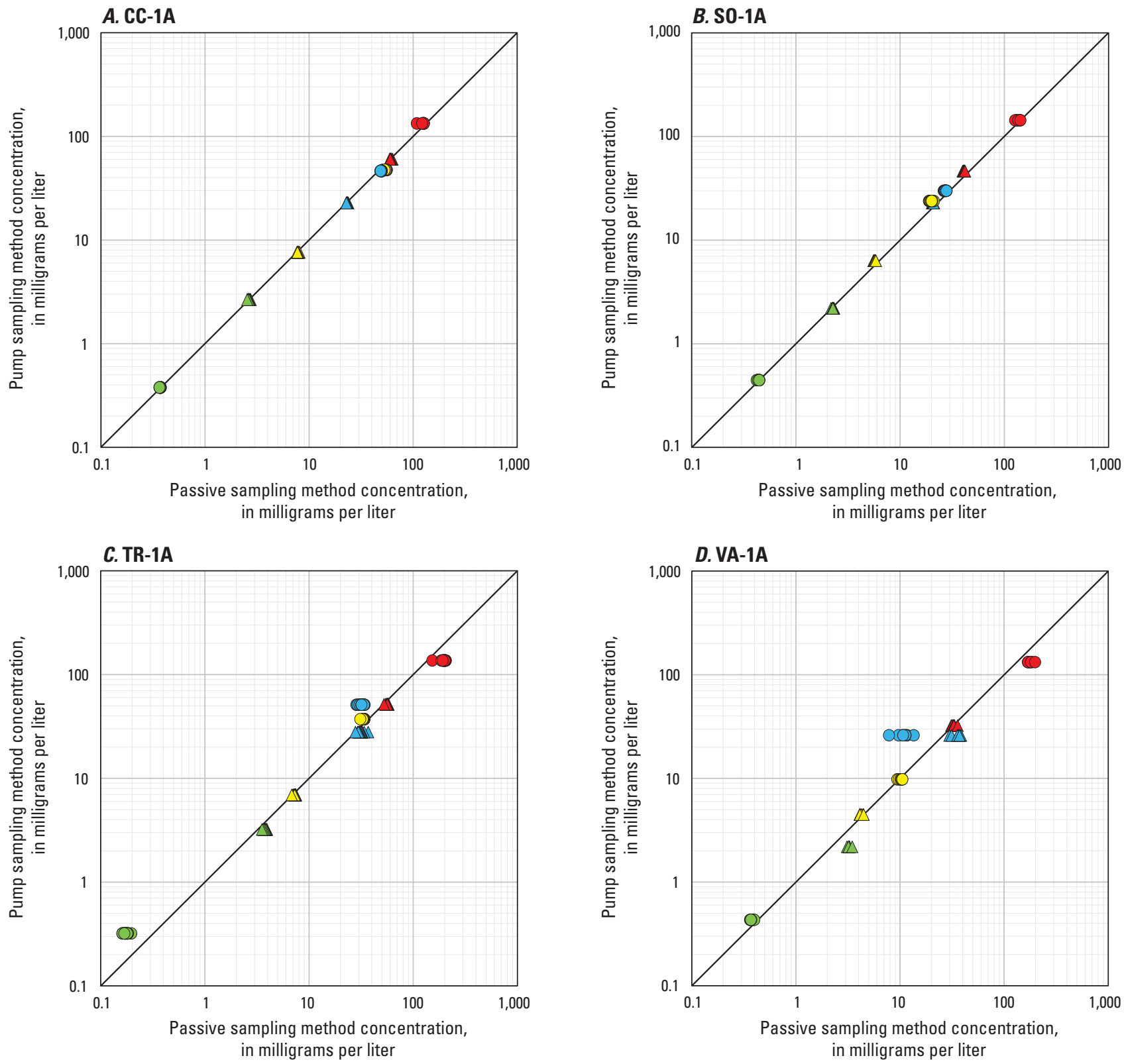

EXPLANATION

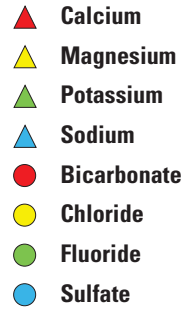

Figure 6. Passive sampling method concentrations versus pump sampling method concentrations for major ions for sentinel wells $A$, CC-1A, B, S0-1A, C, TR-1A, and D, VA-1A, at and near Kirtland Air Force Base, Albuquerque, New Mexico. Solid black line indicates one-to-one (1:1) correspondence. 


\section{A. CC-1A}

Passive sampling method concentration, in milligrams per liter $(\mathrm{mg} / \mathrm{L})$

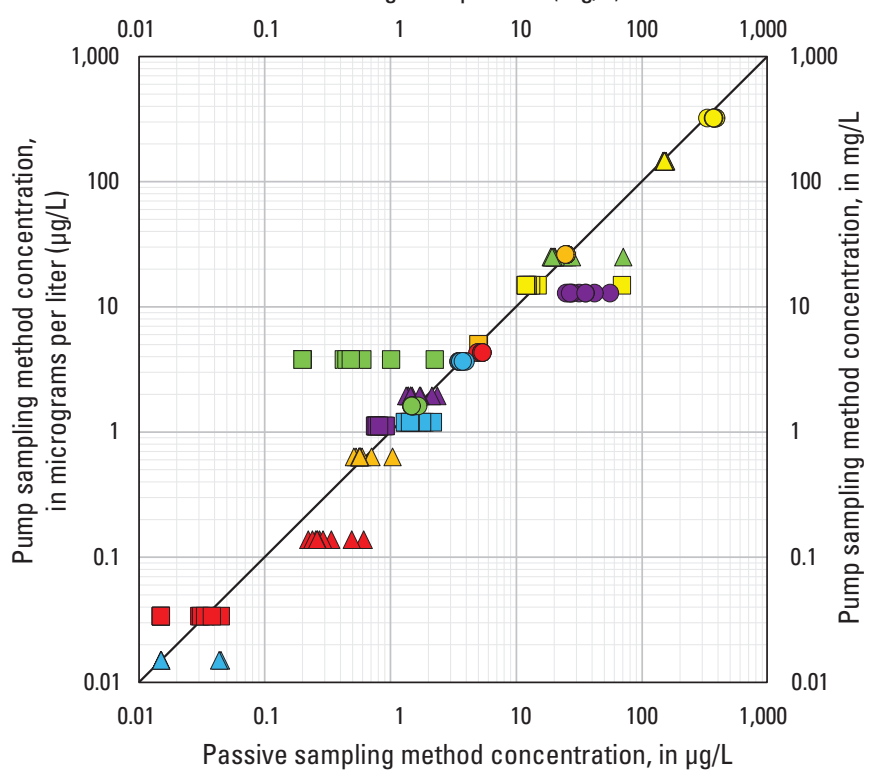

\section{TR-1A}

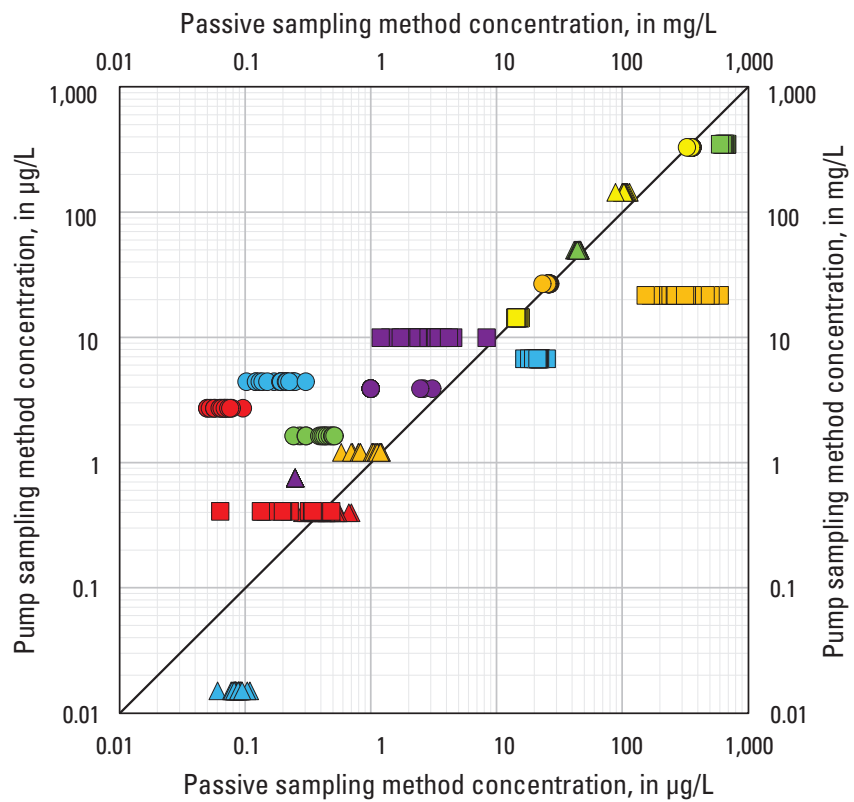

\section{B. SO-1A}

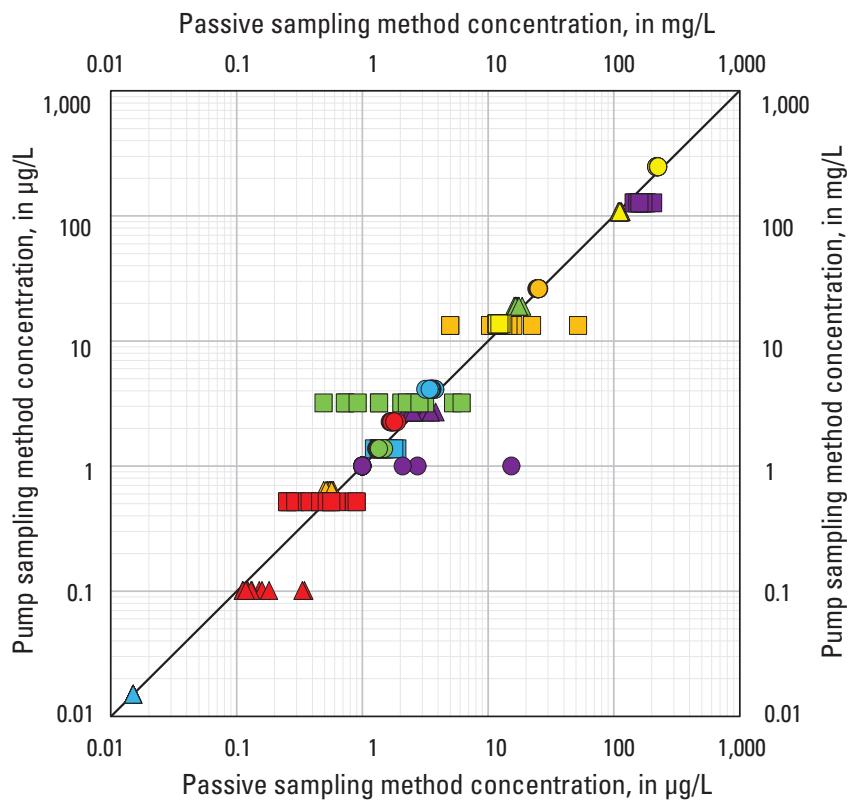

D. VA-1A

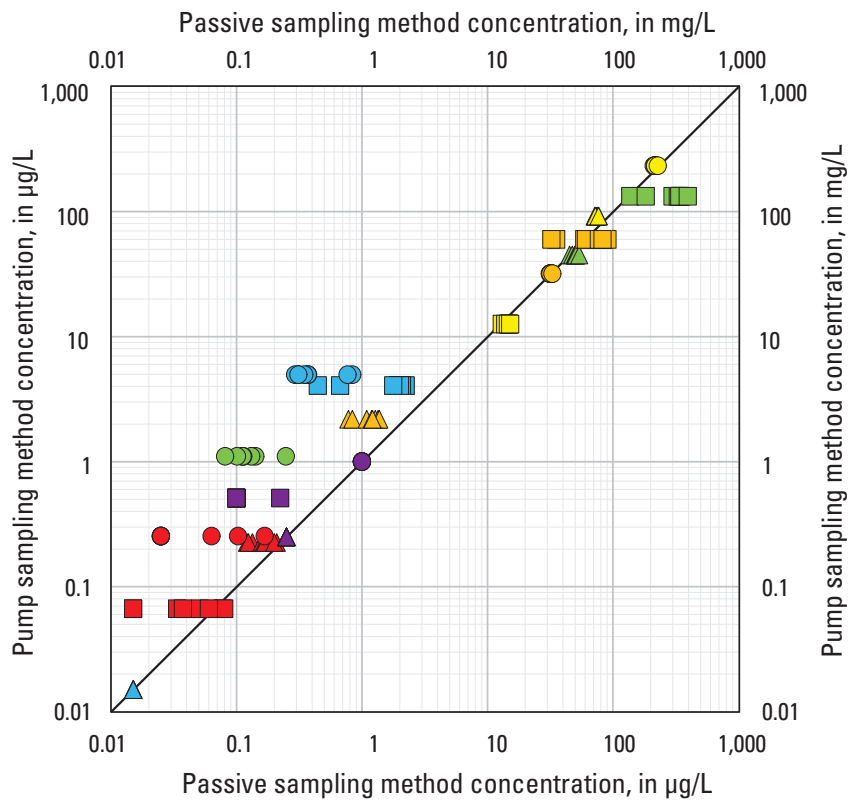

\section{EXPLANATION}
$\Delta$ Antimony, in $\mu \mathrm{g} / \mathrm{L}$
$\square$ Cobalt, in $\mu \mathrm{g} / \mathrm{L}$
Selenium, in $\mu \mathrm{g} / \mathrm{L}$
$\triangle$ Arsenic, in $\mu \mathrm{g} / \mathrm{L}$
$\square$ Iron, in $\mu \mathrm{g} / \mathrm{L}$
$\triangle$ Barium, in $\mu \mathrm{g} / \mathrm{L}$
$\square$ Lithium, in $\mu \mathrm{g} / \mathrm{L}$
Silica, in $\mathrm{mg} / \mathrm{L}$ as silicon dioxide
$\triangle$ Boron, in $\mu \mathrm{g} / \mathrm{L}$
$\square$ Manganese, in $\mu \mathrm{g} / \mathrm{L}$
Strontium, in $\mu \mathrm{g} / \mathrm{L}$
$\triangle$ Cadmium, in $\mu \mathrm{g} / \mathrm{L}$
$\square$ Molybdenum, in $\mu \mathrm{g} / \mathrm{L}$
Uranium, in $\mu \mathrm{g} / \mathrm{L}$
$\Delta$ Chromium, in $\mu \mathrm{g} / \mathrm{L}$
Nickel, in $\mu \mathrm{g} / \mathrm{L}$
Vanadium, in $\mu \mathrm{g} / \mathrm{L}$
Zinc, in $\mu \mathrm{g} / \mathrm{L}$

Figure 7. Passive sampling method concentrations versus pump sampling method concentrations for trace elements for sentinel wells A, CC-1A, B, S0-1A, C, TR-1A, and D, VA-1A, at and near Kirtland Air Force Base, Albuquerque, New Mexico. Solid black line indicates one-to-one (1:1) correspondence. 
Table 5. Relative percent difference (RPD) between pump and passive sampling results at sentinel well CC-1A near Kirtland Air Force Base, Albuquerque, New Mexico.

$\left[\%\right.$, percent; \pm , plus or minus; ND, passive or pump result was not detected, and RPD could not be calculated; NA, data were not available; --, not calculated; $\delta^{18} \mathrm{O}$, stable isotope of oxygen; $\delta^{2} \mathrm{H}$, stable isotope of hydrogen. Samplers are listed shallow (Sampler 1) to deep (Sampler 10). Dark green shaded areas indicate that results were within the RPD criteria (Imbrigiotta and Harte, 2020). Gray shaded areas indicate the minimum RPD, for each analyte, that met the RPD criteria. Yellow shaded areas are results that did not meet the RPD criteria but were within the estimated sampling variability]

\begin{tabular}{|c|c|c|c|c|c|c|c|c|c|c|c|c|}
\hline \multirow[b]{2}{*}{ Analyte } & \multicolumn{11}{|c|}{ Relative percent difference (\%) } & \multirow{2}{*}{$\begin{array}{c}\text { RPD } \\
\text { criteria } \\
(\%)\end{array}$} \\
\hline & Sampler 1 & Sampler 2 & Sampler 3 & Sampler 4 & Sampler 5 & Sampler 6 & Sampler 7 & Sampler 8 & Sampler 9 & Sampler 10 & $\begin{array}{l}\text { Sampler } \\
\text { average }\end{array}$ & \\
\hline $\mathrm{pH}$ & a -9.8 & b0.5 & a5.0 & $\mathrm{a} 4.0$ & a5.9 & a2.3 & a -4.5 & $\mathrm{a}-1.0$ & ${ }^{\mathrm{a}} 0.6$ & 2.3 & ${ }^{\mathrm{a}} 0.6$ & \pm 15 \\
\hline Specific conductance & a4.3 & a2.9 & ${ }^{\mathrm{a}} 6.1$ & ${ }^{\mathrm{a}} 6.5$ & b1.4 & a5.5 & a2.8 & a 4.8 & a 4.7 & $\mathrm{a} 4.6$ & $\mathrm{a} 4.4$ & \pm 15 \\
\hline Alkalinity & $\mathrm{b}-4.9$ & $\mathrm{a}-6.9$ & $\mathrm{a}-5.9$ & a -7.8 & a -5.9 & $\mathrm{~b}-4.9$ & $\mathrm{a}-5.5$ & $\mathrm{~b}-4.9$ & -20.4 & a -8.8 & $\mathrm{a}-7.5$ & \pm 15 \\
\hline Aluminum & ND & ND & ND & ND & ND & ND & ND & ND & ND & ND & ND & -- \\
\hline Antimony & 126.2 & 112.2 & 84.0 & 65.6 & 71.0 & 59.1 & b46.5 & 62.2 & 53.7 & 61.4 & 80.5 & \pm 50 \\
\hline Arsenic & $\mathrm{a}-17.3$ & $\mathrm{a}-9.2$ & $\mathrm{~b}-6.4$ & $a-12.1$ & $\mathrm{a} 48.3$ & $\mathrm{a}-21.2$ & $\mathrm{a}-11.9$ & a 10.9 & a -9.7 & $a-10.9$ & $\mathrm{a}-1.7$ & \pm 50 \\
\hline Barium & ${ }^{\mathrm{a}} 6.1$ & a3.5 & ${ }^{\mathrm{b}} 0.3$ & ${ }^{\mathrm{a}} 6.0$ & a2.6 & a3.1 & a3.8 & ${ }^{\mathrm{a}} 0.7$ & a 2.3 & a2.9 & a3.1 & \pm 25 \\
\hline Bicarbonate & $\mathrm{b}-4.4$ & $\mathrm{a}-6.5$ & a -5.4 & $\mathrm{a}-7.6$ & $\mathrm{a}-5.6$ & $a-4.5$ & $\mathrm{a}-5.0$ & $\mathrm{~b}-4.4$ & -20.2 & $a-8.3$ & $\mathrm{a}-7.1$ & \pm 15 \\
\hline Boron & a -20.8 & $\mathrm{a}-21.7$ & b1.3 & $\mathrm{a}-4.9$ & 95.3 & -27.3 & $\mathrm{a}-23.6$ & ${ }^{\mathrm{a}} 10.0$ & -28.7 & -26.1 & a5.6 & \pm 25 \\
\hline Bromide & ${ }^{\mathrm{a}} 17.4$ & ${ }^{\mathrm{a}} 13.3$ & ${ }^{\mathrm{a}} 15.7$ & a 17.6 & ${ }^{\mathrm{a}} 14.8$ & a 14.8 & ${ }^{\mathrm{a}} 16.4$ & b 11.5 & a 13.4 & a 13.2 & a 14.8 & \pm 50 \\
\hline Calcium & a5.3 & a3.0 & a 2.2 & a2.4 & ${ }^{\mathrm{a}} 1.2$ & a0 0.6 & a 1.1 & $\mathrm{a}-1.1$ & ${ }^{\mathrm{a}} 0.8$ & ${ }^{\mathrm{b}} 0.3$ & a1.6 & \pm 15 \\
\hline Chloride & 17.1 & ${ }^{\mathrm{a}} 12.6$ & 15.5 & 16.1 & ${ }^{\mathrm{a}} 13.9$ & ${ }^{\mathrm{a}} 12.7$ & ${ }^{\mathrm{a}} 14.8$ & b8.0 & ${ }^{a} 12.2$ & a 11.9 & $\mathrm{a} 13.5$ & \pm 15 \\
\hline Chromium & $\mathrm{a}-34.3$ & a -33.5 & a 19.2 & b9.3 & $a-11.5$ & $a-37.5$ & $\mathrm{a}-26.9$ & $\mathrm{a}-13.3$ & $\mathrm{a}-29.4$ & $a-29.5$ & $a-17.0$ & \pm 50 \\
\hline Cobalt & ND & ND & ND & ND & $\mathrm{a}-10.3$ & $\mathrm{a}-7.4$ & ND & ${ }^{\mathrm{b}} 0.0$ & ND & a 12.3 & $\mathrm{a}-1.0$ & \pm 50 \\
\hline Copper & ND & ND & ND & ND & ND & ND & ND & ND & ND & ND & ND & -- \\
\hline Fluoride & $\mathrm{a}-0.3$ & $\mathrm{a}-0.8$ & b0.0 & a -0.5 & a -0.5 & a -3.0 & $\mathrm{a}-3.0$ & $\mathrm{a}-1.3$ & $\mathrm{a}-1.6$ & a -3.0 & $\mathrm{a}-1.4$ & \pm 15 \\
\hline Iron & ND & ND & ND & ND & ND & ND & ND & ND & ND & ND & ND & -- \\
\hline Lead & ND & ND & ND & ND & ND & ND & ND & ND & ND & ND & ND & -- \\
\hline Lithium & $\mathrm{a}-17.2$ & $\mathrm{a}-18.2$ & $\mathrm{~b}-0.4$ & $\mathrm{a}-12.1$ & 129.4 & $\mathrm{a}-22.4$ & $a-18.6$ & $\mathrm{a}-19.1$ & $\mathrm{a}-21.6$ & $\mathrm{a}-21.9$ & a20.5 & \pm 25 \\
\hline Magnesium & a6.5 & a3.2 & a3.7 & a4.0 & a2.9 & a2.4 & a3.0 & b0.7 & a2.4 & a1.9 & a3.1 & \pm 15 \\
\hline Manganese & -159.5 & -180.0 & -145.3 & -180.0 & -115.6 & -180.0 & -180.0 & -157.7 & -154.7 & $\mathrm{c}-51.0$ & -145.1 & \pm 50 \\
\hline Molybdenum & $\mathrm{a} 44.2$ & 58.4 & ${ }^{\mathrm{a}} 15.6$ & ${ }^{a} 22.7$ & a32.7 & a9.2 & b8.7 & a39.7 & ${ }^{\mathrm{a}} 19.4$ & ${ }^{\mathrm{a}} 18.1$ & a2 28.4 & \pm 50 \\
\hline Nickel & $\mathrm{a}-31.9$ & $\mathrm{a}-36.4$ & $a-38.5$ & $\mathrm{a}-37.1$ & a -34.8 & $a-37.7$ & $\mathrm{a}-35.3$ & $\mathrm{a}-22.8$ & b -19.4 & $\mathrm{a}-31.2$ & $\mathrm{a}-32.3$ & \pm 50 \\
\hline Potassium & a3.3 & ${ }^{\mathrm{a}} 1.5$ & ${ }^{\mathrm{a}} 1.6$ & $\mathrm{a}-1.3$ & ${ }^{\mathrm{b}} 0.4$ & $\mathrm{a}-2.7$ & $\mathrm{a}-1.6$ & $\mathrm{a}-2.2$ & $\mathrm{a}-0.8$ & $\mathrm{a}-4.3$ & $\mathrm{a}-0.6$ & \pm 15 \\
\hline Selenium & a22.0 & a 18.2 & a13.9 & a21.9 & b13.3 & a21.8 & a22.5 & a 19.9 & a20.3 & a22.5 & a 19.7 & \pm 50 \\
\hline Silica & $\mathrm{a}-4.4$ & $\mathrm{a}-4.1$ & $\mathrm{a}-4.4$ & $\mathrm{~b}-3.5$ & a -3.9 & $\mathrm{a}-4.1$ & $\mathrm{a}-4.5$ & a -4.7 & $\mathrm{a}-3.6$ & $\mathrm{a}-5.8$ & $\mathrm{a}-4.3$ & \pm 25 \\
\hline Sodium & a 4.8 & a3.0 & a2.6 & a2.8 & a 1.7 & a1.6 & a1.9 & b 0.0 & a1.6 & ${ }^{\mathrm{a}} 0.4$ & a2.1 & \pm 15 \\
\hline Strontium & ${ }^{\mathrm{a}} 18.3$ & a 14.9 & b2.7 & $\mathrm{a} 17.5$ & a 18.8 & $\mathrm{a} 15.3$ & $\mathrm{a} 15.2$ & ${ }^{\mathrm{a}} 13.0$ & ${ }^{\mathrm{a}} 13.2$ & ${ }^{\mathrm{a}} 14.2$ & a 14.4 & \pm 25 \\
\hline Sulfate & a8 8.1 & a5.4 & a 7.6 & a8 8.0 & a 7.2 & ${ }^{\mathrm{a}} 6.7$ & a 7.8 & b4.7 & ${ }^{\mathrm{a}} 6.4$ & a5.3 & ${ }^{\mathrm{a}} 6.7$ & \pm 15 \\
\hline
\end{tabular}


Table 5. Relative percent difference (RPD) between pump and passive sampling results at sentinel well CC-1A near Kirtland Air Force Base, Albuquerque, New Mexico.Continued

$\left[\%\right.$, percent; \pm , plus or minus; ND, passive or pump result was not detected, and RPD could not be calculated; NA, data were not available; --, not calculated; $\delta^{18} \mathrm{O}$, stable isotope of oxygen; $\delta^{2} \mathrm{H}$, stable isotope of hydrogen. Samplers are listed shallow (Sampler 1) to deep (Sampler 10). Dark green shaded areas indicate that results were within the RPD criteria (Imbrigiotta and Harte, 2020). Gray shaded areas indicate the minimum RPD, for each analyte, that met the RPD criteria. Yellow shaded areas are results that did not meet the RPD criteria but were within the estimated sampling variability]

\begin{tabular}{|c|c|c|c|c|c|c|c|c|c|c|c|c|}
\hline \multirow[b]{2}{*}{ Analyte } & \multicolumn{11}{|c|}{ Relative percent difference (\%) } & \multirow{2}{*}{$\begin{array}{c}\text { RPD } \\
\text { criteria } \\
(\%)\end{array}$} \\
\hline & Sampler 1 & Sampler 2 & Sampler 3 & Sampler 4 & Sampler 5 & Sampler 6 & Sampler 7 & Sampler 8 & Sampler 9 & Sampler 10 & $\begin{array}{l}\text { Sampler } \\
\text { average }\end{array}$ & \\
\hline Uranium & $\mathrm{b}-2.6$ & $\mathrm{a}-5.4$ & $\mathrm{a}-9.7$ & $\mathrm{a}-6.1$ & $\mathrm{a}-5.1$ & $\mathrm{a}-8.1$ & $\mathrm{a}-8.5$ & a3.3 & $\mathrm{a}-9.4$ & $\mathrm{a}-8.7$ & $a-6.0$ & \pm 50 \\
\hline Vanadium & $\mathrm{a}-5.3$ & a -4.3 & ${ }^{\mathrm{a}} 1.6$ & ${ }^{\mathrm{a}} 0.6$ & a8.1 & $\mathrm{a}-1.6$ & ${ }^{\mathrm{b}} 0.2$ & a 1.7 & a -2.1 & a2.7 & ${ }^{\mathrm{a}} 0.2$ & \pm 50 \\
\hline Zinc & 125.0 & 106.2 & 94.3 & 84.5 & 72.1 & 67.8 & 63.9 & 74.2 & 70.3 & 93.9 & 88.8 & \pm 25 \\
\hline$\delta^{18} \mathrm{O}$ & $\mathrm{a}-1.1$ & $\mathrm{a}-1.3$ & $\mathrm{a}-1.2$ & $\mathrm{a}-2.0$ & NA & $\mathrm{a}-1.3$ & $\mathrm{a}-1.5$ & $\mathrm{a}-2.2$ & $\mathrm{~b}-0.8$ & $a-3.4$ & $a-1.6$ & \pm 15 \\
\hline$\delta^{2} \mathrm{H}$ & b 0.3 & ${ }^{\mathrm{a}} 0.6$ & ${ }^{\mathrm{a}} 1.0$ & ${ }^{\mathrm{a}} 0.6$ & NA & a0.6 & $\mathrm{a}-1.7$ & $\mathrm{a}-1.9$ & $\mathrm{a}-0.9$ & $\mathrm{a}-3.5$ & $\mathrm{a}-0.5$ & \pm 15 \\
\hline
\end{tabular}

aResult is within the RPD criteria.

bMinimum RPD that met the RPD criteria.

${ }^{c}$ Result did not meet RPD criteria but was within the estimated sampling variability. 
Table 6. Relative percent difference (RPD) between pump and passive sampling results at sentinel well S0-1A near Kirtland Air Force Base, Albuquerque, New Mexico.

$\left[\%\right.$, percent; \pm , plus or minus; ND, passive or pump result was not detected and RPD could not be calculated; --, not calculated; $\delta^{18} \mathrm{O}$, stable isotope of oxygen; $\delta^{2} \mathrm{H}$, stable isotope of hydrogen. Samplers are listed shallow (Sampler 1) to deep (Sampler 13). Dark green shaded areas show results that were within the RPD criteria (Imbrigiotta and Harte, 2020) in last column. Gray shaded areas show the minimum RPD, for each analyte, that met the criteria in last column. Yellow shaded areas are results that did not meet the RPD criteria but were within the estimated sampling variability]

\begin{tabular}{|c|c|c|c|c|c|c|c|c|c|c|c|c|c|c|c|}
\hline \multirow[b]{2}{*}{ Analyte } & \multirow[b]{2}{*}{$\begin{array}{c}\text { Sampler } \\
1\end{array}$} & \multirow[b]{2}{*}{$\begin{array}{c}\text { Sampler } \\
2\end{array}$} & \multicolumn{12}{|c|}{ Relative percent difference (\%) } & \multirow{2}{*}{$\begin{array}{c}\text { RPD } \\
\text { criteria } \\
(\%)\end{array}$} \\
\hline & & & $\begin{array}{c}\text { Sampler } \\
\mathbf{3}\end{array}$ & $\begin{array}{c}\text { Sampler } \\
4\end{array}$ & $\begin{array}{c}\text { Sampler } \\
5\end{array}$ & $\begin{array}{c}\text { Sampler } \\
6\end{array}$ & $\begin{array}{c}\text { Sampler } \\
7\end{array}$ & $\begin{array}{c}\text { Sampler } \\
8\end{array}$ & $\begin{array}{c}\text { Sampler } \\
9\end{array}$ & $\begin{array}{c}\text { Sampler } \\
10\end{array}$ & $\begin{array}{c}\text { Sampler } \\
11\end{array}$ & $\begin{array}{c}\text { Sampler } \\
12\end{array}$ & $\begin{array}{c}\text { Sampler } \\
13\end{array}$ & $\begin{array}{l}\text { Sampler } \\
\text { average }\end{array}$ & \\
\hline $\mathrm{pH}$ & ${ }^{\mathrm{a}} 0.4$ & b1.9 & b1.9 & b2.4 & b4.3 & ${ }^{\mathrm{b}} 2.8$ & b2.7 & $\mathrm{b}_{2} .3$ & b1.5 & ${ }^{\mathrm{b}} 0.6$ & b0.9 & ${ }^{\mathrm{b}} 2.2$ & ${ }^{\mathrm{b}} 0.9$ & ${ }^{\mathrm{b}} 1.9$ & \pm 15 \\
\hline $\begin{array}{l}\text { Specific conduc- } \\
\text { tance }\end{array}$ & $\mathrm{b}-8.1$ & $\mathrm{~b}-8.2$ & $\mathrm{~b}-12.2$ & $\mathrm{~b}-10.4$ & -19.9 & $\mathrm{~b}-9.6$ & $\mathrm{~b}-8.9$ & $\mathrm{a}-7.5$ & $\mathrm{~b}-8.6$ & $\mathrm{~b}-10.0$ & $\mathrm{~b}-8.4$ & $\mathrm{~b}-9.0$ & $b-8.3$ & $\mathrm{~b}-9.9$ & \pm 15 \\
\hline Alkalinity & $\mathrm{b}-0.9$ & $\mathrm{~b}-1.8$ & $\mathrm{~b}-8.9$ & $\mathrm{~b}-4.4$ & $\mathrm{~b}-5.3$ & $\mathrm{~b}-0.9$ & $\mathrm{~b}-7.1$ & $\mathrm{~b}-1.8$ & $\mathrm{~b}-0.9$ & $\mathrm{~b}-3.4$ & b -11.9 & $\mathrm{~b}-4.4$ & ${ }^{\mathrm{a}} 0.0$ & $\mathrm{~b}-3.9$ & \pm 15 \\
\hline Aluminum & ND & ND & ND & ND & ND & ND & ND & ND & ND & ND & ND & ND & $\mathrm{ND}$ & ND & -- \\
\hline Antimony & b109.6 & b39.6 & b26.7 & a9.6 & b15.2 & b 10.3 & b18.6 & b44.4 & b18.6 & 56.7 & b24.8 & 106.7 & b15.7 & $\mathrm{b} 47.6$ & \pm 50 \\
\hline Arsenic & $\mathrm{b}-17.9$ & $\mathrm{a}-8.2$ & $\mathrm{~b}-19.6$ & $\mathrm{~b}-10.5$ & $\mathrm{~b}-13.7$ & $\mathrm{~b}-14.0$ & $\mathrm{~b}-11.6$ & $\mathrm{~b}-14.4$ & $\mathrm{~b}-12.6$ & $\mathrm{~b}-25.9$ & $\mathrm{~b}-14.9$ & $\mathrm{~b}-21.8$ & $\mathrm{~b}-11.4$ & $\mathrm{~b}-15.0$ & \pm 50 \\
\hline Barium & ${ }^{\mathrm{b}} 6.0$ & b6.4 & b1.9 & b2.7 & b1.9 & b4.3 & b 3.1 & b3.6 & b2.6 & b2.9 & ${ }^{\mathrm{a}} 0.1$ & ${ }^{\mathrm{b}} 1.0$ & b3.5 & b3.1 & \pm 25 \\
\hline Bicarbonate & $\mathrm{b}-1.3$ & $\mathrm{~b}-2.5$ & $\mathrm{~b}-9.1$ & $\mathrm{~b}-4.6$ & $\mathrm{~b}-5.9$ & $\mathrm{~b}-1.2$ & $\mathrm{~b}-7.3$ & $\mathrm{~b}-2.3$ & $\mathrm{~b}-1.2$ & $\mathrm{~b}-3.4$ & $\mathrm{~b}-12.1$ & $\mathrm{~b}-4.9$ & $\mathrm{a}-0.1$ & b -4.2 & \pm 15 \\
\hline Boron & $\mathrm{b}-9.9$ & $\mathrm{~b}-8.9$ & $\mathrm{~b}-14.3$ & $\mathrm{~b}-13.5$ & $\mathrm{~b}-8.2$ & $\mathrm{~b}-11.6$ & $\mathrm{~b}-13.8$ & $\mathrm{~b}-11.8$ & $b-16.5$ & $\mathrm{~b}-13.2$ & $\mathrm{a}-1.6$ & $b-13.6$ & $b-7.5$ & $\mathrm{~b}-11.0$ & \pm 25 \\
\hline Bromide & $\mathrm{b}-20.2$ & $b-19.6$ & b -21.3 & $b-19.8$ & $\mathrm{~b}-21.3$ & $b-16.0$ & $\mathrm{~b}-18.8$ & $\mathrm{a}-8.8$ & $b-15.2$ & b -19.6 & $\mathrm{~b}-11.3$ & $b-14.6$ & b -14.6 & $b-16.9$ & \pm 50 \\
\hline Calcium & $\mathrm{b}-10.7$ & $\mathrm{~b}-10.2$ & -15.1 & $\mathrm{~b}-13.4$ & $\mathrm{~b}-12.8$ & $\mathrm{~b}-11.2$ & $\mathrm{~b}-13.7$ & $\mathrm{~b}-11.0$ & $\mathrm{~b}-12.2$ & $\mathrm{~b}-13.3$ & $\mathrm{~b}-12.1$ & $\mathrm{~b}-10.6$ & a -9.9 & $\mathrm{~b}-12.0$ & \pm 15 \\
\hline Chloride & -18.9 & -19.9 & -22.7 & -21.6 & -20.1 & -17.7 & -20.4 & -18.0 & -17.2 & -18.6 & $\mathrm{a}-11.7$ & $\mathrm{~b}-14.7$ & -16.6 & $\mathrm{~b}-18.3$ & \pm 15 \\
\hline Chromium & $\mathrm{b}-16.8$ & $\mathrm{~b}-19.9$ & $\mathrm{~b}-22.1$ & $\mathrm{~b}-9.2$ & $\mathrm{a}-1.5$ & $\mathrm{~b}-8.1$ & $\mathrm{~b}-6.2$ & b15.6 & $\mathrm{b}-12.4$ & b34.0 & $b-6.7$ & b 25.5 & b25.4 & b1.6 & \pm 50 \\
\hline Cobalt & -68.1 & -65.1 & -68.8 & -55.3 & $\mathrm{~b}-35.0$ & $\mathrm{~b}-30.3$ & $\mathrm{~b}-11.3$ & b7.9 & ${ }^{\mathrm{a}} 1.0$ & b 19.3 & b49.5 & b 9.2 & 54.3 & $\mathrm{~b}-6.4$ & \pm 50 \\
\hline Copper & 101.8 & b38.4 & $\mathrm{a}-0.4$ & b30.6 & b38.9 & ND & $\mathrm{b}-10.0$ & b0.7 & $\mathrm{b} 17.5$ & b30.2 & b11.6 & 60.6 & ND & b36.1 & \pm 50 \\
\hline Fluoride & ${ }^{\mathrm{b}} 0.2$ & ${ }^{\mathrm{a}} 0.0$ & $\mathrm{~b}-3.9$ & $\mathrm{~b}-0.2$ & ${ }^{\mathrm{b}} 0.4$ & $\mathrm{~b}-3.4$ & $\mathrm{~b}-2.5$ & $\mathrm{~b}-1.6$ & $\mathrm{~b}-2.7$ & $\mathrm{~b}-5.3$ & $\mathrm{~b} 0.7$ & $\mathrm{~b}-2.0$ & ${ }^{\mathrm{b}} 0.4$ & $\mathrm{~b}-1.5$ & \pm 15 \\
\hline Iron & ND & 118.7 & ND & $\mathrm{ND}$ & $\mathrm{b}-14.1$ & $\mathrm{~b}-19.4$ & $\mathrm{~b}-9.4$ & b17.9 & $\mathrm{b}-24.7$ & 51.1 & b6.8 & b9.1 & $\mathrm{a}-0.4$ & b28.7 & \pm 25 \\
\hline Lead & ND & ND & ND & ND & ND & ND & ND & ND & ND & ND & ND & ND & ND & ND & -- \\
\hline Lithium & $\mathrm{b}-11.3$ & $\mathrm{~b}-10.8$ & $\mathrm{~b}-13.6$ & $\mathrm{~b}-13.6$ & $\mathrm{~b}-9.5$ & $\mathrm{~b}-11.9$ & $\mathrm{~b}-15.5$ & $\mathrm{~b}-13.5$ & $\mathrm{~b}-16.1$ & $\mathrm{~b}-13.2$ & $\mathrm{a}-6.4$ & $\mathrm{~b}-14.5$ & $\mathrm{~b}-10.0$ & $\mathrm{~b}-12.3$ & \pm 25 \\
\hline Magnesium & $\mathrm{b}-9.0$ & $\mathrm{~b}-8.5$ & $\mathrm{~b}-13.1$ & $\mathrm{~b}-11.7$ & b -10.9 & $\mathrm{~b}-9.0$ & $\mathrm{~b}-11.8$ & $\mathrm{~b}-9.1$ & $\mathrm{~b}-10.6$ & $\mathrm{~b}-11.4$ & $\mathrm{~b}-10.3$ & $\mathrm{~b}-8.2$ & $\mathrm{a}-7.9$ & $\mathrm{~b}-10.1$ & \pm 15 \\
\hline Manganese & -146.5 & -124.8 & -125.8 & -110.7 & c -80.6 & $c-80.3$ & $\mathrm{~b}-43.7$ & $\mathrm{~b}-19.6$ & $\mathrm{~b}-34.0$ & a -0.9 & b49.3 & $\mathrm{b}-11.1$ & 63.8 & $\mathrm{~b}-32.1$ & \pm 50 \\
\hline Molybdenum & b4.3 & $\mathrm{b}-1.3$ & $\mathrm{~b}-10.2$ & ${ }^{\mathrm{a}} 0.2$ & $\mathrm{~b}-1.4$ & b9.3 & ${ }^{\mathrm{b}} 0.3$ & b 16.6 & b5.4 & b9.1 & b4.9 & b32.4 & b26.9 & b8.1 & \pm 50 \\
\hline Nickel & 29.2 & b23.6 & b 14.3 & ${ }^{\mathrm{a}} 12.6$ & b20.7 & 27.3 & b 19.4 & 35.3 & 29.4 & 36.6 & 47.5 & 30.5 & b23.3 & b27.4 & \pm 25 \\
\hline Potassium & b4.4 & b5.5 & $\mathrm{a}-1.1$ & b1.9 & b4.3 & b5.5 & b1.7 & b4.4 & b2.3 & b3.2 & $\mathrm{b} 2.5$ & b3.0 & b3.1 & b3.1 & \pm 15 \\
\hline Selenium & $\mathrm{b}-24.1$ & $\mathrm{~b}-27.0$ & $\mathrm{~b}-30.5$ & $\mathrm{~b}-28.4$ & b -29.4 & $\mathrm{~b}-24.1$ & $\mathrm{~b}-26.1$ & $\mathrm{~b}-25.1$ & $\mathrm{~b}-27.9$ & $\mathrm{~b}-27.7$ & $\mathrm{~b}-22.4$ & $\mathrm{a}-17.5$ & $\mathrm{~b}-22.5$ & $\mathrm{~b}-25.5$ & \pm 50 \\
\hline Silica & $\mathrm{b}-2.4$ & $\mathrm{~b}-2.8$ & $b-7.1$ & $\mathrm{~b}-5.6$ & $\mathrm{~b}-5.1$ & $\mathrm{~b}-3.5$ & $\mathrm{~b}-5.5$ & $\mathrm{a}-2.4$ & $\mathrm{~b}-5.1$ & $\mathrm{~b}-4.1$ & $\mathrm{~b}-5.3$ & $b-4.3$ & $b-3.3$ & $\mathrm{~b}-4.3$ & \pm 50 \\
\hline Sodium & $\mathrm{b}-7.6$ & a -7.6 & $\mathrm{~b}-12.1$ & $\mathrm{~b}-10.2$ & $\mathrm{~b}-10.0$ & $\mathrm{~b}-7.9$ & $\mathrm{~b}-11.1$ & $\mathrm{~b}-8.2$ & $\mathrm{~b}-9.5$ & $\mathrm{~b}-10.3$ & b -9.9 & $\mathrm{~b}-8.7$ & $\mathrm{~b}-8.1$ & $\mathrm{~b}-9.3$ & \pm 15 \\
\hline Strontium & $\mathrm{a}-8.6$ & $\mathrm{~b}-9.4$ & $\mathrm{~b}-12.2$ & $\mathrm{~b}-12.2$ & b -11.1 & $\mathrm{~b}-8.6$ & $\mathrm{~b}-12.0$ & $\mathrm{~b}-9.5$ & b -10.3 & b -11.1 & $\mathrm{~b}-12.6$ & $\mathrm{~b}-9.5$ & $\mathrm{~b}-8.8$ & $\mathrm{~b}-10.5$ & \pm 25 \\
\hline
\end{tabular}


Table 6. Relative percent difference (RPD) between pump and passive sampling results at sentinel well SO-1A near Kirtland Air Force Base, Albuquerque, New Mexico.Continued

$\left[\%\right.$, percent; \pm , plus or minus; ND, passive or pump result was not detected and RPD could not be calculated; --, not calculated; $\delta^{18} \mathrm{O}$, stable isotope of oxygen; $\delta^{2} \mathrm{H}$, stable isotope of hydrogen. Samplers are listed shallow (Sampler 1) to deep (Sampler 13). Dark green shaded areas show results that were within the RPD criteria (Imbrigiotta and Harte, 2020) in last column. Gray shaded areas show the minimum RPD, for each analyte, that met the criteria in last column. Yellow shaded areas are results that did not meet the RPD criteria but were within the estimated sampling variability]

\begin{tabular}{|c|c|c|c|c|c|c|c|c|c|c|c|c|c|c|c|}
\hline \multirow[b]{2}{*}{ Analyte } & \multirow[b]{2}{*}{$\begin{array}{c}\text { Sampler } \\
1\end{array}$} & \multirow[b]{2}{*}{$\begin{array}{c}\text { Sampler } \\
2\end{array}$} & \multicolumn{12}{|c|}{ Relative percent difference (\%) } & \multirow{2}{*}{$\begin{array}{c}\text { RPD } \\
\text { criteria } \\
(\%)\end{array}$} \\
\hline & & & $\begin{array}{c}\text { Sampler } \\
3\end{array}$ & $\begin{array}{c}\text { Sampler } \\
4\end{array}$ & $\begin{array}{c}\text { Sampler } \\
\mathbf{5}\end{array}$ & $\begin{array}{c}\text { Sampler } \\
6\end{array}$ & $\begin{array}{c}\text { Sampler } \\
7\end{array}$ & $\begin{array}{c}\text { Sampler } \\
8\end{array}$ & $\begin{array}{c}\text { Sampler } \\
9\end{array}$ & $\begin{array}{c}\text { Sampler } \\
10\end{array}$ & $\begin{array}{c}\text { Sampler } \\
11\end{array}$ & $\begin{array}{c}\text { Sampler } \\
12\end{array}$ & $\begin{array}{c}\text { Sampler } \\
13\end{array}$ & $\begin{array}{l}\text { Sampler } \\
\text { average }\end{array}$ & \\
\hline Sulfate & $\mathrm{b}-8.6$ & $\mathrm{~b}-9.7$ & $\mathrm{~b}-12.9$ & $\mathrm{~b}-11.6$ & $b-10.5$ & $\mathrm{~b}-8.1$ & $\mathrm{~b}-10.7$ & $\mathrm{~b}-9.1$ & $\mathrm{~b}-7.9$ & $\mathrm{~b}-9.5$ & $b-6.9$ & $\mathrm{a}-6.3$ & $b-6.7$ & $b-9.1$ & \pm 15 \\
\hline Uranium & $\mathrm{b}-2.7$ & $\mathrm{~b}-2.2$ & $\mathrm{~b}-6.4$ & $\mathrm{~b}-4.0$ & $b-4.6$ & $\mathrm{~b}-2.4$ & $\mathrm{~b}-4.4$ & $\mathrm{~b}-2.8$ & $\mathrm{~b}-3.5$ & $\mathrm{~b}-4.1$ & b8.2 & $b-2.9$ & $\mathrm{a}-1.3$ & $\mathrm{~b}-2.5$ & \pm 50 \\
\hline Vanadium & $\mathrm{b}-12.8$ & b -13.1 & $\mathrm{~b}-12.7$ & $\mathrm{~b}-7.7$ & $\mathrm{a}-7.4$ & b -12.7 & b -13.8 & b -14.3 & b -14.6 & $\mathrm{~b}-18.5$ & b -19.7 & b -25.6 & $\mathrm{~b}-17.7$ & b -14.6 & \pm 50 \\
\hline Zinc & ND & ND & ND & $\mathrm{ND}$ & ND & ND & ND & ND & ND & ND & ND & ND & ND & ND & -- \\
\hline$\delta^{18} \mathrm{O}$ & $\mathrm{b}-0.4$ & $\mathrm{~b}-0.8$ & $\mathrm{~b}-2.5$ & $\mathrm{~b}-3.2$ & $\mathrm{~b}-1.2$ & $\mathrm{~b}-0.7$ & $\mathrm{~b}-0.9$ & $\mathrm{a}-0.3$ & $\mathrm{~b}-1.0$ & $\mathrm{~b}-1.2$ & $\mathrm{~b}-1.7$ & $\mathrm{~b}-1.3$ & $\mathrm{~b} 0.4$ & $\mathrm{~b}-1.1$ & \pm 15 \\
\hline$\delta^{2} \mathrm{H}$ & $a-0.6$ & $\mathrm{~b}-1.1$ & $\mathrm{~b}-3.1$ & $b-3.2$ & $\mathrm{~b}-2.0$ & $\mathrm{~b}-1.3$ & $\mathrm{~b}-2.2$ & $\mathrm{~b}-1.3$ & $\mathrm{~b}-0.9$ & $b-1.5$ & $\mathrm{~b}-0.8$ & $\mathrm{~b}-0.8$ & $\mathrm{~b}-0.8$ & $\mathrm{~b}-1.5$ & \pm 15 \\
\hline
\end{tabular}

aMinimum RPD that met the RPD criteria.

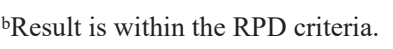

cResult did not meet RPD criteria but was within the estimated sampling variability. 
Table 7. Relative percent difference (RPD) between pump and passive sampling results at sentinel well TR-1A near Kirtland Air Force Base, Albuquerque, New Mexico.

$\left[\%\right.$, percent; NA, data was not available; \pm , plus or minus; ND, passive or pump result was not detected and RPD could not be calculated; --, not calculated; $\delta^{18} \mathrm{O}$, stable isotope of oxygen; $\delta^{2} \mathrm{H}$, stable isotope of

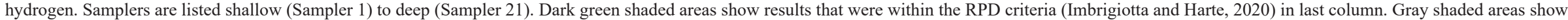
the minimum RPD, for each analyte, that met the criteria in last column. Yellow shaded areas are results that did not meet the RPD criteria but were within the estimated sampling variability]

\section{Relative percent difference $(\%)$}

Analyte Sam- Sam- Sam- Sam- Sam- Sam- Sam- Sam- Sam- Sam- Samp- Sam- Sam- Sam- Sam- Sam- Sam- Sam- Sam- Sam- Sam- Sam

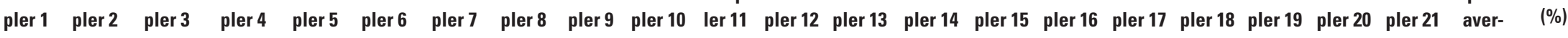

\begin{tabular}{|c|c|c|c|c|c|c|c|c|c|c|c|c|c|c|c|c|c|c|c|c|c|c|c|}
\hline & & & & & & & & & & & & & & & & & & & & & & & \\
\hline H & A & a2.7 & a 2.7 & a 2.7 & a 1.3 & a3.5 & a 0.5 & a 1.7 & a 3.4 & ${ }^{\mathrm{a}} 0.8$ & b 0.0 & -0.8 & a 0.9 & $a-0.8$ & a 0.5 & aа 0.8 & a 0.5 & $\mathrm{a}-0.3$ & $\mathrm{a}-0.7$ & ${ }^{\mathrm{a}} 0.1$ & a 2.1 & $\mathrm{a} 1.1$ & \pm 15 \\
\hline $\mathrm{du}$ & $\mathrm{NA}$ & a 5.0 & $\mathrm{~b}-1.2$ & a5.3 & a 5.9 & a3.8 & a6.4 & a 7.3 & ${ }^{\mathrm{a}} 6.5$ & ${ }^{\mathrm{a}} 6.4$ & ${ }^{\mathrm{a}} 6.0$ & a9.0 & -23.7 & a4.6 & ${ }^{\mathrm{a}} 6.8$ & a 7.5 & a5.7 & ${ }^{\mathrm{a}} 6.8$ & a 5.7 & a 4.4 & a -9.9 & 3.7 & \pm 15 \\
\hline ka & & 39.9 & 39.9 & & 387 & 307 & & 40.5 & 38.7 & & 38.2 & 36.3 & 38.2 & 366 & 345 & 345 & 24 & 38 ? & 30.7 & & NA & 35.7 & \pm 15 \\
\hline un & 1561 & ND & ND & & ND & ND & & & & & ND & ND & ND & ND & tris & 170 & 170 & 170 & 政 & & ND & & \pm 25 \\
\hline $\mathrm{ti}$ & a32.5 & ${ }^{\mathrm{a}} 11.0$ & a -14.0 & a33.7 & ${ }^{\mathrm{a}} 12.2$ & a -4.3 & a 17.3 & & 50.8 & a 32.0 & a28.0 & a5.8 & a 20.8 & a10.7 & a -7.3 & a 3.8 & a -9.6 & $\mathrm{a}-23.9$ & $\mathrm{a}-27.0$ & $\mathrm{a}-33.2$ & b -1.9 & ${ }^{\mathrm{a}} 12.2$ & \pm 50 \\
\hline se & -40.9 & -37.5 & -69.9 & -51.1 & -53.4 & -40.2 & -37.1 & a -7.4 & $\mathrm{a}-15.5$ & $\mathrm{a}-15.8$ & $\mathrm{a}-5.5$ & a -11.3 & $\mathrm{a}-16.8$ & a -13.6 & $\mathrm{a}-3.0$ & ${ }^{\mathrm{b}} 0.9$ & ${ }^{\mathrm{a}} 1.4$ & a -9.3 & $\mathrm{a}-1.2$ & a -6.9 & $\mathrm{a}-1.1$ & -19.0 & \pm 25 \\
\hline riur & -26.3 & -22.9 & -26.0 & -30.3 & -30.4 & -29.7 & -28.2 & -32.5 & -32.5 & -30.6 & -31.5 & -30.7 & -32.9 & -36.0 & -33.6 & -35.3 & -35.6 & -31.7 & -32.8 & -32.8 & -47.7 & -31.8 & \pm 25 \\
\hline cark & b11.6 & 40.2 & 40.4 & 36.0 & 39.1 & 39.8 & 33.7 & 40.9 & 39.0 & 37.3 & 38.6 & 36.7 & 38.6 & 37.1 & 34.9 & 34.9 & 35.1 & 38.6 & 31.1 & 34.0 & NA & 36.1 & \pm 15 \\
\hline ron & 17.8 & $\mathrm{a}-9.1$ & a -8.3 & -12.9 & $\mathrm{a}-15.0$ & $\mathrm{a}-7.8$ & -14.9 & $\mathrm{a}-7.0$ & -6.5 & a -9.9 & -12.3 & $\mathrm{~b}-6.3$ & -13.8 & $a-6.6$ & $\mathrm{a}-8.8$ & $\mathrm{a}-7.8$ & $a-10.0$ & $a-7.8$ & $a-9.9$ & a -9.0 & $\mathrm{a}-12.3$ & -10.1 & \pm 25 \\
\hline $\mathrm{mi}$ & -12.7 & $\mathrm{a}-10.2$ & $\mathrm{~b}-10.0$ & -14.1 & $\mathrm{a}-13.5$ & $\mathrm{a}-10.1$ & -11.3 & $a-10.3$ & $\mathrm{a}-10.6$ & $\mathrm{a}-12.7$ & $\mathrm{a}-11.1$ & $\mathrm{a}-10.4$ & a -10.9 & $\mathrm{a}-12.3$ & $\mathrm{a}-11.9$ & $\mathrm{a}-11.1$ & $\mathrm{a}-12.5$ & $\mathrm{a}-11.6$ & $\mathrm{a}-12.2$ & $\mathrm{a}-14.5$ & $\mathrm{a}-19.6$ & $\mathrm{a}-12.0$ & 50 \\
\hline lci & ${ }^{a} 5.2$ & ${ }^{\mathrm{a}} 10.1$ & ${ }^{\mathrm{a}} 11.0$ & a7.6 & a5.8 & a 10.6 & a 7.6 & ${ }^{\mathrm{a}} 10.2$ & a 8.5 & a7.8 & a9.7 & a 11.3 & a10.9 & a8.9 & a8.9 & ${ }^{\mathrm{a}} 10.5$ & ${ }^{\mathrm{a}} 10.2$ & a 10.9 & a9.8 & a8.7 & ${ }^{b} 1.7$ & 8.9 & \pm 15 \\
\hline & -10.9 & b -8.2 & a -8.8 & $\mathrm{a}-12.6$ & -12.2 & $\mathrm{a}-8.7$ & -10.7 & $\mathrm{a}-8.9$ & $\mathrm{a}-9.3$ & $\mathrm{a}-10.9$ & $\mathrm{a}-9.6$ & a -8.9 & a -9.2 & $\mathrm{a}-11.5$ & $\mathrm{a}-10.6$ & a -9.8 & $\mathrm{a}-10.4$ & a -9.9 & $\mathrm{a}-11.1$ & $\mathrm{a}-12.5$ & $\mathrm{a}-17.7$ & -10.6 & \pm 15 \\
\hline ro & & ND & ND & ND & ND & ND & ND & ND & ND & ND & ND & ND & ND & ND & ND & ND & ND & ND & ND & ND & & ND & \\
\hline bal & 45.8 & $\mathrm{a}-3.0$ & $\mathrm{a}-6.5$ & $\mathrm{a}-12.4$ & ${ }^{\mathrm{b}} 0.5$ & c -56.7 & -16.0 & $\mathrm{a}-21.5$ & -99.4 & c -67.5 & a 0.8 & -69.2 & -16.6 & $\mathrm{a}-14.8$ & $\mathrm{a}-17.3$ & ${ }^{\mathrm{a}} 18.1$ & $\mathrm{a}-22.9$ & -94.2 & -17.1 & -100.9 & -15.9 & -30.6 & \pm 50 \\
\hline $\mathrm{pp}$ & & ND & ND & ND & ND & ND & ND & ND & ND & & ND & ND & ND & ND & ND & ND & & NVD & & ND & ND & ND & 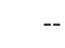 \\
\hline 10 & -65.6 & -60.7 & -60.2 & -64.5 & -65.6 & -59.1 & -60.7 & -60.7 & -59.6 & -59.6 & -58.6 & -55.5 & -56.0 & -58.1 & -56.0 & -54.5 & -47.6 & -54.5 & -54.5 & -56.0 & -61.8 & -58.5 & \pm 15 \\
\hline n & 86.1 & 183.7 & 175.7 & 171.8 & 175.6 & 164.4 & 182.2 & 161.5 & 168.5 & 177.7 & 174.9 & 172.6 & 167.4 & 172.1 & 175.3 & 154.9 & 169.7 & 170.2 & 170.1 & 174.6 & 150.9 & 173.8 & \pm 25 \\
\hline $\mathrm{ad}$ & ND & ND & ND & ND & ND & ND & ND & ND & ND & ND & ND & ND & ND & ND & ND & ND & ND & ND & ND & ND & ND & ND & $\ldots$ \\
\hline thium & $\mathrm{a}-1.1$ & a 7.1 & a8.6 & a2.6 & a 1.5 & a 8.0 & $\mathrm{~b} 0.0$ & a 8.3 & a8.1 & 2.4 & a2.9 & a 4.0 & a2.0 & a 6.9 & a 4.0 & 3.4 & a 2.3 & a 4.7 & 2.5 & a2.4 & a 0.9 & a 3.9 & \pm 25 \\
\hline aonesi & a2.6 & a5.6 & a6.7 & a 4.1 & b 1.3 & a 7.4 & a3.9 & a 7.0 & a5.5 & a3.9 & a6.7 & a 7.8 & a7.4 & a 5.5 & a5.5 & a 7.0 & ${ }^{\mathrm{a}} 6.4$ & a7.3 & ${ }^{\mathrm{a}} 6.5$ & a5.1 & $\mathrm{a}-1.5$ & 5.3 & \pm 15 \\
\hline - & 57.2 & 64.4 & 64.8 & 61.4 & 59.6 & 64.4 & 61.2 & 65.8 & 63.3 & 62.1 & 65.4 & 63.1 & 500 & 61.6 & 61.2 & 62.9 & 611 & 622 & 500 & 582 & 53.7 & 61.6 & \pm 25 \\
\hline & 85.4 & 102.0 & 92.3 & 101.0 & 97.9 & 104.0 & 105.3 & 108.1 & 106.9 & 105.5 & 106.7 & 105.0 & 108.8 & 115.8 & 106.8 & 107.5 & 107.0 & 104.7 & 106.0 & 104.7 & 103.8 & 104.4 & \pm 25 \\
\hline (N) & -138.8 & -149.4 & -156.7 & -132.0 & -129.8 & -140.4 & -123.3 & -117.5 & -119.2 & -117.7 & -109.6 & -121.9 & -109.6 & -101.0 & -92.3 & -100.0 & -89.3 & -96.1 & -74.3 & -80.8 & -16.9 & -106.9 & \pm 50 \\
\hline tassiuntin & 20.4 & 18.3 & 19.8 & a 13.8 & 16.1 & 17.4 & a13.9 & 20.6 & 19.4 & a 14.2 & 16.2 & 17.4 & 19.2 & 16.6 & 17.9 & 17.9 & a12.9 & a13.9 & 15.7 & ${ }^{\mathrm{a}} 12.7$ & b9.7 & 16.4 & \pm 15 \\
\hline lenium & ND & ND & -192.2 & -192.4 & -191.8 & -191.6 & -191.8 & -186.2 & -189.6 & -189.0 & -188.7 & -190.1 & -189.8 & -190.8 & -190.5 & -190.1 & -190.9 & -190.6 & -190.1 & -189.4 & -189.1 & -190.2 & \pm 50 \\
\hline lica & $\mathrm{a}-0.1$ & $\mathrm{a}-0.8$ & $\mathrm{a}-0.5$ & $\mathrm{a}-3.1$ & $\mathrm{a}-1.4$ & a 0.9 & $\mathrm{a}-2.2$ & a -0.7 & a -2.6 & $\mathrm{a}-0.2$ & $\mathrm{a}-2.1$ & ${ }^{\mathrm{b}} 0.0$ & $\mathrm{a}-1.3$ & $\mathrm{a}-3.2$ & $\mathrm{a}-3.5$ & $\mathrm{a}-2.0$ & $\mathrm{a}-1.8$ & $\mathrm{a}-2.0$ & $\mathrm{a}-2.9$ & $\mathrm{a}-4.6$ & $\mathrm{a}-13.5$ & 2.2 & \pm 25 \\
\hline dium & 27.9 & ${ }^{\mathrm{a}} 11.1$ & ${ }^{\mathrm{a}} 13.9$ & a 11.1 & a9.6 & a9.9 & a7.4 & 19.4 & 15.2 & ${ }^{\mathrm{a}} 10.2$ & ${ }^{\mathrm{a}} 14.1$ & ${ }^{\mathrm{a}} 14.1$ & ${ }^{\mathrm{a}} 13.1$ & a 10.6 & a9.1 & a 10.9 & ${ }^{\mathrm{a}} 5.0$ & a9.3 & a 8.4 & ${ }^{\mathrm{a}} 6.6$ & $\mathrm{~b}-0.2$ & ${ }^{\mathrm{a}} 11.4$ & \pm 15 \\
\hline ontium & ${ }^{2} 4.2$ & ${ }^{\mathrm{a}} 10.4$ & a 10.4 & ${ }^{a} 6.7$ & ${ }^{a} 4.2$ & a 10.5 & ${ }^{\mathrm{a}} 6.4$ & ${ }^{\mathrm{a}} 10.0$ & a8.9 & a 7.6 & a 8.1 & a9.5 & a 10.4 & a8.4 & a8.2 & a9. 2 & a 8.5 & a9.9 & a9.1 & a8.1 & ${ }^{\mathrm{b}} 0.2$ & a8.1 & \pm 25 \\
\hline
\end{tabular}


Table 7. Relative percent difference (RPD) between pump and passive sampling results at sentinel well TR-1A near Kirtland Air Force Base, Albuquerque, New Mexico.-Continued

[\%, percent; NA, data was not available; \pm , plus or minus; ND, passive or pump result was not detected and RPD could not be calculated; --, not calculated; $\delta^{18} \mathrm{O}$, stable isotope of oxygen; $\delta^{2} \mathrm{H}$, stable isotope of hydrogen. Samplers are listed shallow (Sampler 1) to deep (Sampler 21). Dark green shaded areas show results that were within the RPD criteria (Imbrigiotta and Harte, 2020) in last column. Gray shaded areas show the minimum RPD, for each analyte, that met the criteria in last column. Yellow shaded areas are results that did not meet the RPD criteria but were within the estimated sampling variability]

\begin{tabular}{|c|c|c|c|c|c|c|c|c|c|c|c|c|c|c|c|c|c|c|c|c|c|c|c|}
\hline \multirow[b]{2}{*}{ Analyte } & \multicolumn{22}{|c|}{ Relative percent difference (\%) } & \multirow[b]{2}{*}{$\begin{array}{c}\text { RPD } \\
\text { criteria } \\
(\%)\end{array}$} \\
\hline & $\begin{array}{l}\text { Sam- } \\
\text { pler } 1\end{array}$ & $\begin{array}{l}\text { Sam- } \\
\text { pler } 2\end{array}$ & $\begin{array}{l}\text { Sam- } \\
\text { pler } 3\end{array}$ & $\begin{array}{l}\text { Sam- } \\
\text { pler } 4\end{array}$ & $\begin{array}{l}\text { Sam- } \\
\text { pler } 5\end{array}$ & $\begin{array}{l}\text { Sam- } \\
\text { pler } 6\end{array}$ & $\begin{array}{l}\text { Sam- } \\
\text { pler } 7\end{array}$ & $\begin{array}{l}\text { Sam- } \\
\text { pler } 8\end{array}$ & $\begin{array}{l}\text { Sam- } \\
\text { pler } 9\end{array}$ & $\begin{array}{c}\text { Sam- } \\
\text { pler } 10\end{array}$ & $\begin{array}{l}\text { Samp- } \\
\text { ler } 11\end{array}$ & $\begin{array}{c}\text { Sam- } \\
\text { pler } 12\end{array}$ & $\begin{array}{c}\text { Sam- } \\
\text { pler } 13\end{array}$ & $\begin{array}{c}\text { Sam- } \\
\text { pler } 14\end{array}$ & $\begin{array}{c}\text { Sam- } \\
\text { pler } 15\end{array}$ & $\begin{array}{c}\text { Sam- } \\
\text { pler } 16\end{array}$ & $\begin{array}{c}\text { Sam- } \\
\text { pler } 17\end{array}$ & $\begin{array}{c}\text { Sam- } \\
\text { pler } 18\end{array}$ & $\begin{array}{c}\text { Sam- } \\
\text { pler } 19\end{array}$ & $\begin{array}{c}\text { Sam- } \\
\text { pler } 20\end{array}$ & $\begin{array}{c}\text { Sam- } \\
\text { pler } 21\end{array}$ & $\begin{array}{c}\text { Sam } \\
\text { pler } \\
\text { aver- } \\
\text { age }\end{array}$ & \\
\hline Sulfate & -56.9 & -49.4 & -49.8 & -54.2 & -54.3 & -45.3 & -50.3 & -45.1 & -46.4 & -46.2 & -42.8 & -41.9 & -42.7 & -45.2 & -42.2 & -40.8 & -40.6 & -39.7 & -40.2 & -41.1 & -46.2 & -45.7 & \pm 15 \\
\hline Uranium & -136.4 & -141.4 & -147.9 & -143.3 & -148.0 & -137.2 & -136.9 & -118.6 & -122.9 & -121.0 & -115.5 & -118.8 & -114.5 & -116.5 & -113.6 & -109.2 & -103.6 & -110.1 & -107.0 & -106.1 & -104.0 & -121.9 & \pm 50 \\
\hline Vanadium & -185.1 & -189.2 & -190.9 & -189.2 & -188.5 & -187.9 & -186.8 & -179.2 & -182.6 & -183.2 & -183.4 & -181.8 & -183.3 & -183.2 & -181.3 & -181.7 & -179.1 & -181.4 & -178.5 & -180.5 & -174.1 & -183.3 & \pm 50 \\
\hline Zinc & $\mathrm{a}-38.5$ & $\mathrm{~b}-22.5$ & ND & ND & ND & ND & ND & ND & ND & ND & ND & ND & ND & ND & ND & ND & ND & -44.0 & ND & ND & ND & -59.4 & \pm 50 \\
\hline$\delta^{18} \mathrm{O}$ & NA & $\mathrm{b}-0.6$ & $\mathrm{a}-2.0$ & $\mathrm{a}-3.5$ & $\mathrm{a}-3.2$ & $\mathrm{a}-1.6$ & $\mathrm{a}-2.4$ & $\mathrm{a}-1.4$ & $\mathrm{a}-1.8$ & $\mathrm{a}-2.0$ & $\mathrm{a}-1.3$ & $\mathrm{a}-1.1$ & $\mathrm{a}-1.1$ & $a-2.7$ & $\mathrm{a}-1.5$ & $\mathrm{a}-0.9$ & $\mathrm{a}-1.3$ & $\mathrm{a}-1.5$ & $\mathrm{a}-1.1$ & $\mathrm{a}-1.8$ & NA & $\mathrm{a}-2.0$ & \pm 15 \\
\hline$\delta^{2} \mathrm{H}$ & NA & $a-1.8$ & $\mathrm{a}-1.0$ & $\mathrm{a}-4.1$ & $\mathrm{a}-4.2$ & $\mathrm{a}-1.6$ & $\mathrm{a}-2.4$ & $\mathrm{a}-1.7$ & $a-1.7$ & $\mathrm{a}-2.0$ & $\mathrm{a}-1.7$ & $\mathrm{~b}-0.4$ & $\mathrm{a}-1.1$ & $\mathrm{a}-3.8$ & $\mathrm{a}-2.1$ & $\mathrm{a}-1.1$ & $\mathrm{a}-2.4$ & $\mathrm{a}-2.1$ & $\mathrm{a}-1.7$ & $\mathrm{a}-1.3$ & NA & $\mathrm{a}-1.7$ & \pm 15 \\
\hline
\end{tabular}

${ }^{a}$ Result is within the RPD criteria.

${ }^{b}$ Minimum RPD that met the RPD criteria.

cResult did not meet RPD criteria but was within the estimated sampling variability. 
Table 8. Relative percent difference (RPD) between pump and passive sampling results at sentinel well VA-1A, Kirtland Air Force Base, Albuquerque, New Mexico.

[\%, percent; \pm , plus or minus; ND, passive or pump result was not detected and RPD could not be calculated; NA, data were not available; --, not calculated; $\delta^{18} \mathrm{O}$, stable isotope of oxygen; $\delta^{2} \mathrm{H}$, stable isotope of hydrogen. Samplers are listed shallow (Sampler 1) to deep (Sampler 8). Dark green shaded areas show results that were within the RPD criteria (Imbrigiotta and Harte, 2020) in last column. Gray shaded areas show the minimum RPD, for each analyte, that met the criteria in last column. Yellow shaded areas are results that did not meet the RPD criteria but were within the estimated sampling variability]

\begin{tabular}{|c|c|c|c|c|c|c|c|c|c|c|}
\hline \multirow[b]{2}{*}{ Analyte } & \multicolumn{9}{|c|}{ Relative percent difference (\%) } & \multirow{2}{*}{$\begin{array}{c}\text { RPD } \\
\text { criteria } \\
(\%)\end{array}$} \\
\hline & Sampler 1 & Sampler 2 & Sampler 3 & Sampler 4 & Sampler 5 & Sampler 6 & Sampler 7 & Sampler 8 & $\begin{array}{l}\text { Sampler } \\
\text { average }\end{array}$ & \\
\hline $\mathrm{pH}$ & $\mathrm{a}-2.6$ & $\mathrm{a}-0.4$ & $\mathrm{a}-0.5$ & $\mathrm{a}-0.4$ & $\mathrm{~b}^{\mathrm{b}} 0.0$ & $a-0.3$ & $\mathrm{a}-0.9$ & ${ }^{\mathrm{a}} 0.8$ & $\mathrm{a}-0.5$ & \pm 15 \\
\hline $\begin{array}{l}\text { Specific } \\
\text { conductance }\end{array}$ & ${ }^{\mathrm{a}} 1.8$ & $\mathrm{~b}-0.5$ & a 8.1 & ${ }^{\mathrm{a}} 12.8$ & ${ }^{\mathrm{a}} 13.1$ & ${ }^{\mathrm{a}} 13.2$ & ${ }^{\mathrm{a}} 12.0$ & a 16.5 & a9.8 & \pm 15 \\
\hline Alkalinity & 15.4 & 28.7 & 27.4 & 25.2 & 32.9 & 25.2 & 31.1 & 40.7 & 28.6 & \pm 15 \\
\hline Aluminum & $\mathrm{ND}$ & ND & ND & ND & ND & ND & ND & ND & ND & -- \\
\hline Antimony & -60.0 & $\mathrm{c}-51.1$ & $c-57.9$ & $\mathrm{a}-34.7$ & $a-30.6$ & $\mathrm{~b}-7.6$ & $\mathrm{a}-28.5$ & $\mathrm{a}-12.2$ & $\mathrm{a}-33.9$ & \pm 50 \\
\hline Arsenic & -95.0 & -89.2 & -66.9 & -58.7 & -52.6 & a -47.8 & $\mathrm{~b}-45.7$ & -57.4 & -63.1 & \pm 50 \\
\hline Barium & $\mathrm{a}-20.0$ & $\mathrm{~b}-17.9$ & a -22.7 & a -20.4 & $\mathrm{a}-24.9$ & a -23.8 & $\mathrm{a}-23.8$ & $\mathrm{a}-18.1$ & $\mathrm{a}-21.4$ & \pm 25 \\
\hline Bicarbonate & NA & 29.0 & 27.7 & 25.1 & 33.0 & 25.2 & 31.3 & 40.5 & 30.4 & \pm 15 \\
\hline Boron & ${ }^{\mathrm{a}} 0.3$ & a5.0 & $\mathrm{a} 10.1$ & $\mathrm{a} 10.3$ & $\mathrm{a} 11.3$ & $\mathrm{a} 12.5$ & $\mathrm{a} 12.0$ & a 17.9 & $\mathrm{a} 10.1$ & \pm 25 \\
\hline Bromide & $\mathrm{a}-11.3$ & a -4.2 & ${ }^{a} 4.5$ & a 8.8 & a 7.9 & ${ }^{\mathrm{a}} 1.2$ & ${ }^{\mathrm{a}} 1.2$ & ${ }^{\mathrm{b}} 0.0$ & ${ }^{\mathrm{a}} 1.4$ & \pm 50 \\
\hline Calcium & $\mathrm{a}-4.0$ & a -0.8 & a -2.7 & ${ }^{\mathrm{b}} 0.4$ & a 1.0 & a3.4 & a 2.1 & $\mathrm{a} 10.2$ & a1.3 & \pm 15 \\
\hline Chloride & a -3.6 & $\mathrm{~b}-0.3$ & a3.6 & a5.7 & a 6.9 & a 7.7 & ${ }^{\mathrm{a}} 6.0$ & a 7.7 & a 4.3 & \pm 15 \\
\hline Chromium & ND & ND & ND & ND & ND & ND & ND & ND & ND & -- \\
\hline Cobalt & ND & $\mathrm{a}-26.2$ & $c-65.3$ & $c-55.6$ & ${ }^{\mathrm{a}} 15.7$ & ${ }^{\mathrm{a}} 18.5$ & ND & $\mathrm{b}-9.5$ & $\mathrm{a}-15.8$ & \pm 50 \\
\hline Copper & ND & ND & ND & ND & ND & ND & ND & ND & ND & -- \\
\hline Fluoride & a -9.7 & $\mathrm{~b}-7.7$ & -15.8 & $\mathrm{a}-15.0$ & -17.1 & $a-14.4$ & -16.0 & -15.2 & $\mathrm{a}-13.8$ & \pm 15 \\
\hline Iron & -51.4 & -59.4 & $\mathrm{a}-1.1$ & a2.1 & 34.1 & 25.5 & 41.1 & 32.1 & a8.9 & \pm 25 \\
\hline Lead & ND & ND & ND & ND & $\mathrm{ND}$ & $\mathrm{ND}$ & ND & ND & ND & -- \\
\hline Lithium & 23.6 & ${ }^{\mathrm{a}} 10.0$ & ${ }^{\mathrm{a}} 16.5$ & ${ }^{\mathrm{a}} 17.4$ & a 17.6 & ${ }^{\mathrm{a}} 17.0$ & ${ }^{\mathrm{a}} 14.8$ & ${ }^{\mathrm{a}} 19.2$ & $\mathrm{a} 14.6$ & \pm 25 \\
\hline Magnesium & a -0.9 & a -1.6 & a -9.0 & a -6.0 & a -7.9 & a -4.8 & a -8.1 & b -0.1 & a -4.7 & \pm 15 \\
\hline Manganese & 24.3 & 32.3 & 77.4 & 85.5 & 90.9 & 88.8 & 87.7 & 99.8 & 76.9 & \pm 25 \\
\hline Molybdenum & -160.5 & -143.2 & -70.4 & -70.6 & -57.8 & -63.8 & -67.2 & -77.9 & -84.8 & \pm 50 \\
\hline Nickel & ND & ND & ND & ND & ND & ND & ND & c78.4 & 78.4 & \pm 50 \\
\hline Potassium & 38.8 & 34.6 & 38.6 & 39.7 & 39.7 & 40.0 & 37.7 & 45.8 & 39.4 & \pm 15 \\
\hline Selenium & c -84.4 & $\mathrm{~b}-40.7$ & c -120.1 & ND & ND & ND & ND & ND & -77.9 & \pm 50 \\
\hline Silica & $\mathrm{a}-1.3$ & ${ }^{\mathrm{a}} 0.6$ & $\mathrm{a}-0.4$ & ${ }^{\mathrm{a}} 2.3$ & ${ }^{\mathrm{a}} 0.9$ & ${ }^{\mathrm{a}} 1.9$ & $\mathrm{~b}-0.1$ & a3.5 & ${ }^{\mathrm{a}} 0.9$ & \pm 25 \\
\hline Sodium & b14.0 & 18.7 & 33.3 & 39.3 & 36.7 & 34.0 & 31.5 & 36.2 & 30.9 & \pm 15 \\
\hline Strontium & a -6.6 & $\mathrm{a}-4.7$ & $\mathrm{a}-9.0$ & a -7.0 & $\mathrm{a}-6.7$ & $\mathrm{a}-5.5$ & a -6.6 & $\mathrm{~b}-1.4$ & a -5.9 & \pm 25 \\
\hline Sulfate & -75.7 & -62.8 & -84.0 & -91.5 & -78.6 & -78.9 & -83.3 & -107.3 & -82.2 & \pm 15 \\
\hline Uranium & -154.4 & -126.5 & -157.5 & -162.7 & -163.1 & -163.1 & -166.4 & -172.5 & -157.8 & \pm 50 \\
\hline Vanadium & -142.1 & -146.2 & -172.0 & -176.1 & -177.6 & -172.2 & -173.8 & -176.3 & -166.5 & \pm 50 \\
\hline Zinc & $\mathrm{ND}$ & ND & ND & $\mathrm{ND}$ & ND & $\mathrm{ND}$ & $\mathrm{ND}$ & $\mathrm{ND}$ & $\mathrm{ND}$ & -- \\
\hline$\delta^{18} \mathrm{O}$ & $\mathrm{a}-1.4$ & $\mathrm{~b}-0.6$ & $\mathrm{a}-2.6$ & $\mathrm{a}-1.9$ & $\mathrm{a}-1.5$ & $\mathrm{a}-1.7$ & $\mathrm{a}-2.4$ & $\mathrm{a}-2.7$ & $\mathrm{a}-1.8$ & \pm 15 \\
\hline$\delta^{2} \mathrm{H}$ & $\mathrm{a}-1.6$ & $\mathrm{~b}-0.5$ & a -1.8 & $\mathrm{a}-2.2$ & a -2.3 & a -1.8 & a -2.6 & $\mathrm{a}-2.0$ & $\mathrm{a}-1.8$ & \pm 15 \\
\hline
\end{tabular}

aResult is within the RPD criteria.

${ }^{\mathrm{b}}$ Minimum RPD that met the RPD criteria.

cResult did not meet RPD criteria but was within the estimated sampling variability. 
Results for CC-1A (table 5) indicate that sampler 7 (497.30 ft bls) had the greatest number of analytes, 27 out of 34 , within the set criteria. Out of the seven analytes that did not meet the criteria, manganese ( -180.0 percent) and zinc (63.9 percent) exceeded the RPD criteria, and aluminum, cobalt, copper, iron, and lead were not calculated because results were below the detection limit; however, cobalt was detected in the pump sample (table 5). Sampler $8(499.80 \mathrm{ft}$ bls) had the greatest number of results for analytes with minimum RPD values: alkalinity, bicarbonate, bromide, chloride, cobalt, magnesium, sodium, and sulfate. Samplers $5(492.30 \mathrm{ft}$ bls) and 9 (502.30 ft bls) only had 23 analytes that met the RPD criteria, and the analytes that did not meet the criteria were alkalinity (sampler 9 only), antimony, bicarbonate (sampler 9 only), boron, lithium (sampler 5 only), manganese, and zinc. In more than one-half of the samplers, antimony and zinc concentrations were consistently higher in the passive samplers, and manganese concentrations were consistently higher in the pumped samples.

SO-1A had the greatest number of analytes, of all four sentinel wells, meeting the RPD criteria in two samplers (table 6). Samplers 7 (498.97 ft bls) and $11(508.97 \mathrm{ft} \mathrm{bls)} \mathrm{each}$ had 30 analytes that met the RPD criteria. The RPD criteria for chloride (-20.4 percent) was exceeded in sampler 7. In sampler 11, the RPD criteria was exceeded for nickel (47.5 percent). RPD was not calculated for samplers 7 and 11 for three analytes - aluminum, lead, and zinc - because the passive and pumped method results were below the detection limits. Sampler 13 (513.97 ft bls) had 27 analytes that met the RPD criteria but also had the most analytes with the lowest RPD, as evaluated for each analyte among all samplers: alkalinity, bicarbonate, calcium, iron, magnesium, and uranium. Sampler 1 only had 24 analytes that met the RPD criteria, and the analytes that did not meet the criteria were chloride, cobalt, copper, manganese, and nickel. In more than half of the RPD calculations, nickel concentrations were consistently higher in the passive samplers, and chloride and manganese concentrations were consistently higher in the pumped samples.

Three samplers in TR-1A (table 7) had the most analytes meeting the RPD criteria for the TR-1A samplers. Seventeen analytes in samplers 2 (464.95 ft bls), $17(502.45 \mathrm{ft} b l s)$, and 18 (504.95 ft bls) met the criteria. Analytes that met RPD criteria in these samplers included antimony, boron, bromide, calcium, chloride, lithium, magnesium, $\mathrm{pH}$, silica, specific conductance, sodium, strontium, $\delta^{2} \mathrm{H}$, and $\delta^{18} \mathrm{O}$. Samplers 2, 17 , and 18 had several analytes that exceeded the RPD criteria, including alkalinity, bicarbonate, fluoride, iron, manganese, molybdenum, nickel, sulfate, uranium, and vanadium. Iron, molybdenum, selenium, uranium, and vanadium had RPDs exceeding \pm 100 percent. In TR-1A, sampler 21 had the five analytes with minimum RPDs: antimony, calcium, potassium, sodium, and strontium. Sampler 1 only had 12 analytes that met the RPD criteria, and the analytes that did not meet the criteria included cobalt, fluoride, iron, manganese, molybdenum, nickel, potassium, sodium, sulfate, uranium, and vanadium. In more than one-half of the samplers, alkalinity, bicarbonate, iron, manganese, molybdenum, and potassium concentrations were consistently higher in the passive samplers, and arsenic, barium, fluoride, nickel, sulfate, uranium, and vanadium were consistently higher in the pumped samples.

For the samplers in VA-1A, sampler $6(634.81 \mathrm{ft} b l s)$ had the most analytes that met the RPD criteria (table 8). From samples obtained from sampler 6, 17 analytes met the RPD criteria; analytes that did not were alkalinity, bicarbonate, iron, manganese, molybdenum, potassium, sodium, sulfate, uranium, and vanadium. Uranium and vanadium had RPDs exceeding \pm 100 percent in samples from all samplers. Aluminum, chromium, copper, lead, and zinc had results below the detection limits for both methods, and RPDs were not calculated. Nickel and selenium had passive sampling results below the detection limits. In VA-1A, sampler 2 $(624.81 \mathrm{ft}$ bls) had the greatest number of analytes that had minimum RPD values: specific conductance, barium, chloride, fluoride, selenium, and stable isotopes $\left(\delta^{18} \mathrm{O}\right.$ and $\left.\delta^{2} \mathrm{H}\right)$. Samplers 3 and 8 only had 14 analytes, respectively, that met the RPD criteria, and the analytes that did not meet the criteria were specific conductance (sampler 8 only), alkalinity, arsenic, bicarbonate, cobalt (sampler 3 only), fluoride, iron (sampler 8 only), manganese, molybdenum, potassium, sodium, sulfate, uranium, and vanadium. In more than one-half of the samplers, alkalinity, bicarbonate, manganese, and sodium concentrations were consistently higher in the passive samplers, and arsenic, fluoride, iron, molybdenum, sulfate, uranium, and vanadium were consistently higher in the pumped samples.

\section{Method Variability}

The estimated variability for each sampling method (pump or passive) for each analyte, calculated in table 3, was to be used as an analytical tool to determine if the differences between the passive sampling method results and the pump sampling method results were caused only by the variation within each sampling method. To visualize the results and the associated method variability, plots of concentration versus depth were created with error bars that show the pump sampling method and passive sampling method variability (figs. 8-11).

Evaluation of the estimated variability (table 3 ) for the analytes that were not in agreement (that is, did not meet the RPD criteria or were not near the 1:1 line) between the two sampling methods was conducted. Only one analyte concentration (manganese), which had an RPD value that exceeded the set criteria, was within the sampling method variability. For CC-1A (fig. 8T, table 5) in sampler 10, the concentration of manganese was within the pump method variability, with the pumped sample having the higher concentration. SO-1A also had concentrations of manganese in samplers 5 and 6 that were within the method variability (fig. $9 \mathrm{~V}$, table 6) with the pumped sample having higher manganese concentrations. TR-1A had two cobalt concentrations that exceeded the RPD criteria but were within the method variability (fig. 10Q, 
table 7). VA-1A had concentrations of antimony (samplers 2 and 3 ) and selenium (samplers 1 and 3; fig. $11 M$ and $V$, table 8) with values higher in the pumped sample for both analytes. Cobalt concentration (samplers 3 and 4 ) and nickel concentrations (sampler 8) were primarily below detection limits for the passive samplers. Nickel was only detected in the last sampler and all other samplers had no nickel detected, therefore, the nickel concentrations are not plotted on figure 11.

\section{Potential Reasons for Differences Between Passive and Pump Samples}

When compared to previous studies that used passive samplers (Imbrigiotta and Harte, 2020), there were more analytes outside of the RPD criteria for this study. For pump methods in these previous studies, however, the wells were either purged at a low-flow rate (EON Products, Inc., 2021), or only one well volume was purged to stabilize field properties (USACE, 2016). The pump sampling method used in this study, in which three well volumes were purged at a rate $(0.7-1.25 \mathrm{gal} / \mathrm{min}$; table 1$)$ that is higher than a low-flow purge rate $(0.03-0.13 \mathrm{gal} / \mathrm{min}$; ASTM International, 2018), is likely one of the primary reasons for differences between passive and pump samples in this study. Imbrigiotta and Harte (2020) suggest that the physical differences between pumping-induced flow and ambient flow, which is associated with the passive sampling method, result in sampling water that is sourced from different zones of the aquifer, and this should be considered when comparing the two methods. Passive samplers are representative of the last several days of ambient flow before sampling, and pump samples are instantaneous samples from the induced flow. Additionally, the passive method measures concentrations over a discrete interval, which is the length of the sampler, and likely represents the water of that interval, whereas the pump method measures concentrations throughout the screened interval and surrounding aquifer (Divine and others, 2005).

Typically, when comparing passive and pump sampling methods where a large quantity of water is removed during purging, such as the present study where at least three well volumes were removed, Divine and others (2005) suggest calculating the flux-averaged concentrations by using the transmissivity and hydraulic conductivity of the discrete intervals where the passive samplers are located. The hydraulic properties of the discrete intervals are not known; however, based on drilling logs, they are assumed to be similar throughout the screened intervals of the sentinel wells, so the flux-averaged concentrations were not calculated. Given the heterogeneity of the aquifer and the presence of interbedded muds (Connell, 2006), when the sentinel wells are pumped, most of the water likely comes from the most conductive zones. Passive samplers draw water locally that may not be from the most conductive portion of the aquifer (Divine and others, 2005). Vertical flow could be induced by hydraulic head differences in the interbedded portions of the aquifer and could lead to mixing of water from different parts of the aquifer in passive samplers; however, vertical flow is not likely in the shallow sentinel wells (Myers and Friesz, 2019; Travis and Myers, 2019).

Another potential contributor to the lack of correspondence between passive and pump results are reduction/oxidation (redox) processes within the wells. Introducing oxygen into anoxic environments with oxygen-rich blank water may affect results. Introducing an oxygenated sampler into an anoxic environment can cause analytes to react when they diffuse into oxygenated water, which could cause chemicals to precipitate out and decrease concentrations of the analyte (Imbrigiotta and Harte, 2020). Borch and others (2010) also note that adding oxygenated water to a mixed redox environment likely explains the large differences of several elements related to redox processes, including iron and manganese (greater in the passive samplers) and molybdenum, selenium, sulfate, and uranium (greater in the pumped samples).

Redox processes were assigned in an Excel ${ }^{\circledR}$ Workbook developed by Jurgens and others (2009) using the framework devised by McMahon and Chapelle (2008). The redox processes were only determined for the pump samples, which had a complete dataset consisting of dissolved oxygen, nitrate, manganese, iron, and sulfate concentrations (table 9). The passive samples had incomplete datasets, lacked nitrate, and had indeterminate results that could not be calculated. The results for the pump samples indicate that $\mathrm{CC}-1 \mathrm{~A}$ and SO-1A had oxic water. TR-1A and VA-1A were categorized as having mixed (oxic-anoxic) water, with the redox process a mixture of oxygen-reducing and manganese-reducing groundwater. Field observations also support the differences in these sets of wells. At TR-1A and VA-1A, hydrogen sulfide odors were present in the passive samplers and pumped samples, and the passive samplers contained a visible black precipitate (fig. 12). The hydrogen sulfide odors are indicative of reducing conditions, and certain trace elements (selenium, molybdenum, and uranium) were higher in the pumped samples at TR-1A and VA-1A than in the passive samples. These conditions indicate that a sulfide precipitate was in the passive sampler bags (Smith, 2007). Additionally, adding oxygenated water to the mixed redox environment of the TR-1A and VA-1A wells, which have $\mathrm{pH}$ values ranging from 7.55 to 7.98 , could also produce a manganese precipitate based on the Eh-pH diagram for manganese (fig. 13; Takeno, 2005). Additional analysis and interpretation would be needed to determine all the geochemical reactions in these wells caused by the addition of oxygenated water, the length of time for deployment, and even the redevelopment of the wells, which occurred in the fall of 2018.

Another factor that could contribute to differences in trace element concentrations between the passive and pumped methods that warrants consideration is pump corrosion at a site where the pump has been installed for a period of time, such as at TR-1A or CC-1A, and could be corroding. The submersible pumps used at these sites were made of grade 304 stainless steel (Bennett Sample Pumps, Inc., 2020). Stainless-steel pumps can corrode when in acidic or oxidizing 
A. Alkalinity

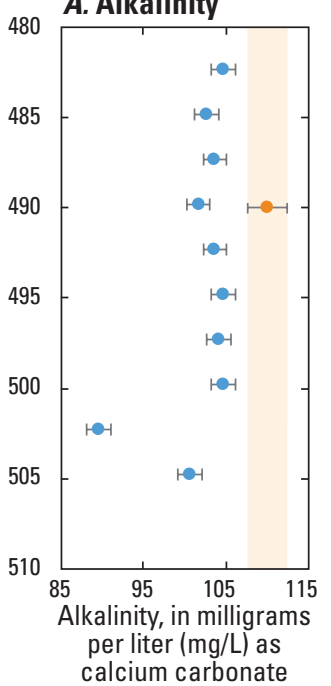

E. Chloride
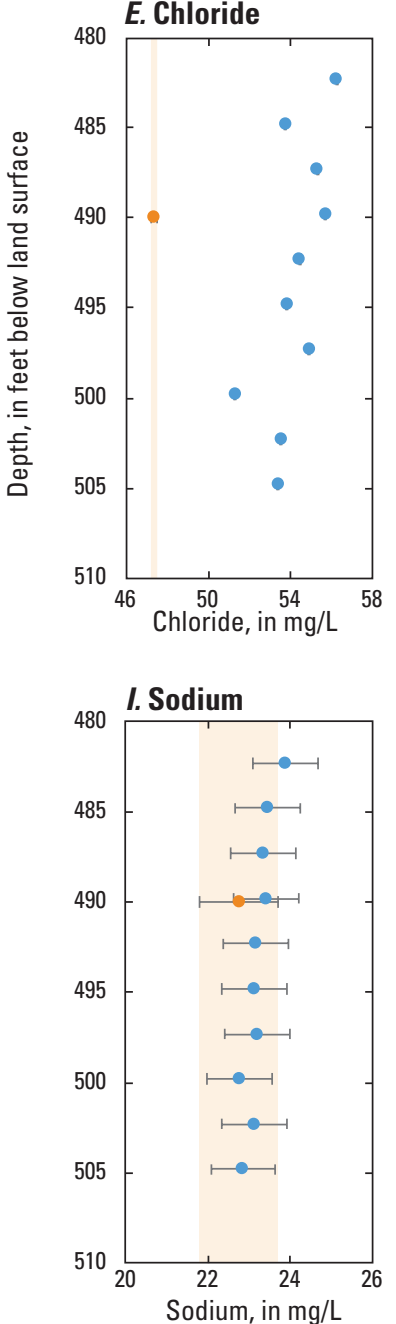

Range of uncertainty indicated by method variability of pump sampling result
B. Bicarbonate

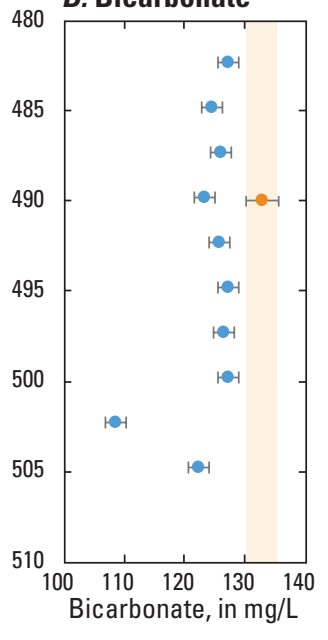

F. Fluoride
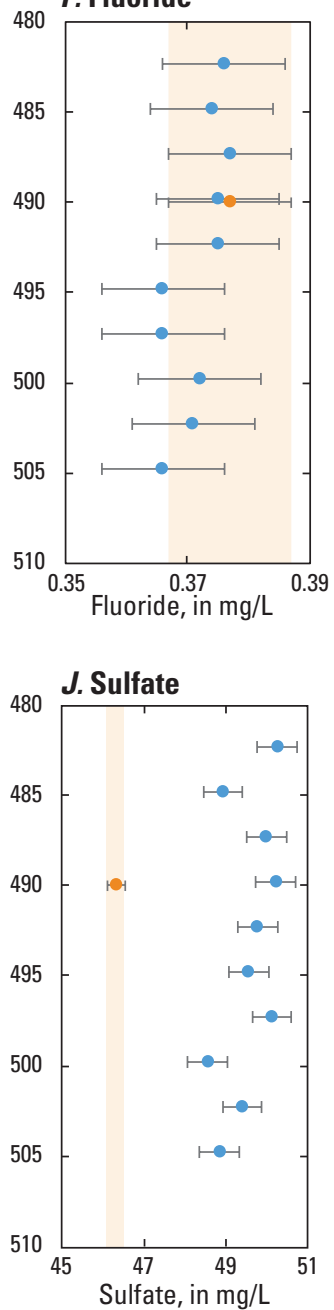

C. Bromide

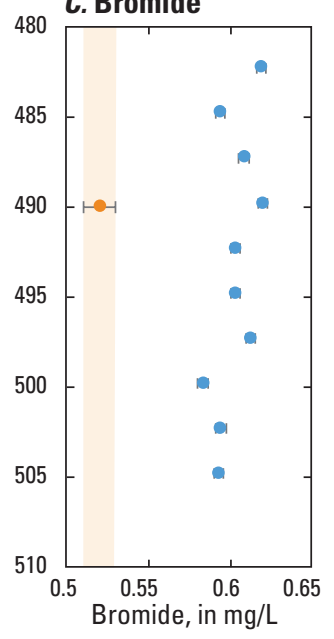

G. Magnesium

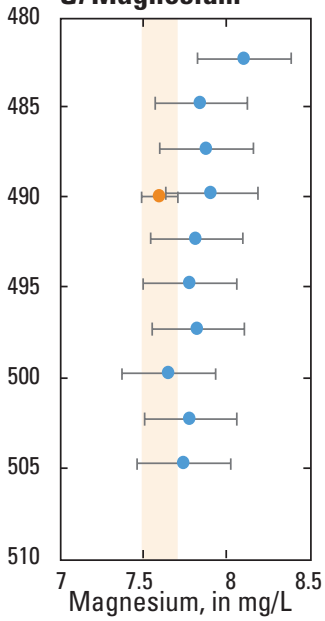

$K$. Stable isotope of
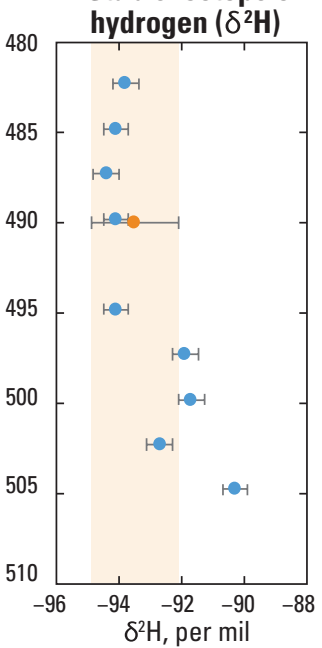

D. Calcium

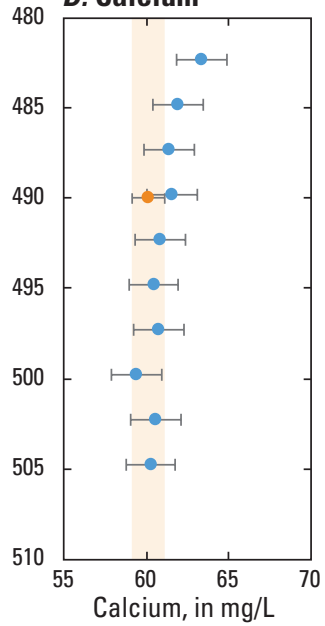

H. Potassium

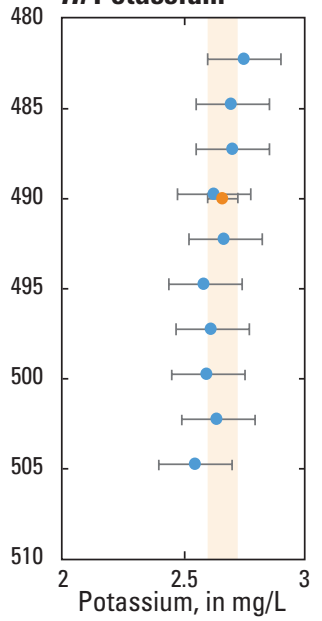

L. Stable isotope of oxygen $\left(\delta^{18} 0\right)$

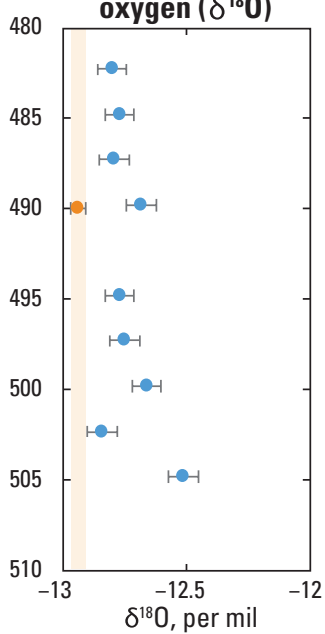

\section{EXPLANATION} Passive sampling result and method
variability - Error bar represents one standard deviation
- $\quad$ Pump sampling result and method variability-Error bar represents one standard deviation

Figure 8. Vertical profile of $A-L$, major ion and stable isotope concentrations and $M-A A$, trace element concentrations in passive and pump samples, including method variability, at CC-1A near Kirtland Air Force Base, Albuquerque, New Mexico. 

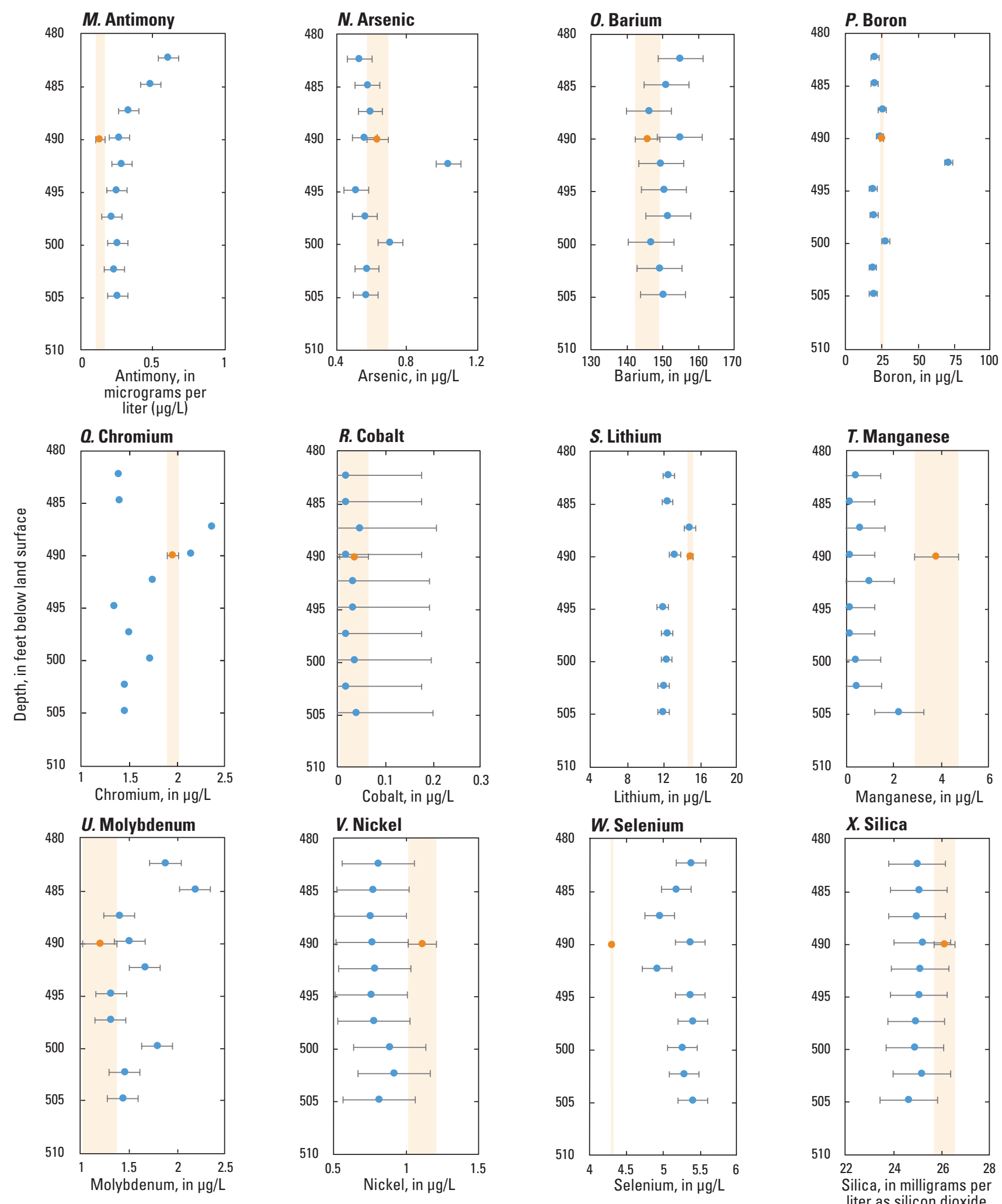

EXPLANATION Range of uncertainty indicated
by method variability of pump sampling result

$\vdash \quad$ Pump sampling result and method variability-Error bar represents one standard deviation

Figure 8. Vertical profile of $A-L$, major ion and stable isotope concentrations and $M-A A$, trace element concentrations in passive and pump samples, including method variability, at CC-1A near Kirtland Air Force Base, Albuquerque, New Mexico—Continued 

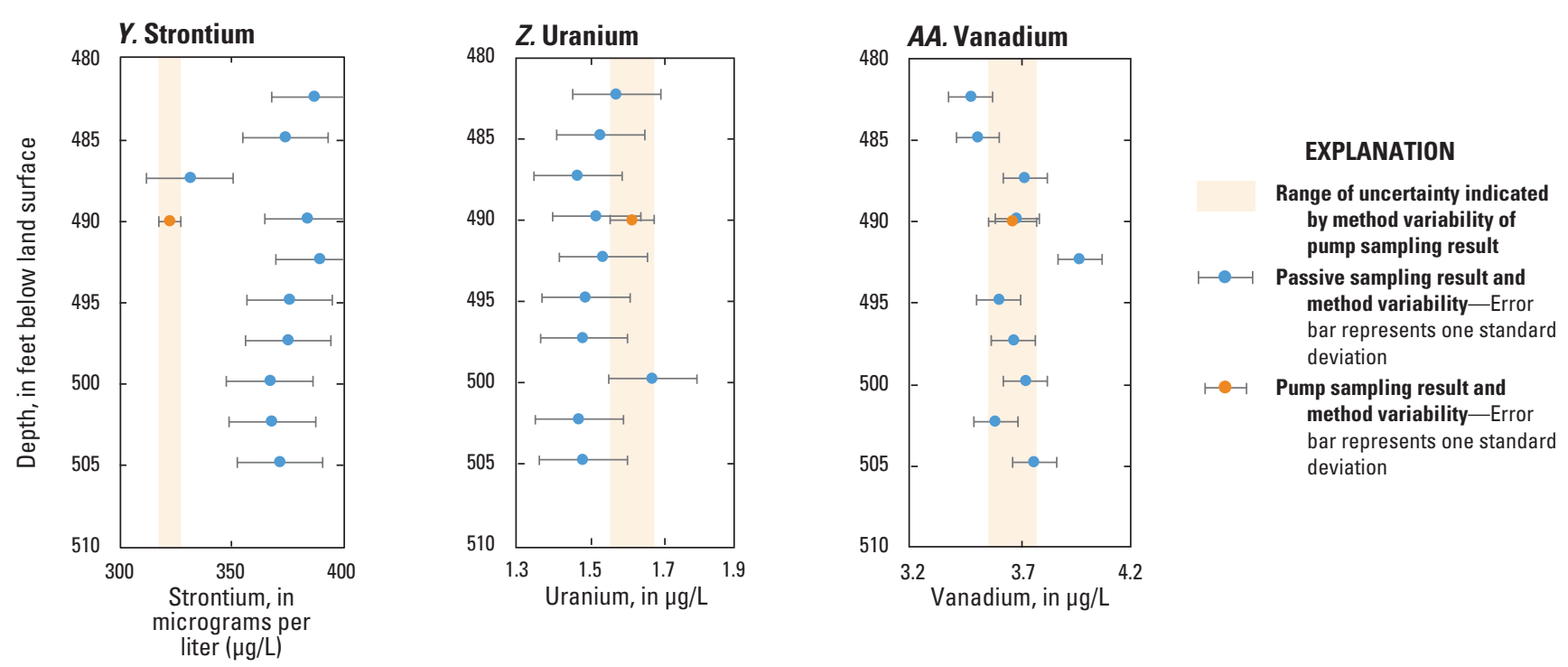

Figure 8. Vertical profile of $A-L$, major ion and stable isotope concentrations and $M-A A$, trace element concentrations in passive and pump samples, including method variability, at CC-1A near Kirtland Air Force Base, Albuquerque, New Mexico—Continued

conditions, and the common byproducts of corrosion include iron and other elements that are used to create the grade of stainless steel. Grade 304 stainless steel is composed of iron alloyed with chromium, nickel, manganese, silicon, carbon, phosphorus, and sulfur (Lapham and others, 1995). Historical quarterly sampling chemistry data from pumped sampling (fig. 14), available in the USGS National Water Information System (USGS, 2019), from TR-1A, CC-1A, and SO-1A indicates that pump corrosion is not likely the case at the study wells. (VA-1A did not have a dedicated installed pump until February 2017, and it did not stay in place for a long time.) At TR-1A, nickel concentrations, however, did increase during pump method sampling from $3.3 \mu \mathrm{g} / \mathrm{L}$ in 2015 to $8.6 \mu \mathrm{g} / \mathrm{L}$ in 2017. Nickel concentrations also increased at CC-1A, from $0.9 \mu \mathrm{g} / \mathrm{L}$ in 2015 to $7.2 \mu \mathrm{g} / \mathrm{L}$ at the end of 2016 .

\section{Determination of Optimal Sampling Depth}

After the evaluation of the RPD and method variabilities, the next step was to determine the depth at which the quarterly monitoring samplers would be best placed in the well, which for the purposes of this study is the depth where the passive sampler produces the most representative water chemistry as compared to the pumped sample data. These determinations were compared to available well log data, such as lithologic logs available from Bell and others (2018) and borehole geophysical data available through the USGS GeoLog Locator (USGS, 2020). Geophysical logs, including induction resistivity, spontaneous potential, and gamma logs, can all be indicative of lithology (Keys, 1990). Induction resistivity logs measure electrical resistivity of the borehole environment and surrounding rocks and water. Spontaneous potential logs measure potentials or voltages that develop at the contacts between shale or clay beds and a sand aquifer, and gamma logs record the amount of natural gamma radiation emitted by the rocks surrounding the borehole (Keys, 1990). For the purpose of this report, the gamma log data were graphed using 1-ft averages of the available data to create a smoother line. The ideal criteria for quarterly monitoring sampler placement would be an interval with, if possible, known passive samplers that have low RPD and sand or other highly transmissive zones.

At CC-1A, the inorganic quarterly samples have been collected at $498.5 \mathrm{ft}$ bls (fig. 15), and the VOC sampler has been located at $496.0 \mathrm{ft}$ bls. For this study, sampler $7(498.1 \mathrm{ft}$ bls) had the most analytes within the established RPD criteria, and sampler $8(500.6 \mathrm{ft}$ bls) had the most analytes with the lowest RPD (table 5). The lithologic log (Bell and others, 2018) indicates that the screened interval is sand and gravel toward the top and clay in the rest of the interval; however, the geophysical data indicate that the lithology could be slightly different in this screened interval than what is indicated in the lithologic log. Samplers 7 and 8 from this study correspond to areas in the well with slightly higher resistivity and spontaneous potential and lower gamma, which all indicate a higher conductivity and less clay. The quarterly samplers could stay where they currently located, since the initial deployment in 2017, and likely collect a representative sample from the aquifer. 
A. Alkalinity

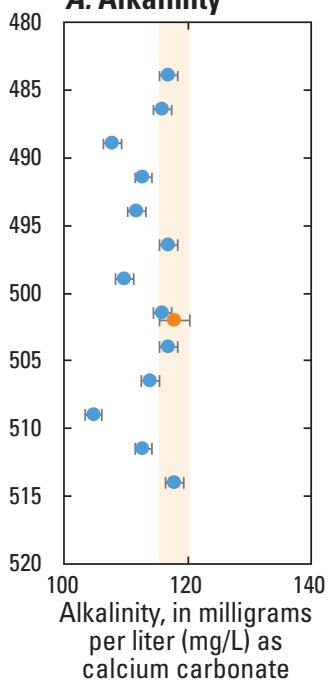

E. Chloride
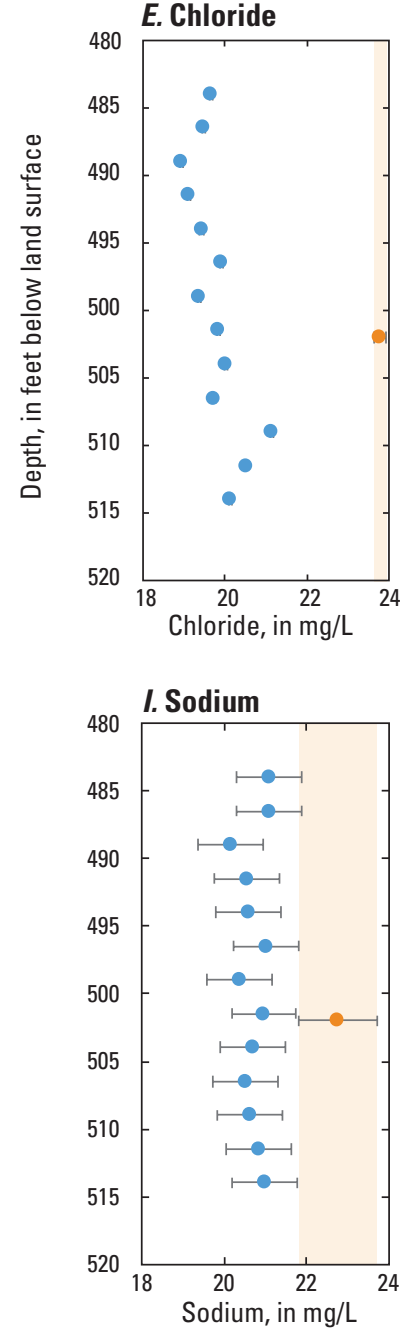

B. Bicarbonate

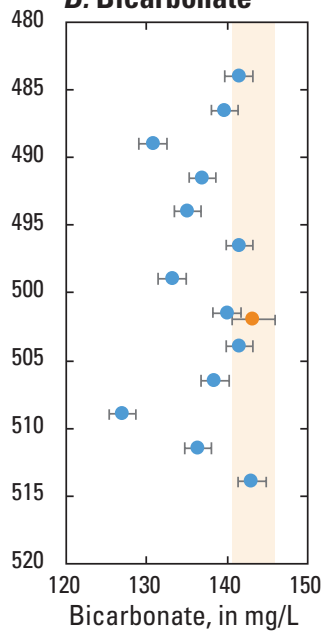

F. Fluoride
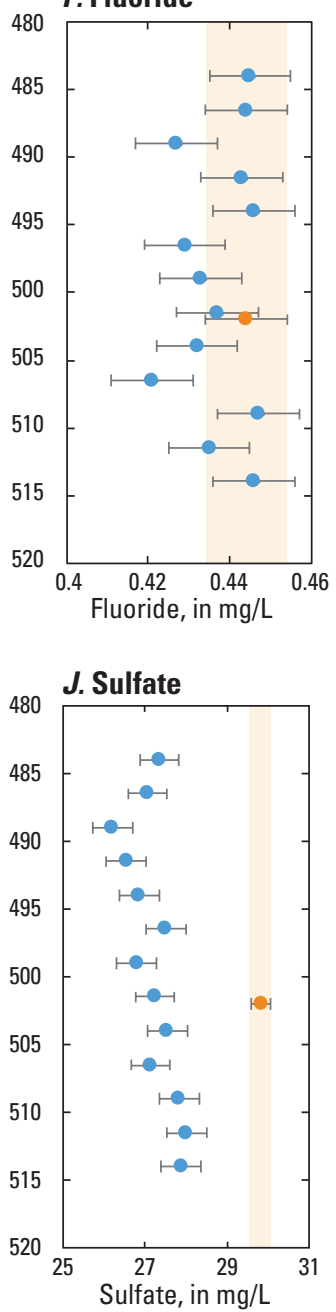

C. Bromide

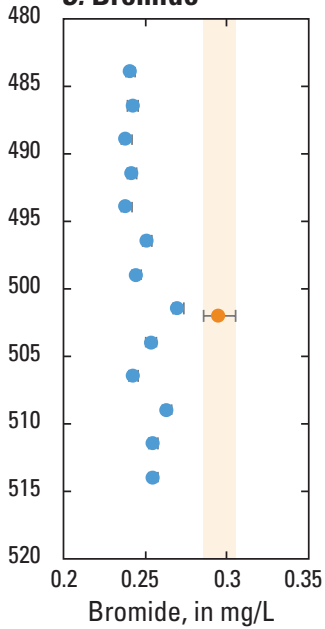

G. Magnesium

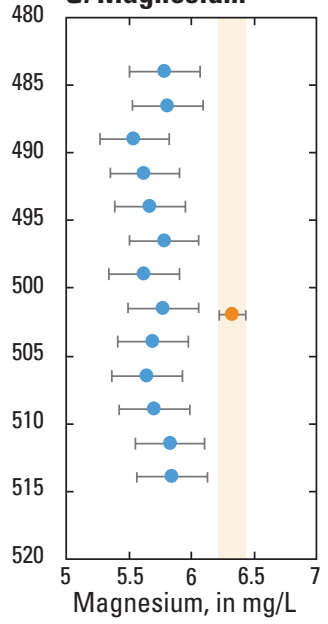

$K$. Stable isotope of hydrogen $\left(\delta^{2} \mathrm{H}\right)$

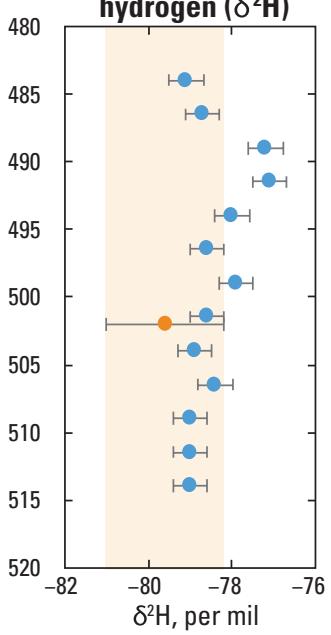

D. Calcium

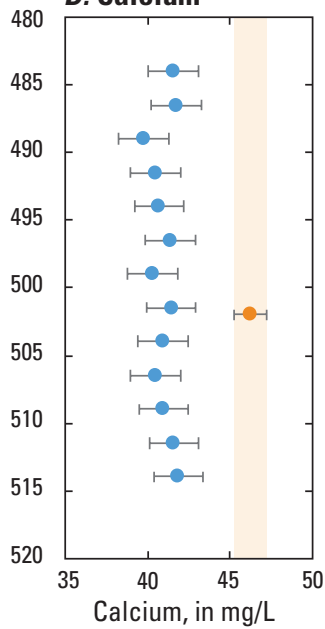

H. Potassium

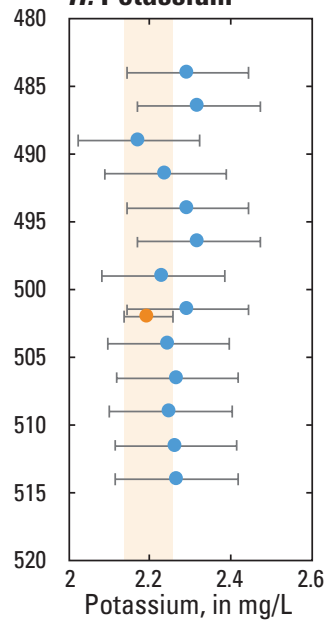

L. Stable isotope of oxygen $\left(\delta^{18} 0\right)$

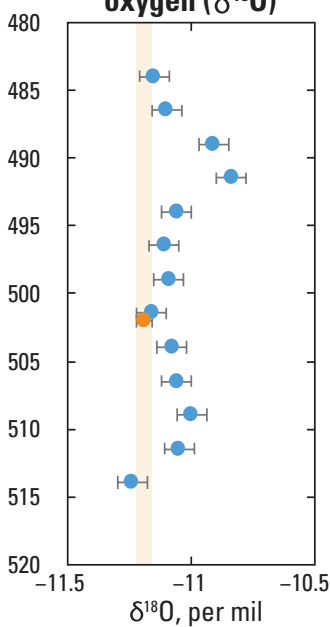

Range of uncertainty indicated by method variability of pump sampling result

\section{EXPLANATION}

Passive sampling result and method
variability_Error bar represents one standard deviation
Pump sampling result and method variability - Error bar represents one standard deviation

Figure 9. Vertical profile of $A-L$, major ion and stable isotope concentrations and $M-C C$, trace element concentrations in passive and pump samples, including method variability, at SO-1A. 

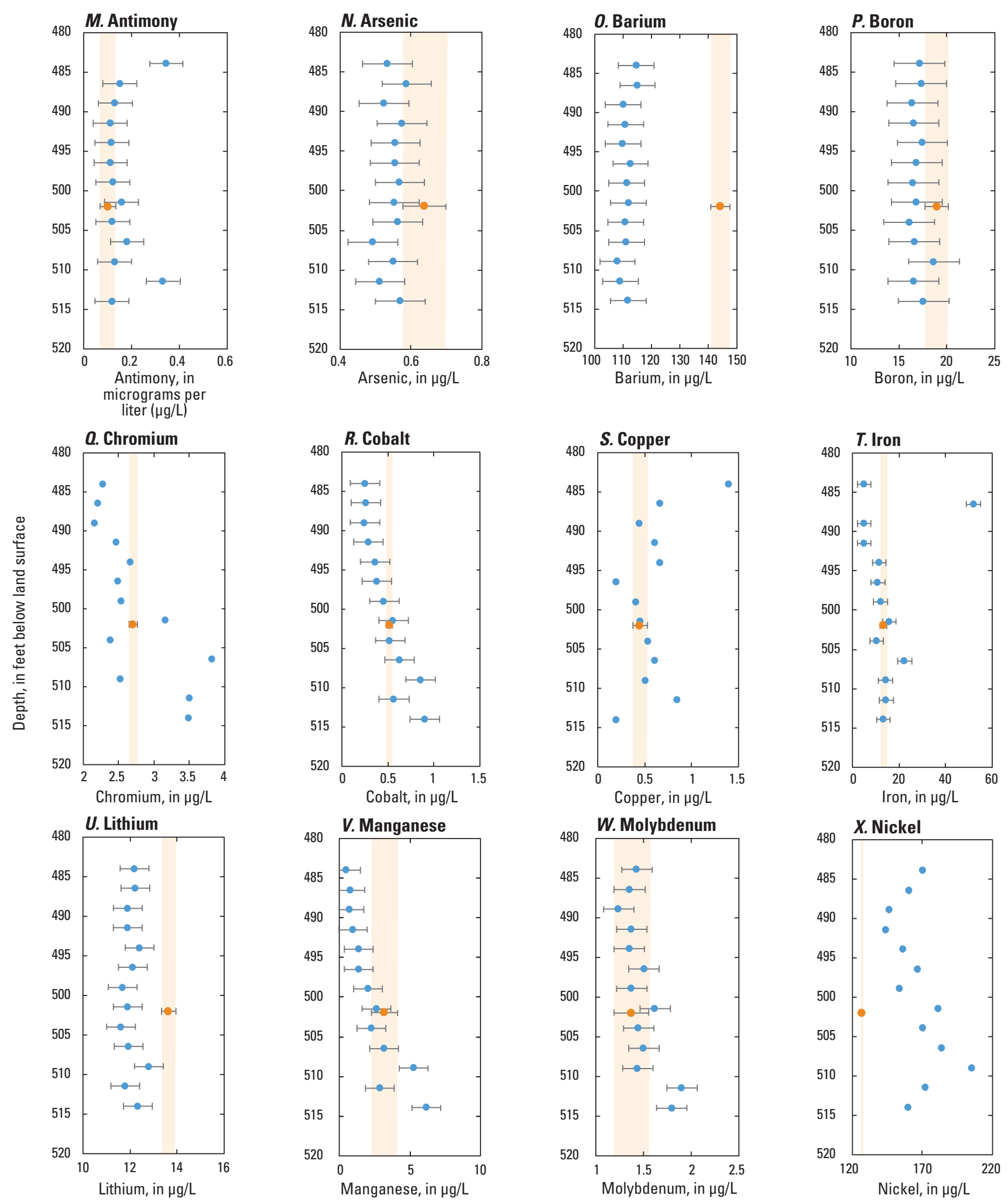
Range of uncertainty indicated
by method variability of

EXPLANATION pump sampling result

$\vdash \quad$ Pump sampling result and method variability-Error bar represents one standard deviation

Figure 9. Vertical profile of $A-L$, major ion and stable isotope concentrations and $M-C C$, trace element concentrations in passive and pump samples, including method variability, at S0-1A.-Continued 


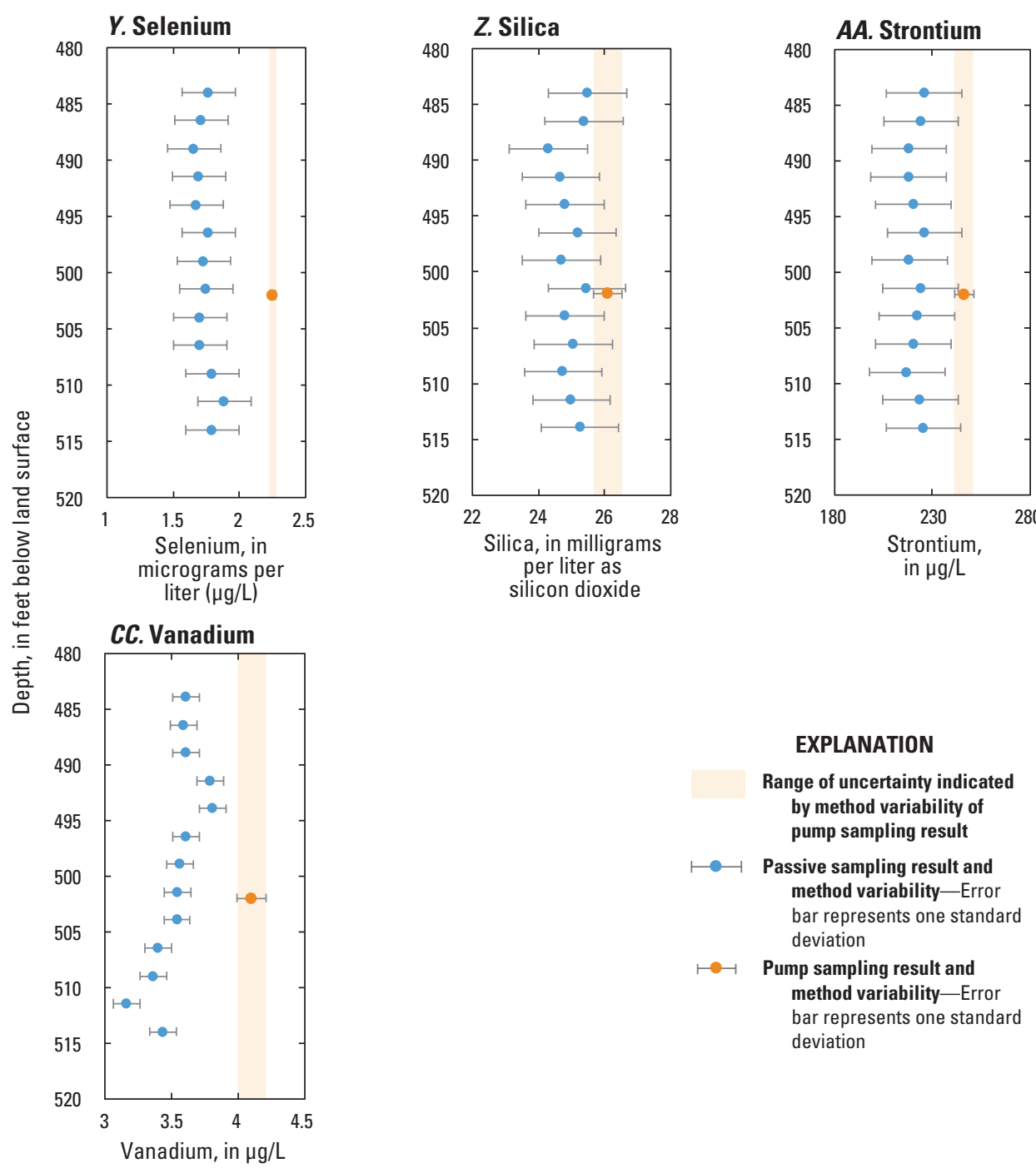

Figure 9. Vertical profile of $A-L$, major ion and stable isotope concentrations and $M-C C$, trace element concentrations in passive and pump samples, including method variability, at SO-1A.-Continued 

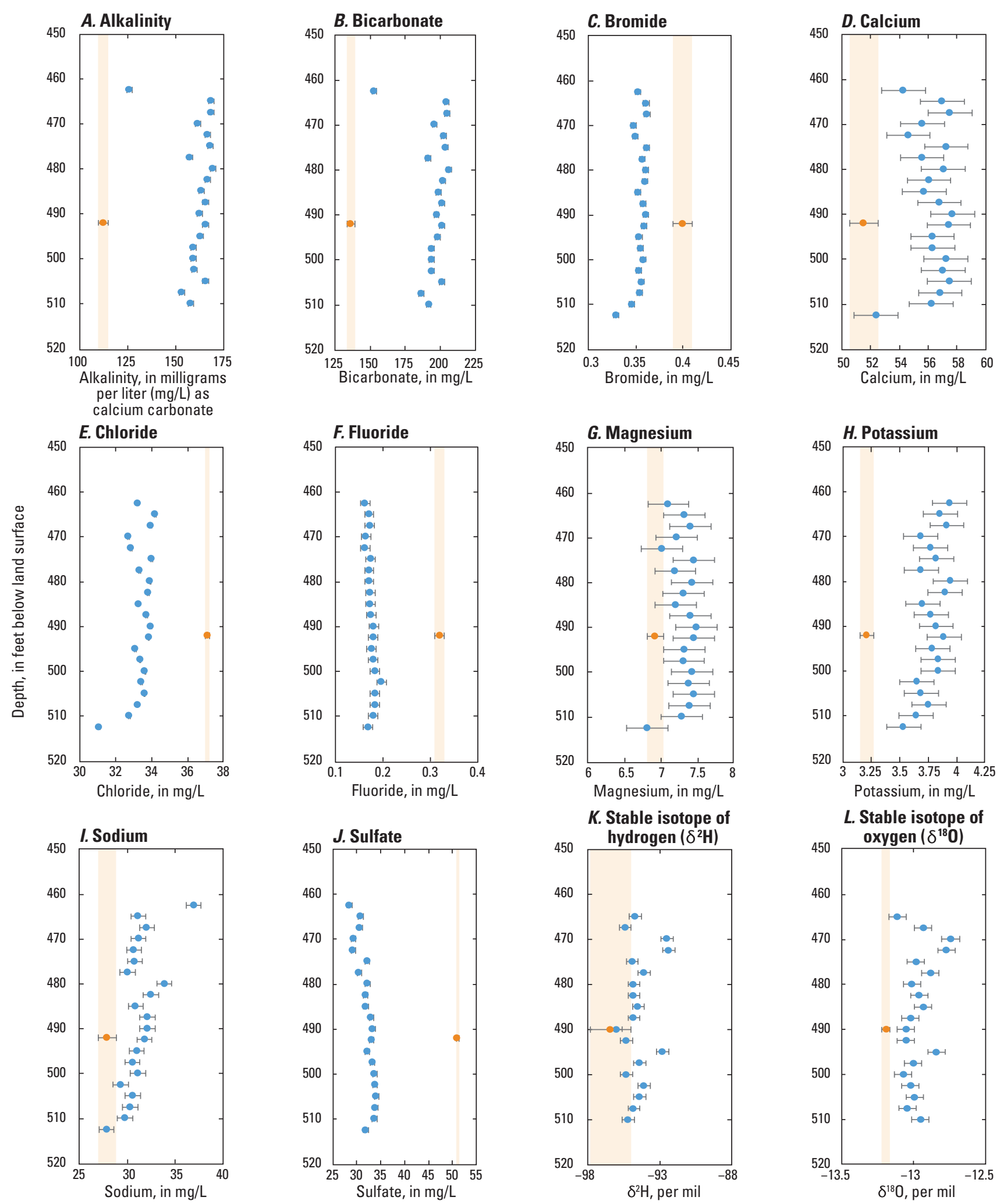

Range of uncertainty indicated
by method variability of pump sampling result

\section{EXPLANATION}

Passive sampling result and method
variability —Error bar represents one standard deviation
Pump sampling result and method variability-Error bar represents one standard deviation

Figure 10. Vertical profile of $A-L$, major ion and stable isotope concentrations and $M-X$, trace element concentrations in passive and pump samples, including method variability, at TR-1A. 
M. Antimony

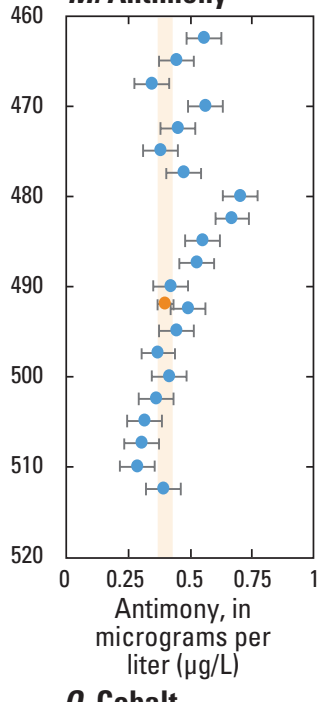

Q. Cobalt

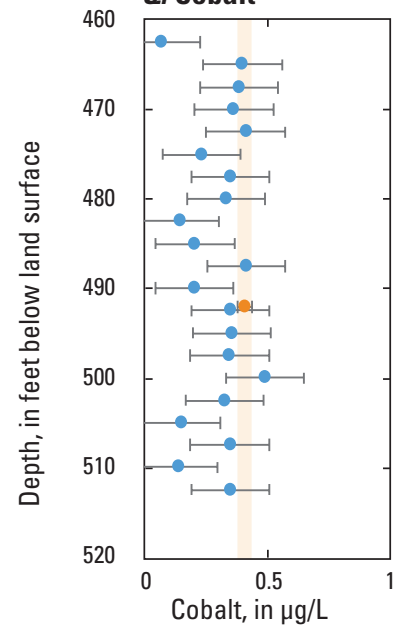

U. Molybdenum

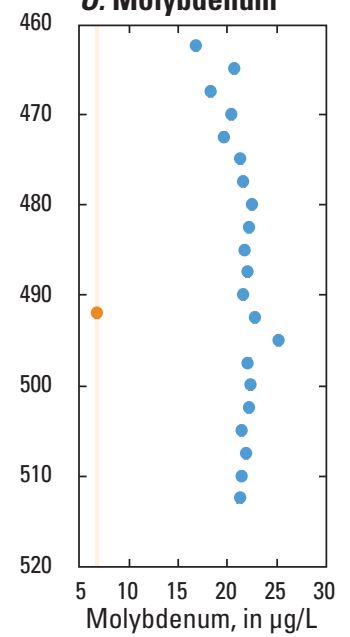

N. Arsenic

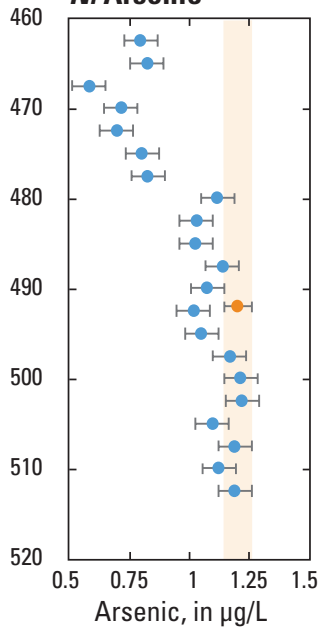

R. Iron

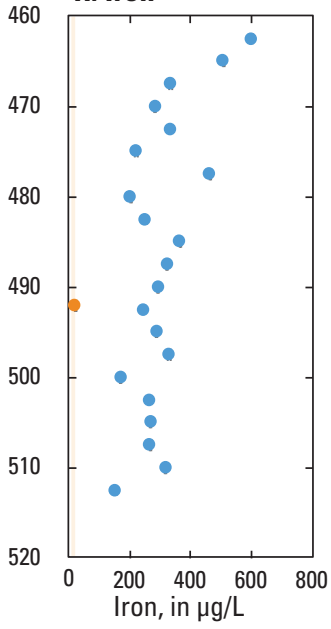

V. Strontium

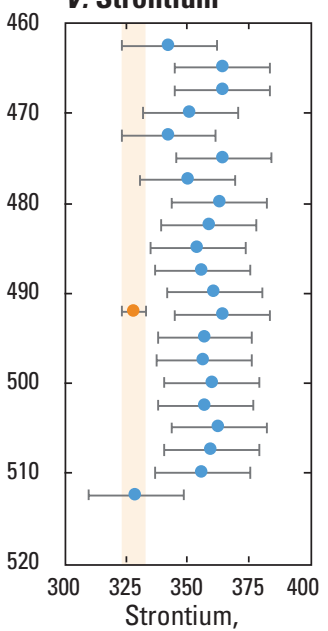

O. Barium

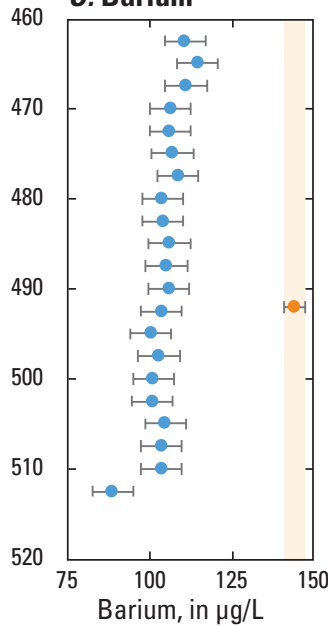

S. Lithium
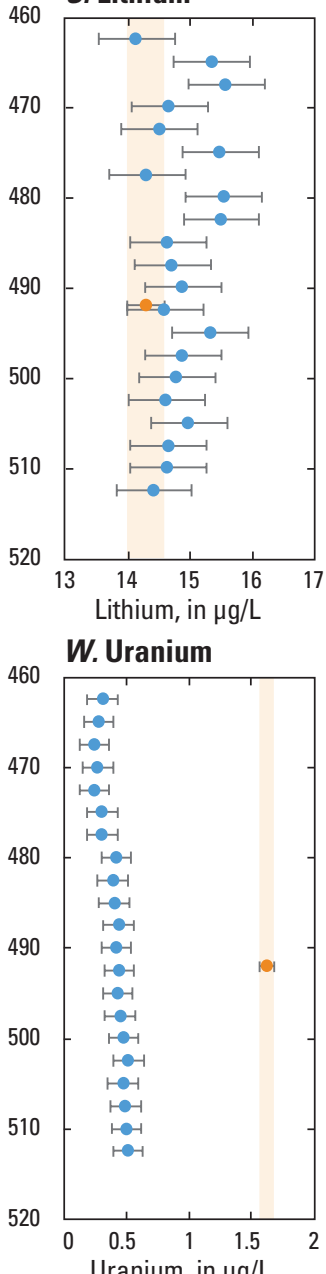

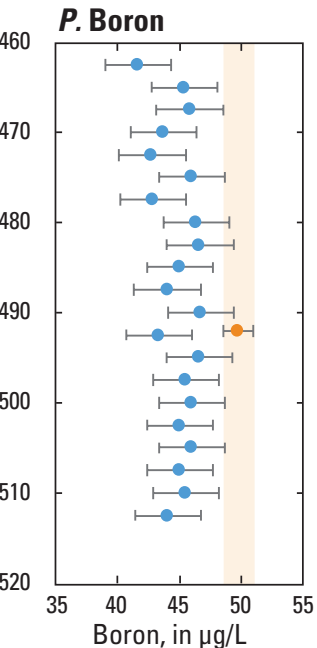

T. Manganese

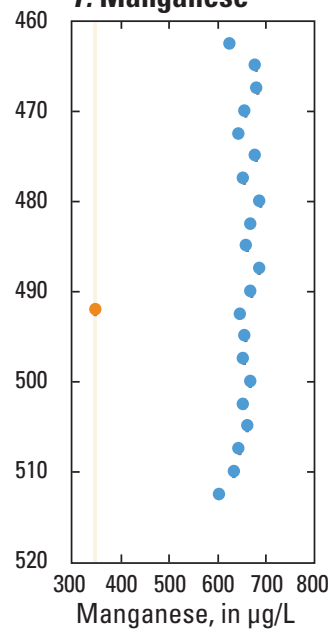

$X$. Vanadium

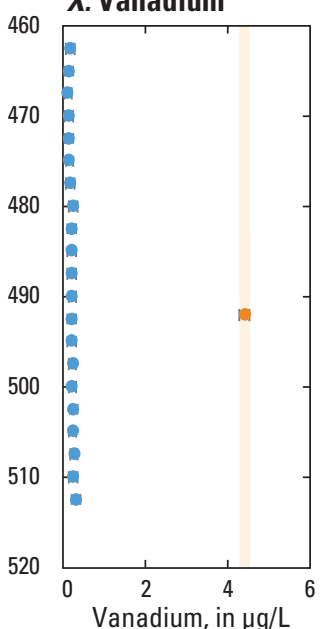

Range of uncertainty indicated by method variability of pump sampling result in $\mu \mathrm{g} / \mathrm{L}$

\section{EXPLANATION}

Passive sampling result and method
variability - Error bar represents one standard deviation

Pump sampling result and method variability-Error bar represents one standard deviation

Figure 10. Vertical profile of $A-L$, major ion and stable isotope concentrations and $M-X$, trace element concentrations in passive and pump samples, including method variability, at TR-1A.-Continued 


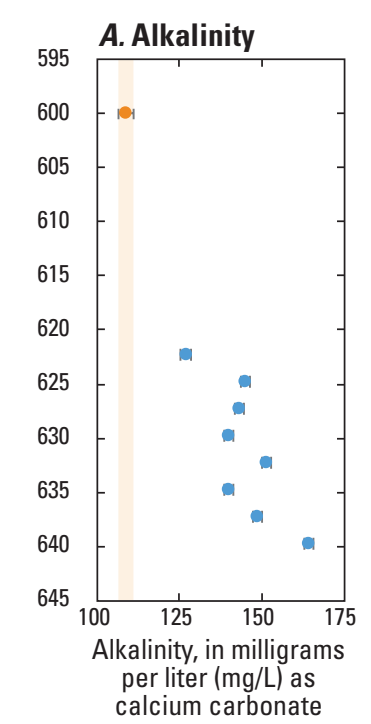

\section{B. Bicarbonate}

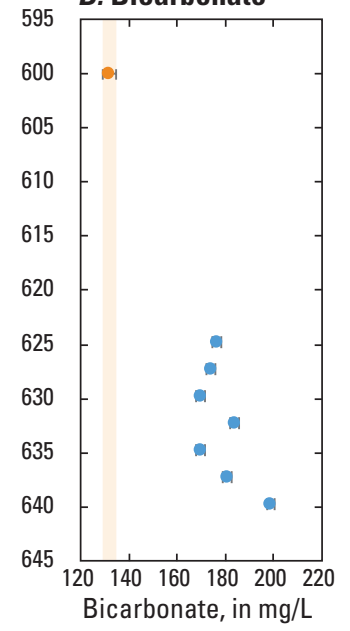

E. Chloride
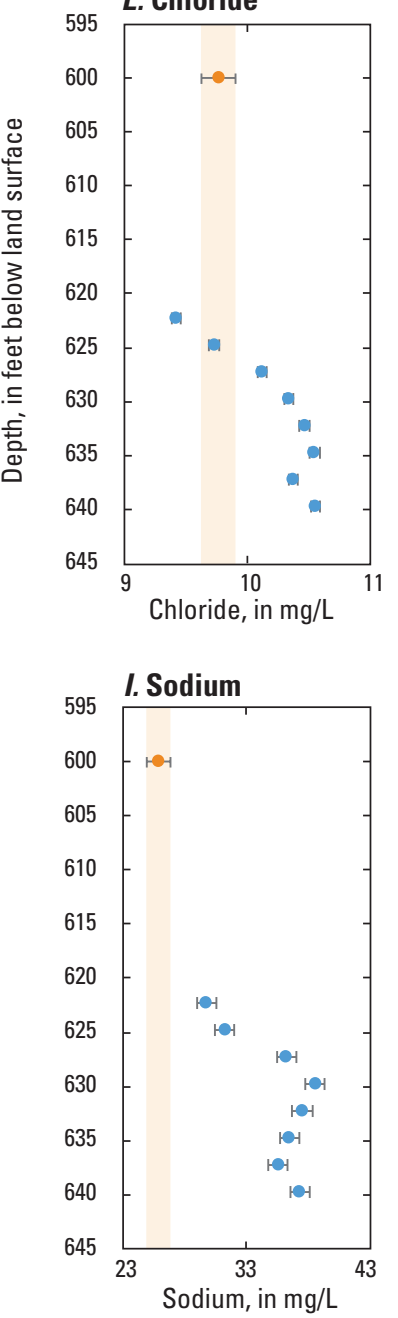

Range of uncertainty indicated by method variability of pump sampling result
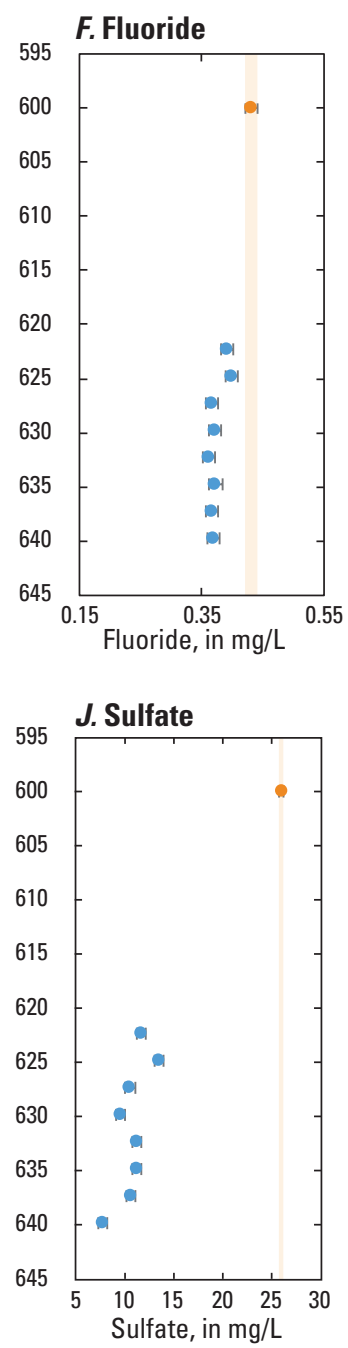

C. Bromide

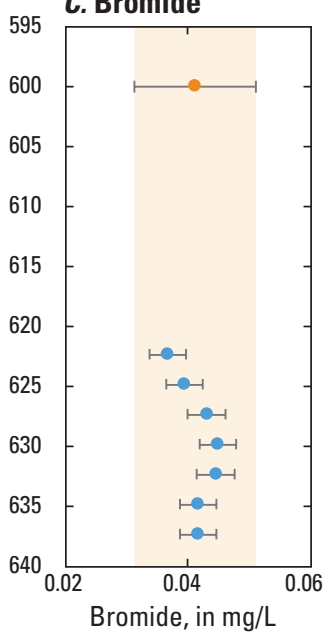

G. Magnesium

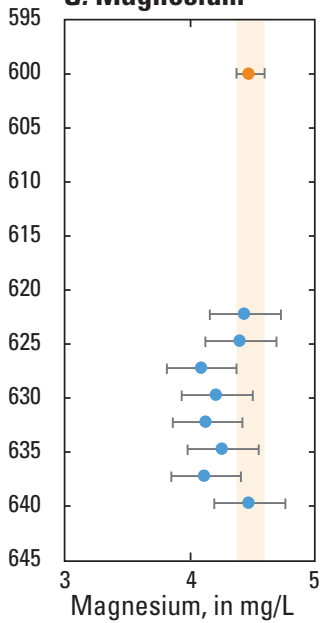

$K$. Stable isotope of 595 hydrogen $\left(\delta^{2} H\right)$

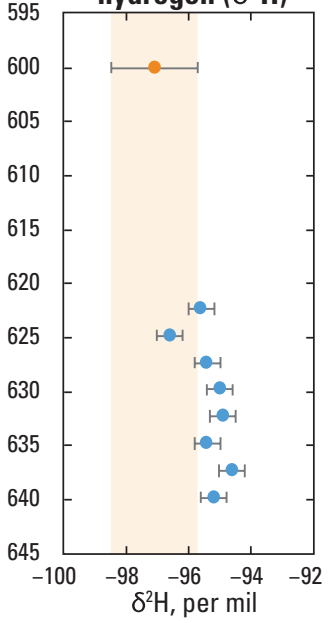

D. Calcium

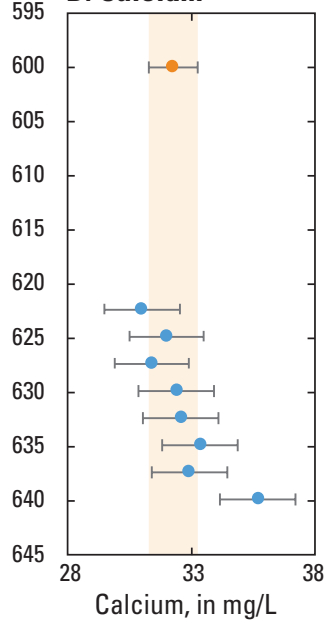

H. Potassium

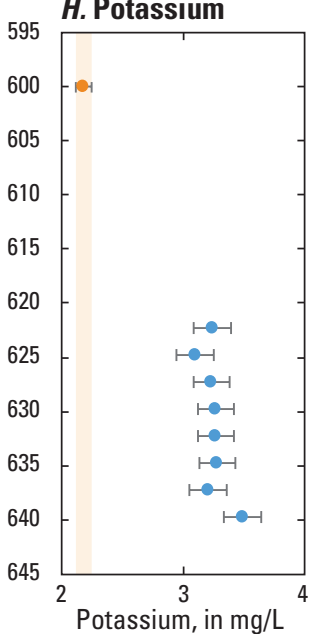

L. Stable isotope of

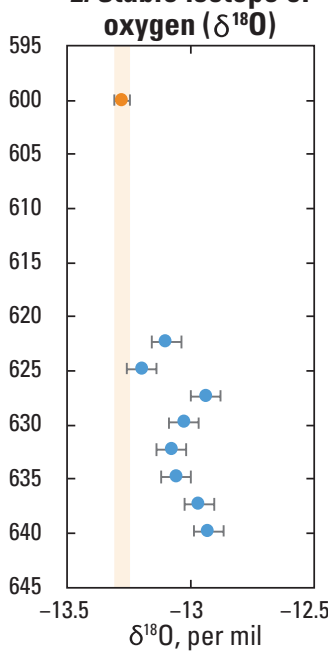
EXPLANATION

Passive sampling result and method
variability - Error bar represents one standard deviation
Pump sampling result and method variability-Error bar represents one standard deviation

Figure 11. Vertical profile of $A-L$, major ion and stable isotope concentrations and $M-Z$, trace element concentrations in passive and pump samples, including method variability, at VA-1A. 
M. Antimony

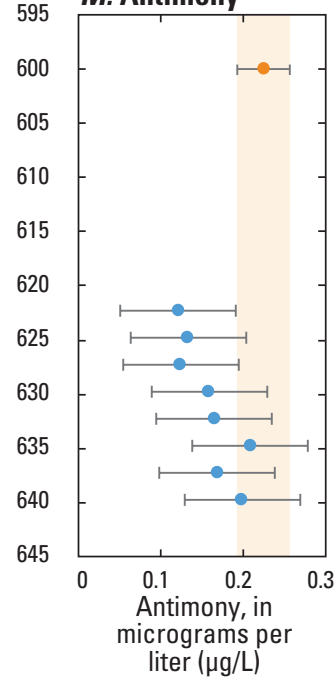

Q. Cobalt
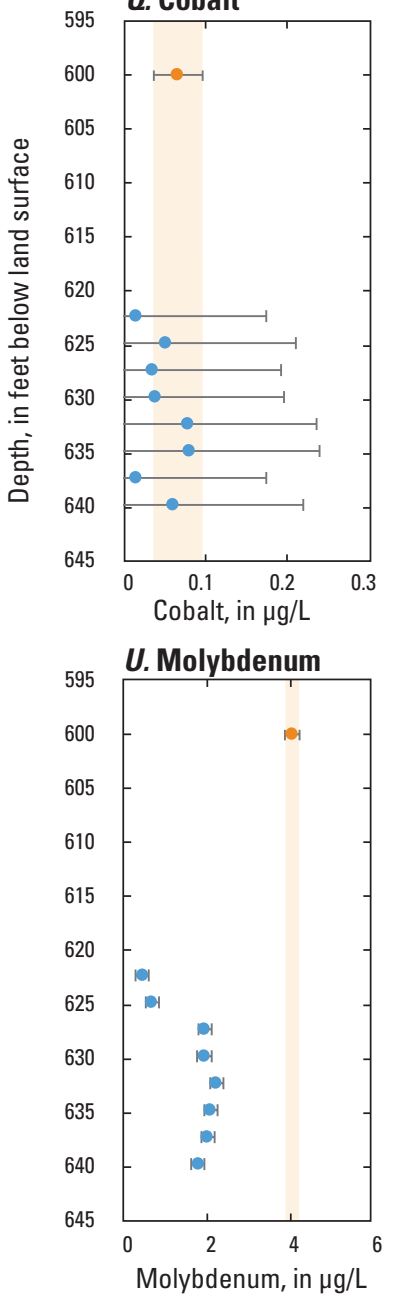

N. Arsenic

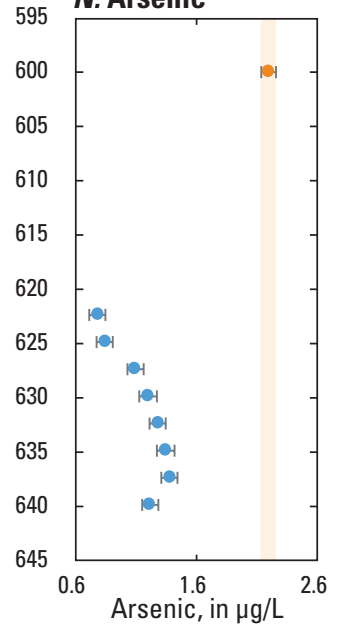

R. Iron
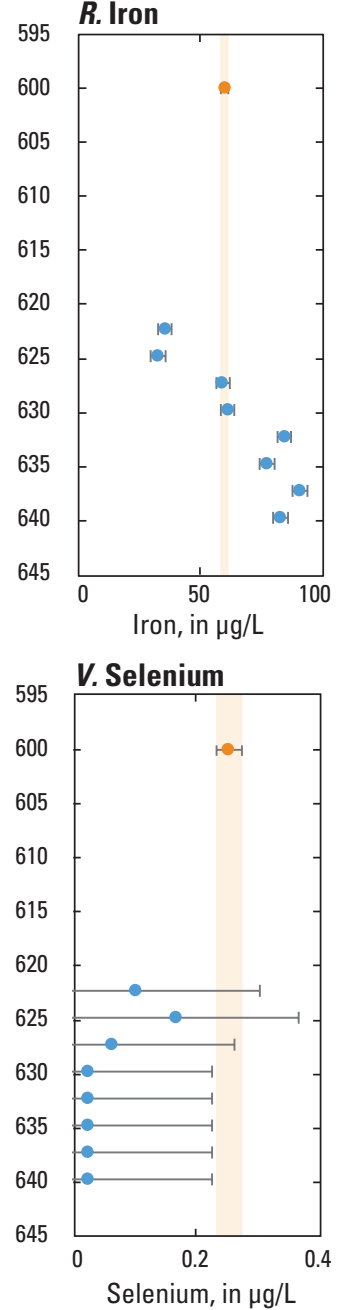

0. Barium

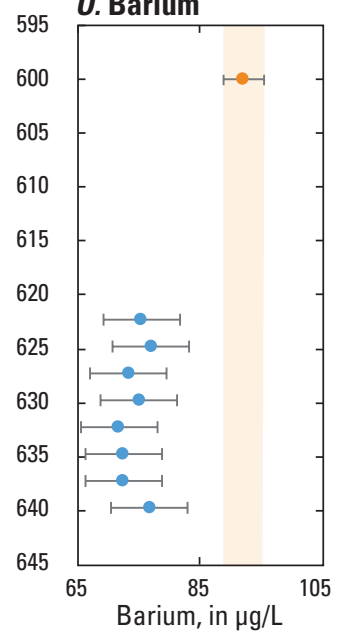

S. Lithium

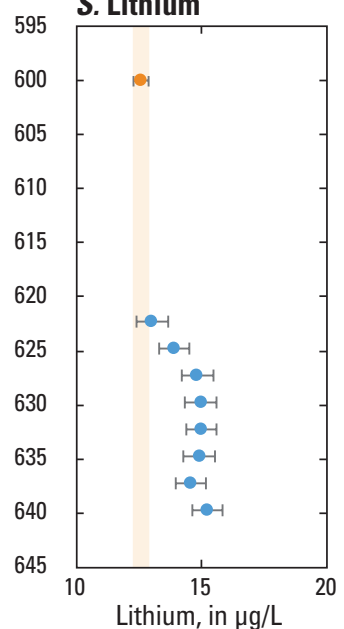

W. Silica

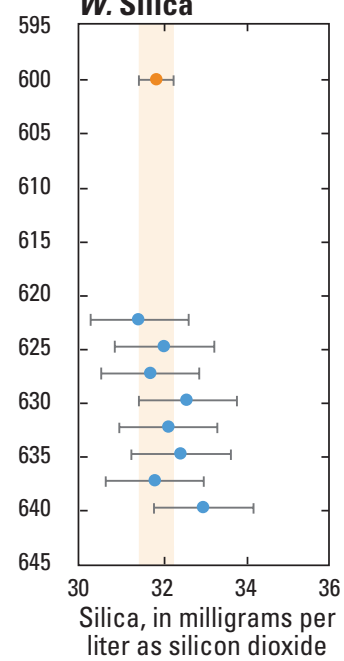

EXPLANATION

Range of uncertainty indicated by method variability of pump sampling result

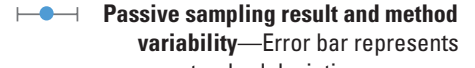
one standard deviation

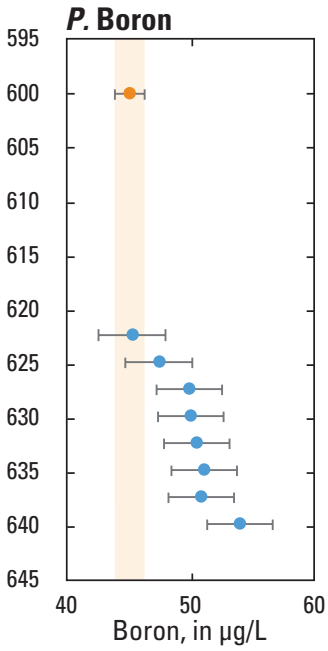

T. Manganese
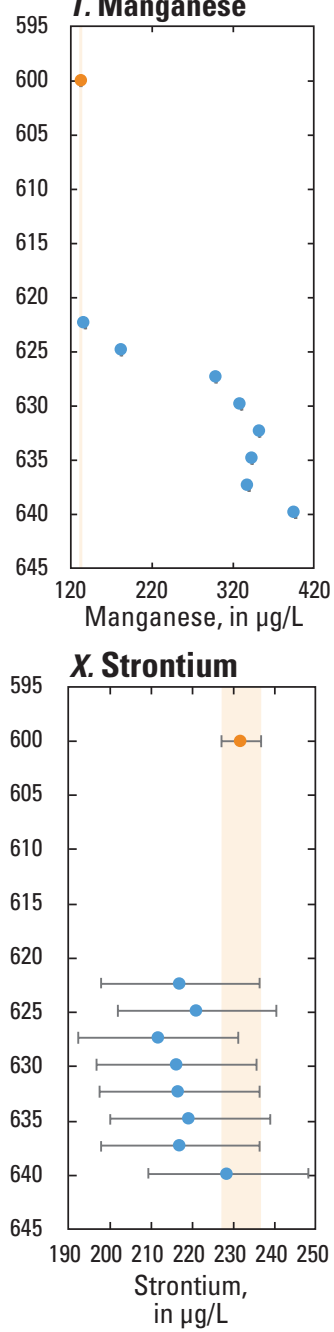

Figure 11. Vertical profile of $A-L$, major ion and stable isotope concentrations and $M-Z$, trace element concentrations in passive and pump samples, including method variability, at VA-1A. - Continued 

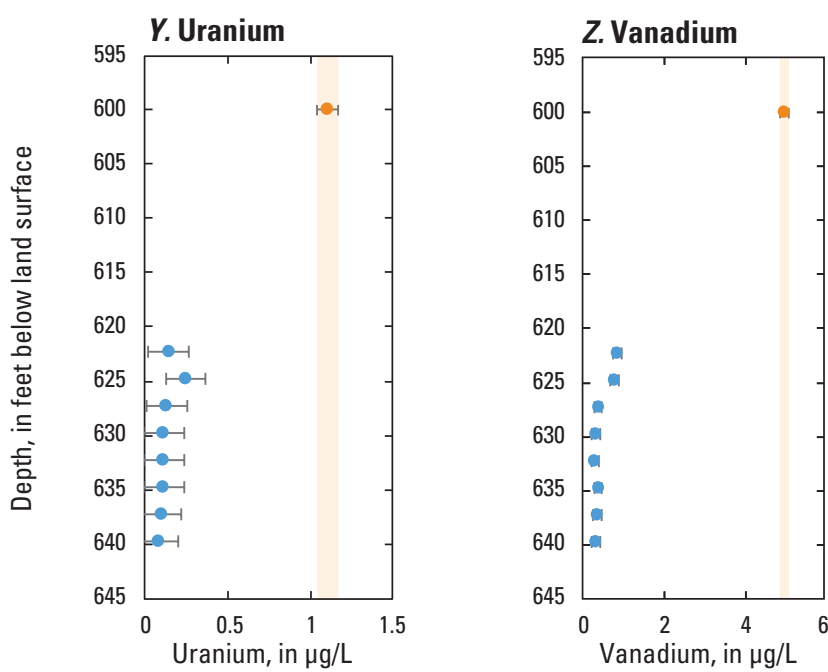

\section{EXPLANATION}

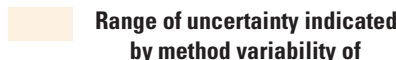
by method variability of pump sampling result

$\longmapsto \quad$ Passive sampling result and method variability-Error bar represents one standard deviation

$\vdash$ Pump sampling result and method variability-Error bar represents one standard deviation

Figure 11. Vertical profile of $A-L$, major ion and stable isotope concentrations and $M-Z$, trace element concentrations in passive and pump samples, including method variability, at VA-1A.-Continued

The screened interval for SO-1A consists entirely of sand and gravel with clay (fig. 16). The quarterly organic sample has been collected at $506.0 \mathrm{ft}$ bls. For this study, samplers 7 (499.0 ft bls) and 11 (509.0 ft bls) had the most analytes within the established RPD criteria, and sampler $13(514.0 \mathrm{ft}$ bls) had the most analytes with the lowest RPD (table 6). The resistivity and spontaneous potential are fairly consistent throughout the screened interval. The gamma log decreases slightly in the areas of samplers 7 and 11. The quarterly samplers may be more representative if they are moved up higher toward sampler 7, but the current location, since initial deployment in 2017, is likely just as representative given that the majority of the samplers at SO-1A are within the RPD for most analytes (table 6).

At TR-1A, quarterly sampling events have been located at $486.5 \mathrm{ft}$ bls, with the organic sampler located at $484.0 \mathrm{ft}$ bls. Due to redox processes in this well, it is difficult to assess where the samplers would be best placed. Samplers that had the most analyte concentrations within RPD criteria are scattered throughout the sampling interval (fig. 17, table 7). Samplers with the highest RPDs are located near the water table and at the bottom of the screened interval. At TR-1A, the resistivity decreases through the profiled portion of the screened interval. However, this decrease is likely due to interference from the water table, which at the time of logging on April 13, 2013, was at approximately $480.0 \mathrm{ft}$ bls. Taking the historical water level into consideration, the resistivity increases below $500.0 \mathrm{ft}$ bls. The spontaneous potential is relatively consistent throughout the screened interval, and the gamma log data indicate that some intervals may have slightly more clay than sand and that the bottom sampler may be in a sandier interval. The lithologic log consists entirely of sand (fig. 17). Sampler 2 is located less than $10 \mathrm{ft}$ below the water table. Water table levels could fluctuate in this well, thus putting sampler 2 at a risk of being above the groundwater. Samplers could be placed at $504.0 \mathrm{ft}$ bls near samplers 17 (503.2 ft bls) and 18 (508.2 ft bls) because of the RPD criteria and because this location has the lowest resistivity. The use of deoxygenated water in the passive samplers is also recommended (Imbrigiotta and Harte, 2020).

VA-1A is the only sentinel well in this study with a screened interval that is entirely submerged below the water table, with a dedicated pump that extends to only about $600.0 \mathrm{ft}$ bls. The quarterly monitoring has been located at $623.5 \mathrm{ft}$ bls (fig. 18). The screened interval at VA-1A is sand and clay and is located from 620.0 to $640.0 \mathrm{ft}$ bls. The sampler with the most analytes within the RPD criteria was sampler 6 (633.5 ft bls), and sampler 2 had the most analytes with the lowest RPD (table 8). Of note, the passive sample results are likely influenced by redox processes at this well. Resistivity and spontaneous potential remained consistent throughout the interval but decreased slightly between 623.0 and $627.0 \mathrm{ft}$ bls (fig. 18), which corresponds to the location of sampler 2. These findings indicate the current position, since the initial deployment in 2017) of sampling is likely representative of pumped samples. Because of the likely influence by redox processes, deoxygenated water is recommended to be used in the passive sampler (Imbrigiotta and Harte, 2020). 
Table 9. Redox process assignments of pump sampling results at sentinel wells at and near Kirtland Air Force Base, Albuquerque, New Mexico, April 2019.

[mg/L, milligrams per liter; $\mu \mathrm{g} / \mathrm{L}$, micrograms per liter; *, value was below laboratory detection limit, but was used in the redox process calculation (McMahon and Chapelle, 2008; Jurgens and others, 2009)]

\begin{tabular}{|c|c|c|c|c|c|c|c|c|c|}
\hline \multirow{2}{*}{$\begin{array}{l}\text { USGS site } \\
\text { identification number } \\
\text { (USGS, 2019) }\end{array}$} & \multirow[b]{2}{*}{$\begin{array}{l}\text { Well short } \\
\text { name }\end{array}$} & \multirow{2}{*}{$\begin{array}{c}\text { Sample } \\
\text { collection date }\end{array}$} & \multicolumn{5}{|c|}{ Redox variables } & \multirow{2}{*}{$\begin{array}{l}\text { General redox } \\
\text { category }\end{array}$} & \multirow[b]{2}{*}{ Redox process } \\
\hline & & & $\begin{array}{c}\text { Dissolved } \\
\text { oxygen, mg/L }\end{array}$ & $\begin{array}{c}\text { Nitrate, as } \\
\text { nitrogen, } \mathrm{mg} / \mathrm{L}\end{array}$ & $\begin{array}{c}\text { Manganese, } \\
\mu \mathrm{g} / \mathrm{L}\end{array}$ & $\begin{array}{l}\text { Iron, } \\
\mu \mathrm{g} / \mathrm{L}\end{array}$ & $\begin{array}{c}\text { Sulfate, } \\
\mathrm{mg} / \mathrm{L}\end{array}$ & & \\
\hline 350359106335201 & CC-1A & April 9, 2019 & 10.1 & 1.74 & 3.79 & $10.0^{*}$ & 46.3 & Oxic & $\begin{array}{l}\text { Oxygen- } \\
\text { reducing }\end{array}$ \\
\hline 350359106333901 & $\mathrm{SO}-1 \mathrm{~A}$ & April 16, 2019 & 10.4 & 1.13 & 3.19 & 13.3 & 29.8 & Oxic & $\begin{array}{l}\text { Oxygen- } \\
\text { reducing }\end{array}$ \\
\hline 350408106335601 & TR-1A & April 11, 2019 & 3.8 & 0.80 & 347.82 & 21.6 & 51.1 & Mixed (oxic-anoxic) & $\begin{array}{l}\text { Oxygen- and } \\
\text { manganese- } \\
\text { reducing }\end{array}$ \\
\hline 350304106345401 & VA-1A & April 18, 2019 & 1.2 & $0.05^{*}$ & 132.26 & 59.9 & 26.0 & Mixed (oxic-anoxic) & $\begin{array}{l}\text { Oxygen- and } \\
\text { manganese- } \\
\text { reducing }\end{array}$ \\
\hline
\end{tabular}


$\boldsymbol{A}$

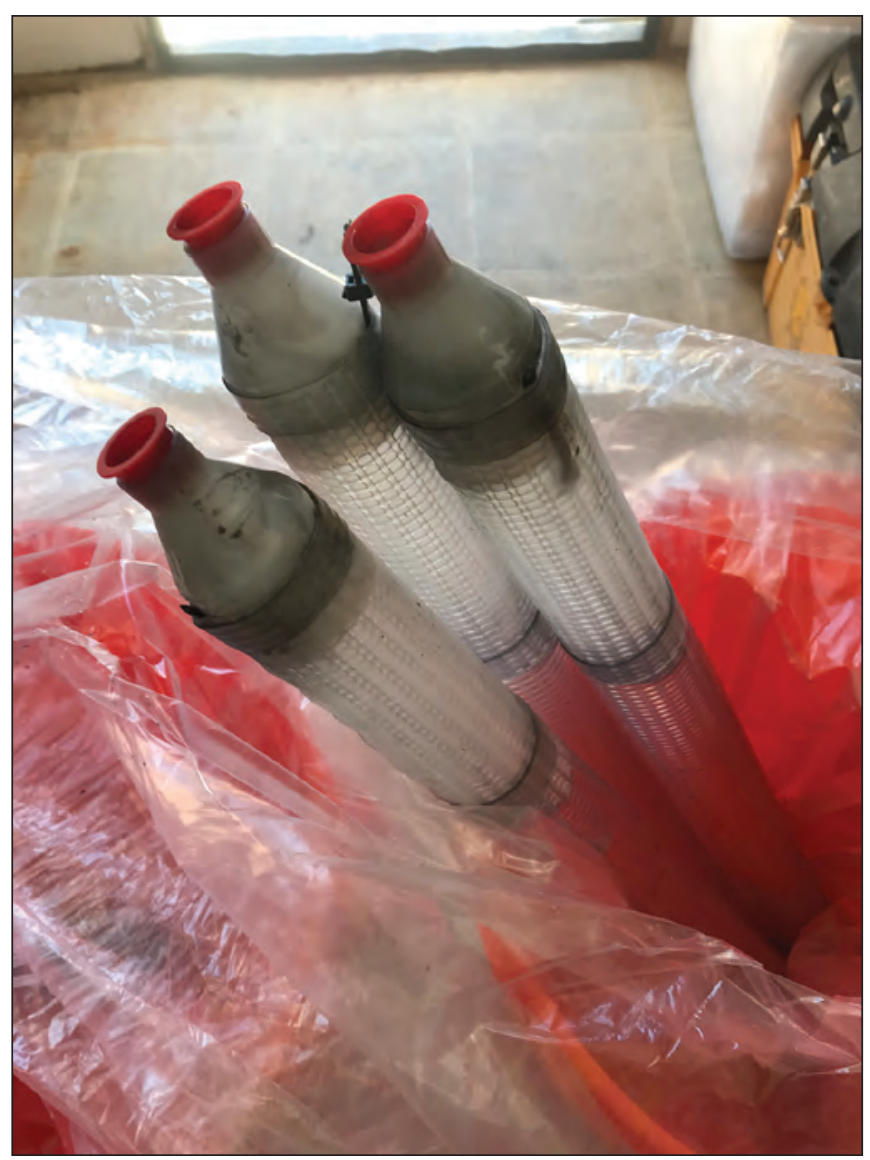

B

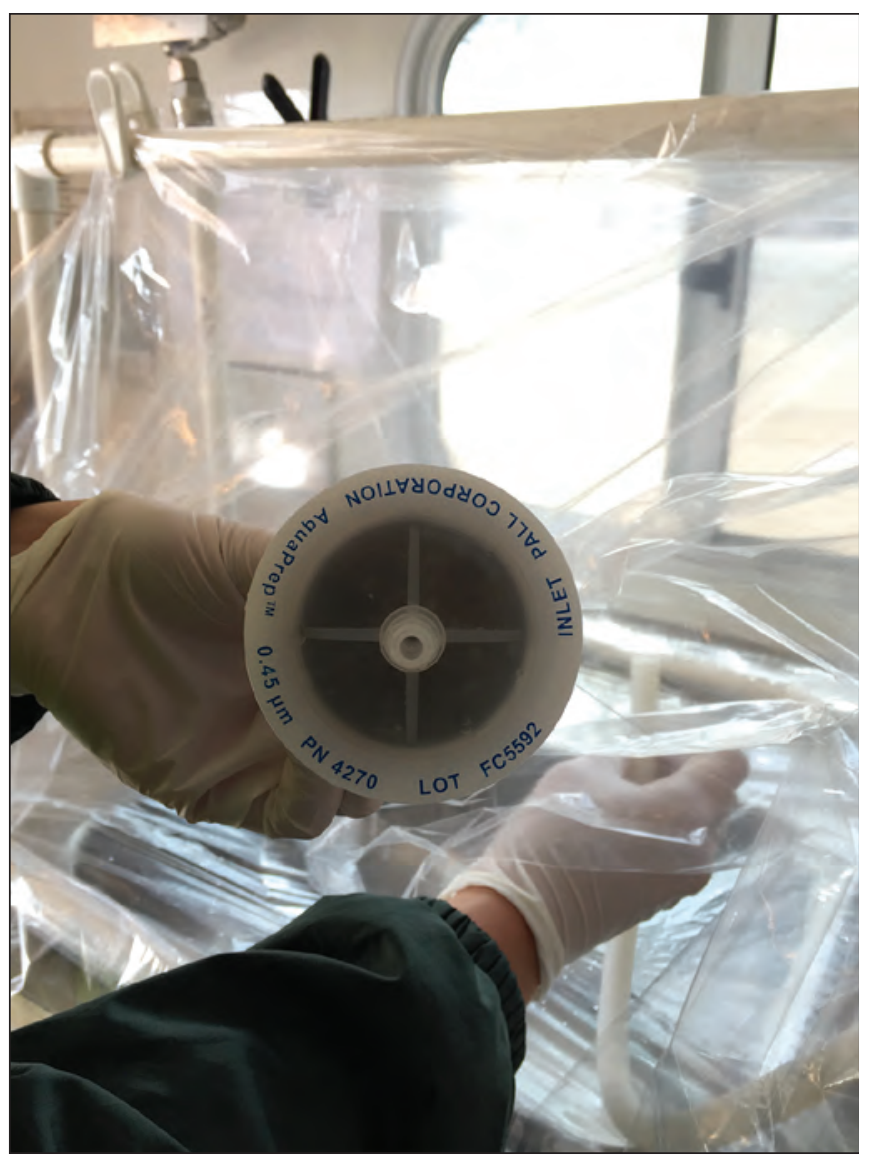

Figure 12. $A$, Samplers retrieved from VA-1A that have black precipitate on the outsides, and $B$, filter from VA-1A, where black precipitate formed in the processing filter. Photographs by Alanna Jornigan, U.S. Geological Survey. 


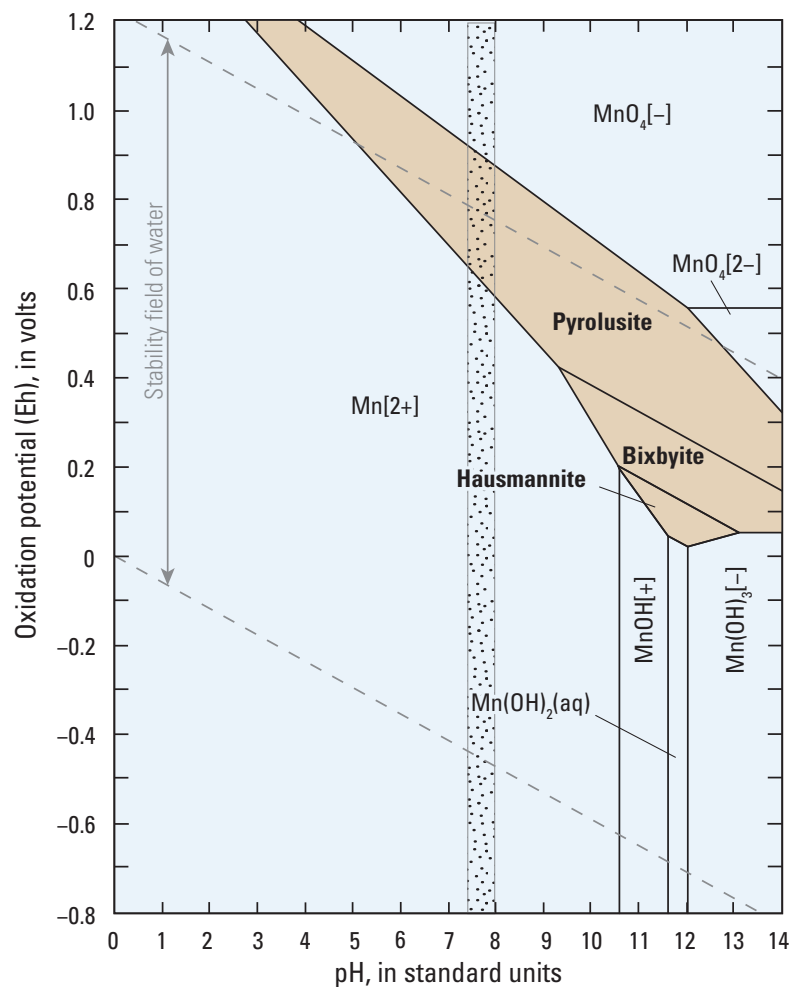

\section{EXPLANATION}

Aqueous phase

Solid phase

Range of $\mathrm{pH}$ values from the TR-1A and VA-1A passive and pumped samples (adapted from Takeno, 2005)

Figure 13. Eh-pH diagram of the system Manganese-0xygen-Hydrogen with $\mathrm{pH}$ values from the TR-1A and VA-1A passive and pumped samples (adapted from Takeno, 2005). 

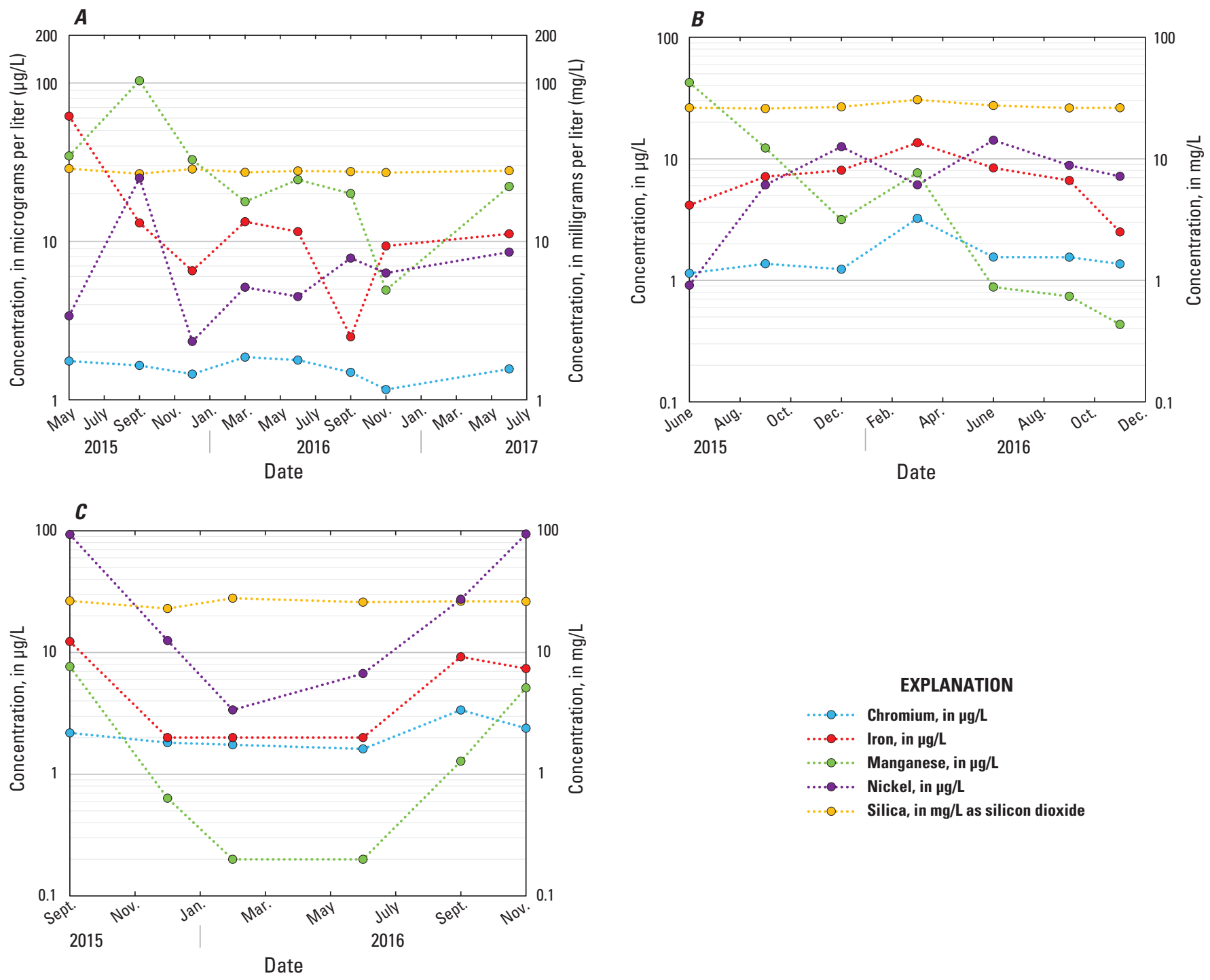

\section{EXPLANATION}

... . ... Chromium, in $\mu \mathrm{g} / \mathrm{L}$

........ Iron, in $\mu \mathrm{g} / \mathrm{L}$

........ Manganese, in $\mu \mathrm{g} / \mathrm{L}$

....... Nickel, in $\mu \mathrm{g} / \mathrm{L}$

. o... Silica, in $\mathrm{mg} / \mathrm{L}$ as silicon dioxide

Figure 14. Concentrations of selected trace elements from historical quarterly sampling using the pump method for $A$, TR-1A, $B$, CC-1A, and C, S0-1A, Kirtland Air Force Base, Albuquerque, New Mexico. 


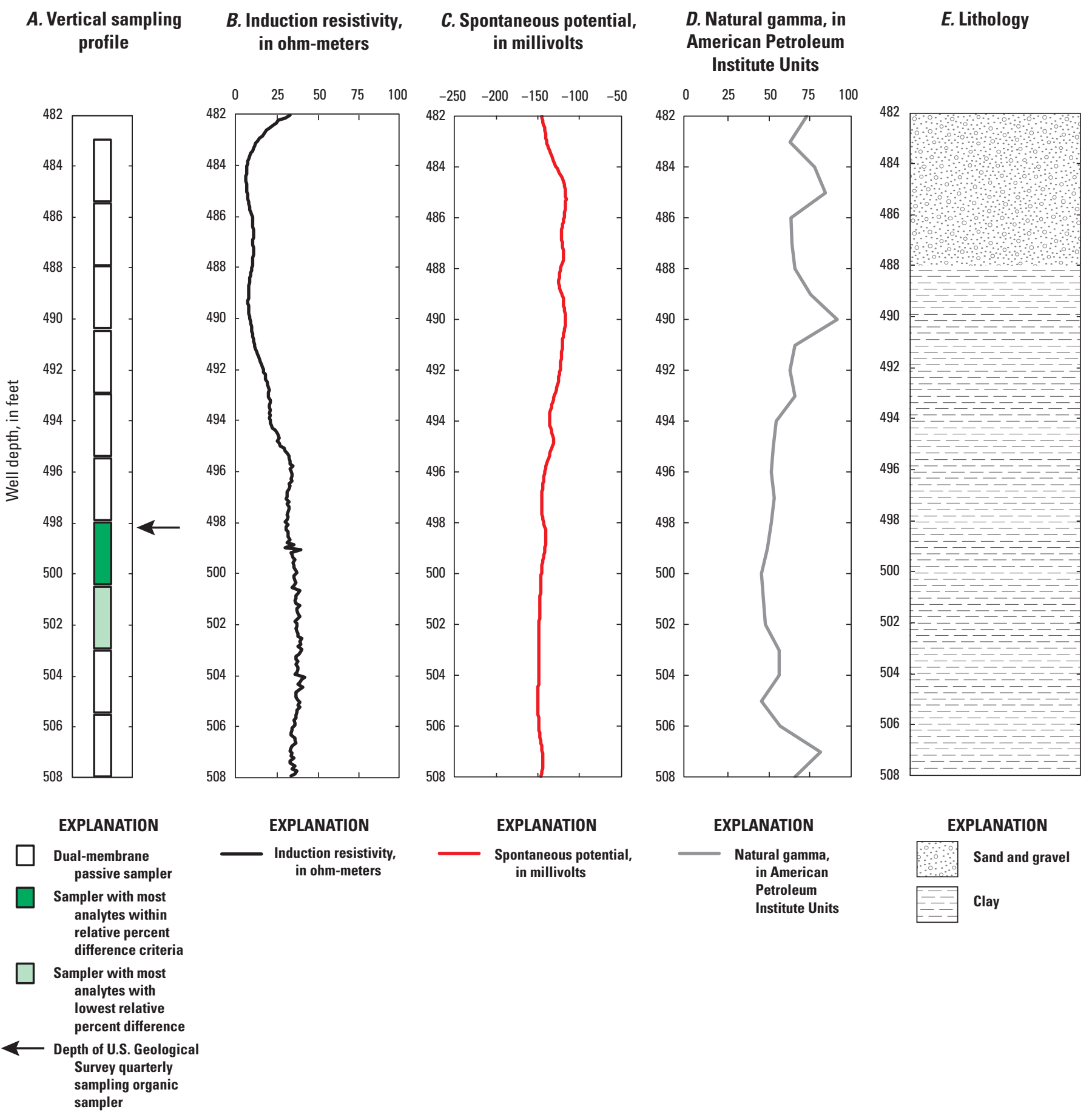

Figure 15. Vertical sampling profile at CC-1A showing $A$, the screened interval in which the passive samplers were placed and results of relative percent difference (RPD) analysis, $B, C$, and $D$, the results of geophysical logging (USGS, 2020), and $E$, the lithology (Bell and others, 2018), Kirtland Air Force Base, Albuquerque, New Mexico. 


\section{A. Vertical sampling profile}

B. Induction resistivity, in ohm-meters

\section{Spontaneous potential, in millivolts}

D. Natural gamma, in
American Petroleum Institute Units

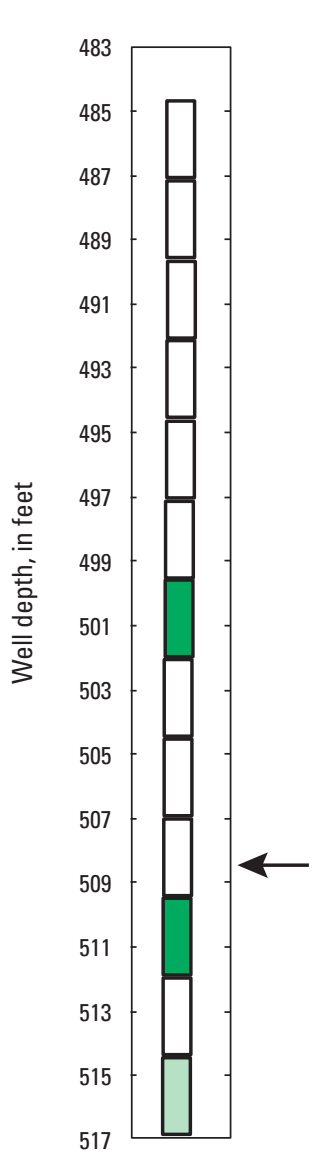

EXPLANATION

Dual-membrane passive sampler

Sampler with most analytes within relative percent difference criteria

Sampler with most analytes with lowest relative percent difference

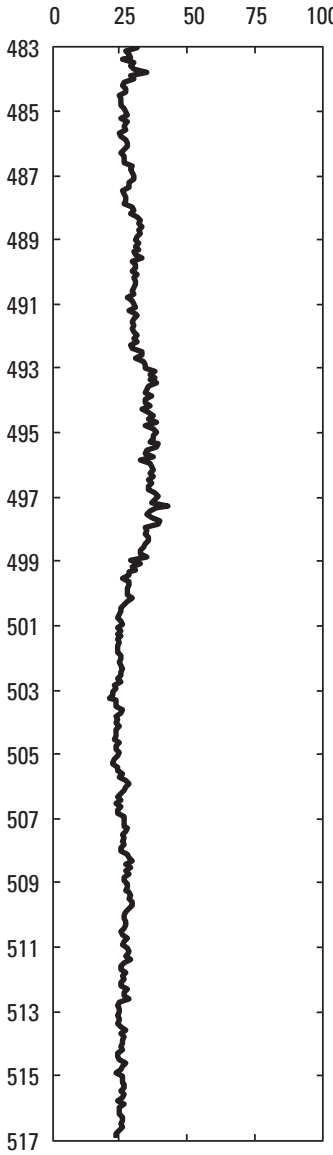

517

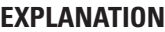

Induction resistivity in ohm-meters

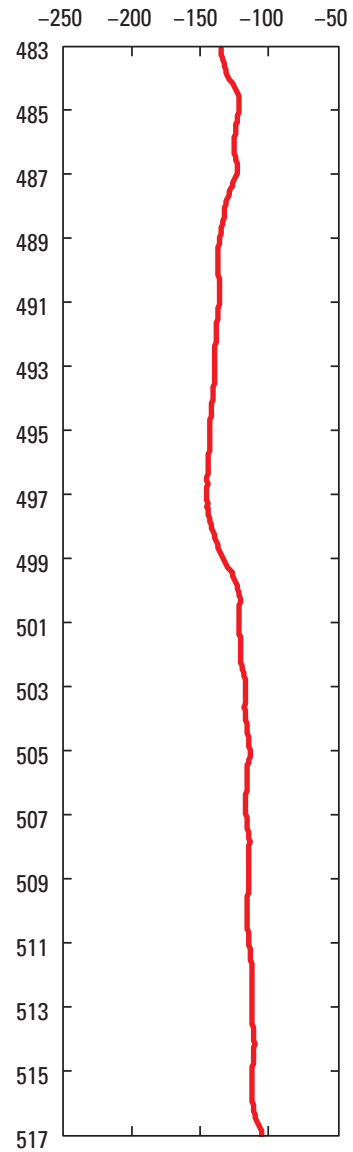

EXPLANATION

Spontaneous potential in millivolts

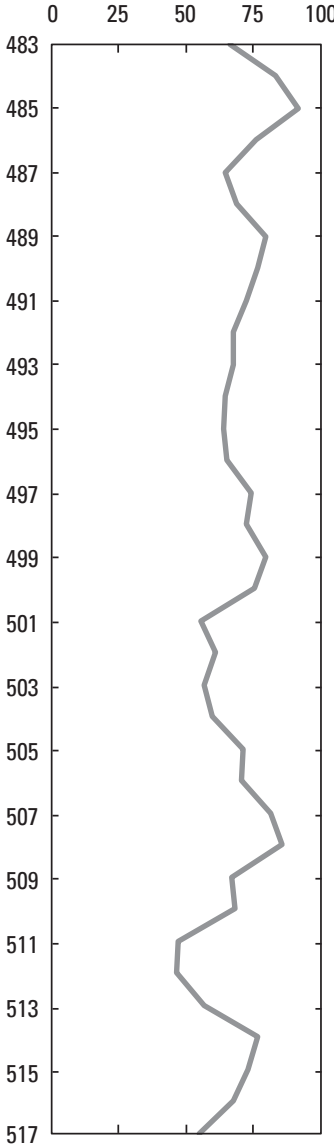

EXPLANATION

Natural gamma in American Petroleum Institute Units

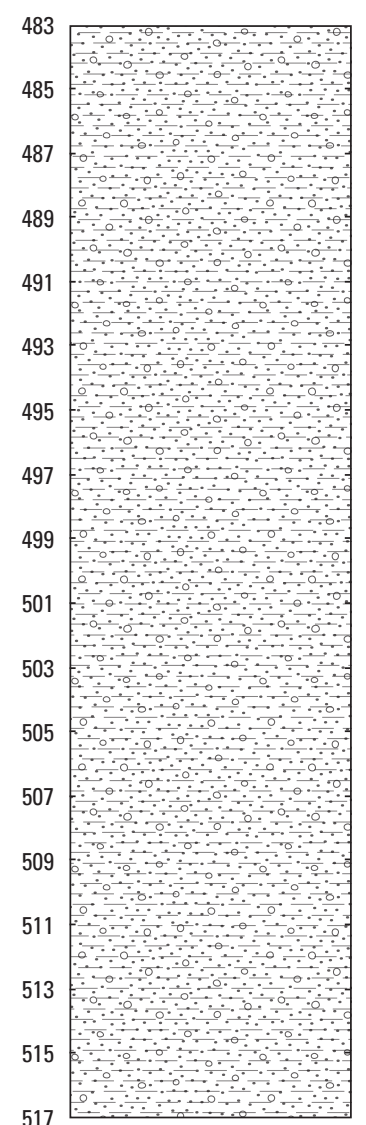

EXPLANATION

Sand and gravel with clay

\section{E. Lithology}

Depth of U.S. Geological

Survey quarterly

sampling organic

sampler

Figure 16. Vertical sampling profile at SO-1A showing $A$, the screened interval in which the passive samplers were placed and results of relative percent difference (RPD) analysis, $B, C$, and $D$, the results of geophysical logging (USGS, 2020), and $E$, the lithology (Bell and others, 2018), Kirtland Air Force Base, Albuquerque, New Mexico. 


\section{A. Vertical sampling profile}

B. Induction resistivity, in ohm-meters

\section{Spontaneous potential, in millivolts}
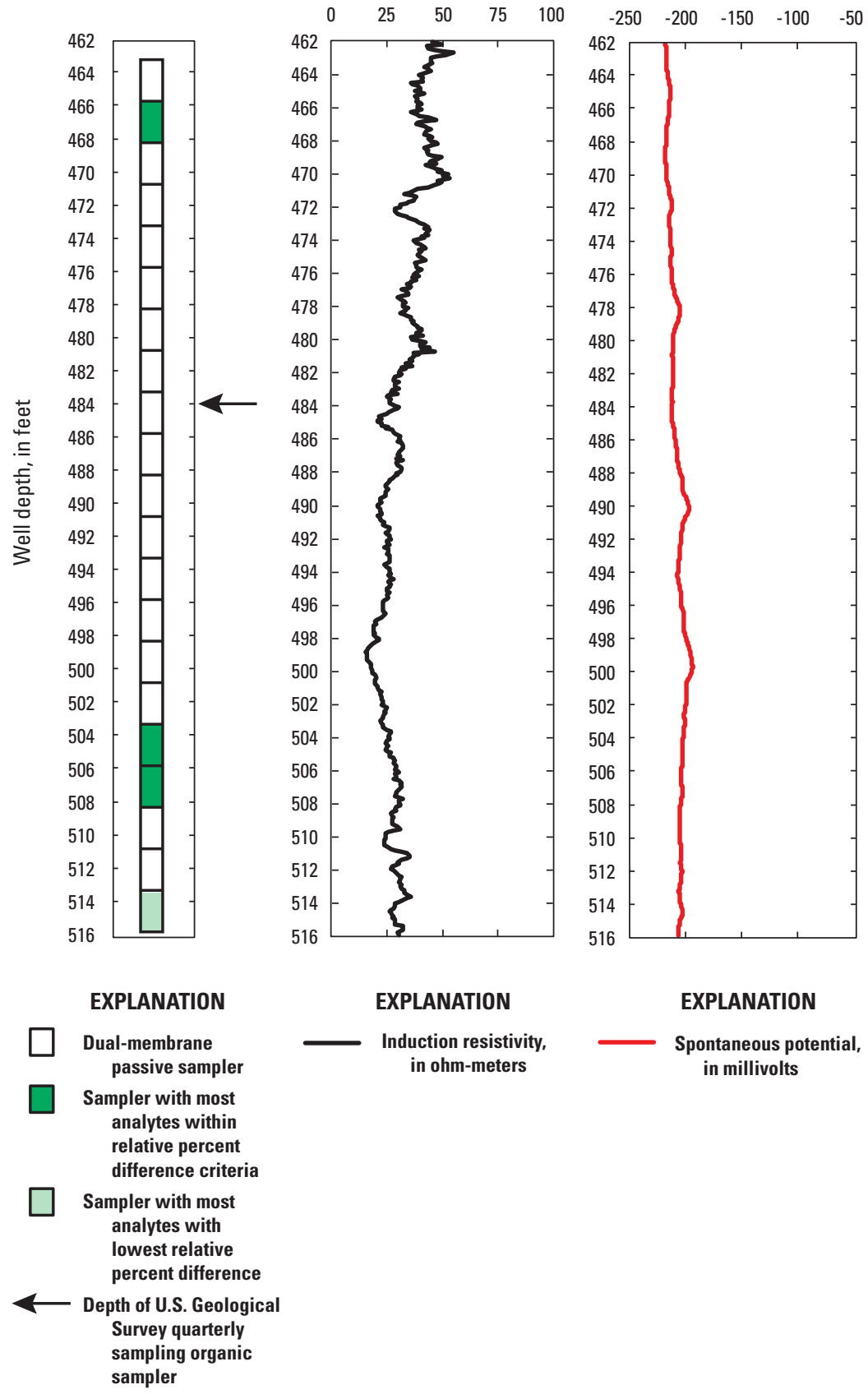

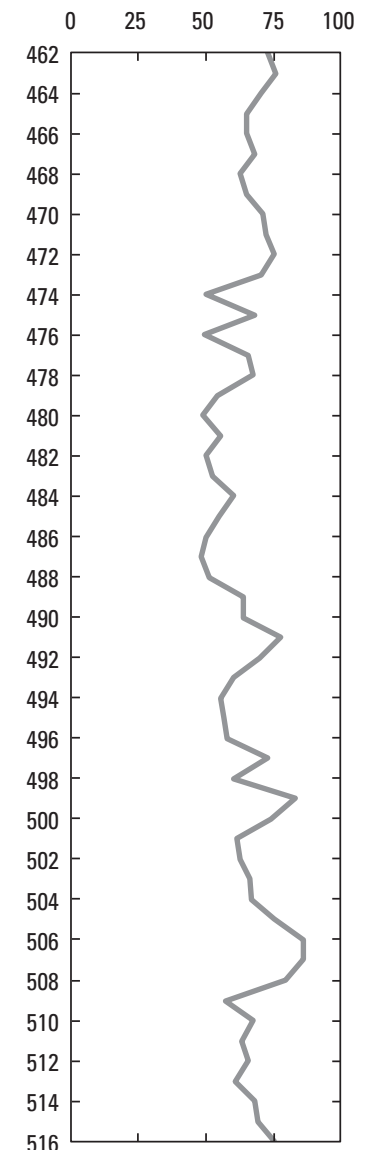

D. Natural gamma, in American Petroleum Institute Units

EXPLANATION

Natural gamma in American Petroleum Institute Units

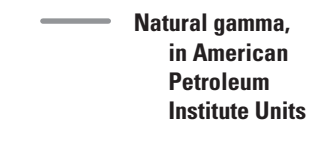

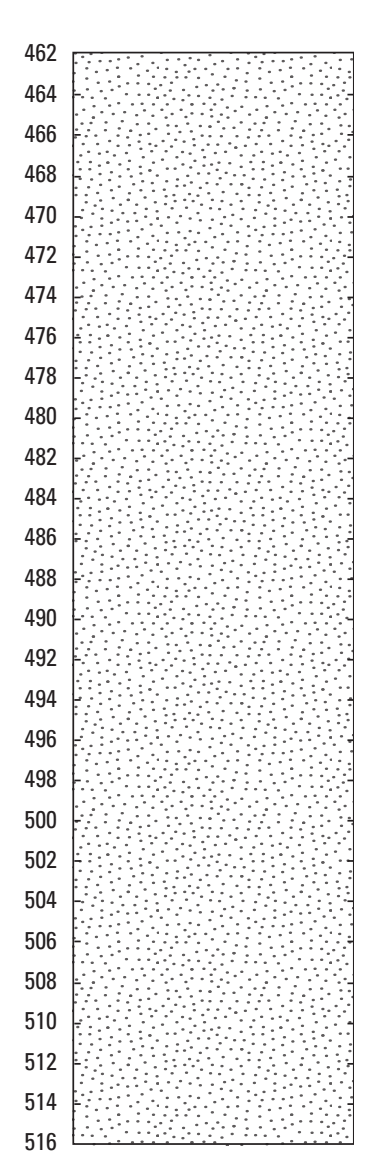

E. Lithology

EXPLANATION

Spontaneous potential, in millivolts

Figure 17. Vertical sampling profile at TR-1A showing $A$, the screened interval in which the passive samplers were placed and results of relative percent difference (RPD) analysis, $B, C$, and $D$, the results of geophysical logging (USGS, 2020), and $E$, the lithology (Bell and others, 2018), Kirtland Air Force Base, Albuquerque, New Mexico. 


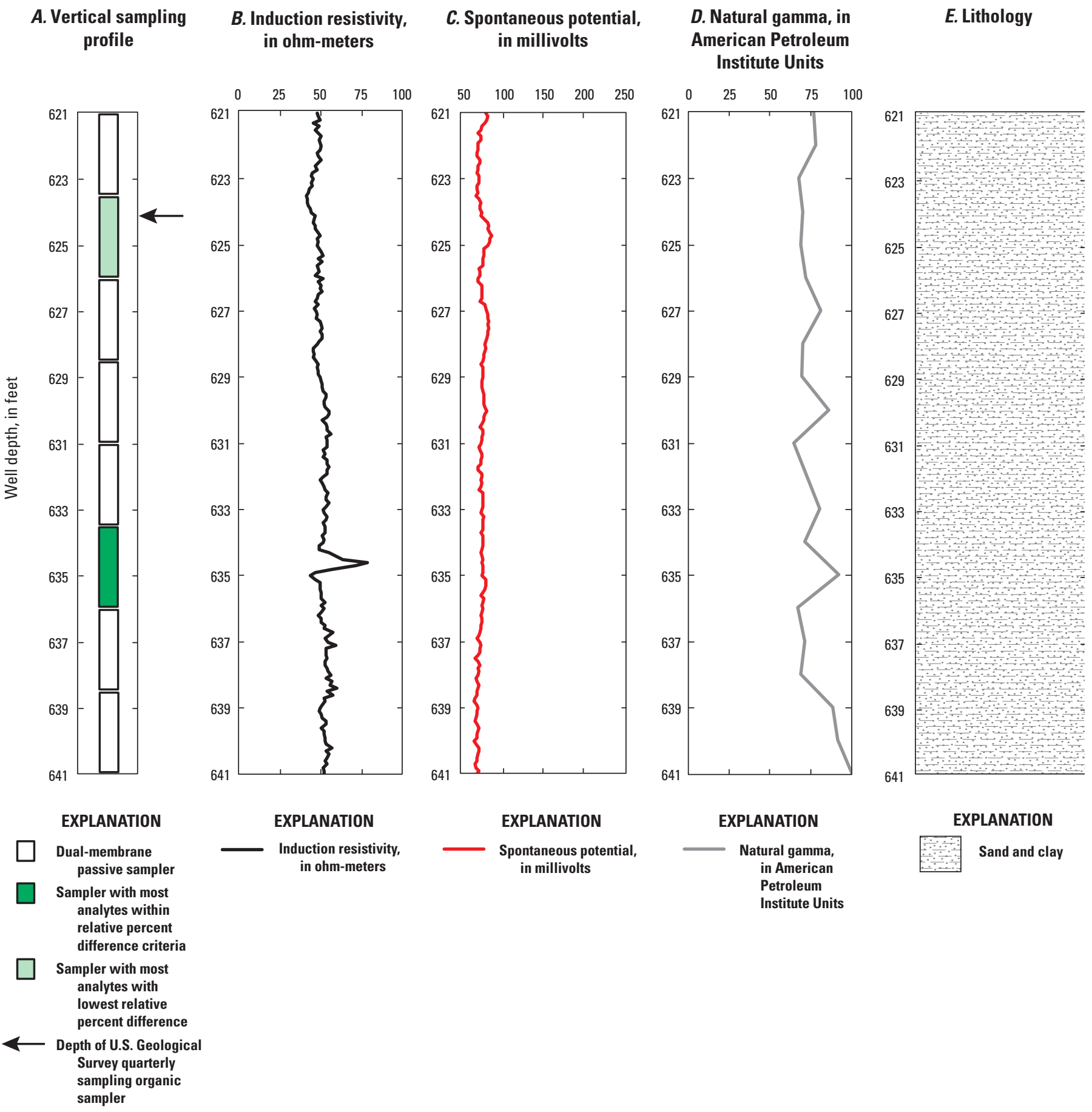

Figure 18. Vertical sampling profile at VA-1A showing $A$, the screened interval in which the passive samplers were placed and results of relative percent difference (RPD) analysis, $B, C$, and $D$, the results of geophysical logging (USGS, 2020), and $E$, the lithology (Bell and others, 2018), Kirtland Air Force Base, Albuquerque, New Mexico. 


\section{Summary}

An ethylene dibromide (EDB) plume extends northeast from the Bulk Fuels Facility area on Kirtland Air Force Base, New Mexico, and is upgradient from water-supply wells screened in an aquifer in the upper Santa Fe Group. In 2013, the U.S. Geological Survey (USGS) installed a nest of sentinel wells between the plume and water-supply wells because of concerns about possible contamination reaching the water supply. The four sentinel wells have been sampled by the USGS quarterly since 2015 and were sampled using a volumetric-purge pump sampling method until February 2017. In mid-2017, the USGS began using dual-membrane passive diffusion samplers. To ensure that these passive samplers are obtaining representative water chemistry samples, the USGS, in cooperation with the U.S. Air Force, initiated a study in 2019 to compare results from pump sampling and passive samplers and to determine the optimal depth for passive sampler placement in the screened interval to better inform long-term monitoring of the site.

A vertically profiled passive sampling study was conducted to help determine the depth at which the passive samplers would be best placed to produce representative water chemistry for the sentinel wells. The vertically profiled passive samplers, which were suspended throughout the submerged screened interval of the shallow sentinel wells, were compared to pump samples collected the day after the vertically profiled passive samplers were removed. Volatile organic compound results for this study were all below the raised reporting levels, which is a level five times the maximum concentration detected in a blank and determined by an in-depth quality assessment. Therefore, this study focused on an analysis of inorganic constituent results. The relative percent differences (RPDs) between the pump sampling and passive sampling results were evaluated. Additionally, the variability within each sampling method was analyzed.

The RPD analysis assessed whether the passive samplers under- or overreported concentrations based on the analysis of pump samples. Several analytes had an RPD value of plus or minus 50 percent. Most major differences between pump and passive samples seemed to be separated by well. In CC-1A and SO-1A, both wells had very high negative RPD values for manganese. TR-1A and VA-1 both had similarly high RPD values, with the passive samples having higher concentrations than the pump samples of manganese and lower concentrations of arsenic, nickel, selenium, sulfate, uranium, and vanadium. TR-1A also had very high passive sampling method concentrations for iron and molybdenum, which are likely caused by reduction/oxidation (redox) processes resulting from the oxic sampler water being introduced to an anoxic environment.
The estimated variability for each analyte was to be used as an analytical tool to determine if the differences between the results from both sampling methods were caused only by the sampling method variability. Most analytes, however, were not within the method variabilities. The estimated method variability for each analyte may still be useful to evaluate which analytes were not in agreement (that is, RPD criteria were not met or concentrations were not graphed near the 1-to-1 line) between the two sampling methods but were within the estimated variability for the sampling method.

Inherent differences in the two sampling methods could be the main causes for the differences in results. Passive samplers are representative of the last several days within a well but pumped samples are instantaneous samples from induced flow. Given the heterogeneity of the aquifer and the presence of interbedded muds, when the well is pumped, most of the water likely comes from the most conductive zones. In comparison, the passive samplers draw water locally that may not be from the most conductive portion of the aquifer. Redox processes within the wells could also be responsible for differences between trace element concentrations in passive samples and pump samples; the introduction of oxygen-rich blank water into anoxic environments appears to have affected the results at TR-1A and VA-1A.

After the evaluation of the RPD and the variability within the sampling methods, the deployment depths of the quarterly monitoring samplers were reviewed and evaluated to determine if the samplers are located in the most representative portion of the well. In CC-1A and SO-1A, the quarterly samplers could stay where they are currently located, since deployment in 2017, and likely collect a representative sample from the aquifer. Because of redox processes at TR-1A and VA-1A that likely interfere with analyte concentrations from the passive samplers, deoxygenated water is recommended for use at these wells. At TR-1A, the samplers could be placed at 504 feet below land surface, near samplers 17 and 18, which had the most agreement between the sample methods. At VA-1A, the sampler with the most analytes within the RPD criteria was near the interval where quarterly monitoring has been occurring, so the quarterly samplers could stay where they are in that well.

\section{Acknowledgments}

The authors would like to acknowledge the USGS hydrologic technicians who conducted the water-quality sampling and colleague reviewers, Phil Harte and Rebecca Frus, who provided constructive peer review. The authors would also like to acknowledge Kimberly Beisner, Johanna Blake, Nathan Myers, and Anne-Marie Matherne for their input in improving this report. 


\section{References Cited}

ASTM International, 2010, Standard practice for performing detection and quantitation estimation and data assessment utilizing DQCALC software, based on ASTM practices D6091 and D6512 of Committee D19 on Water: West Conshohocken, Penn., ASTM International, ASTM D7510-10, 2 p. [Also available at https://www.astm.org/ Standards/D7510.htm.]

ASTM International, 2018, Standard guide for purging methods for wells used for ground-water quality investigationsDesignation D6452: West Conshohocken, Penn., ASTM International, 6 p. [Also available at https://www.astm.org/ Standards/D6452.htm.]

Bartolino, J.R., and Cole, J.C., 2002, Ground-water resources of the Middle Rio Grande Basin, New Mexico: U.S. Geological Survey Circular 1222, 132 p. [Also available at https://doi.org/10.3133/cir1222.]

Bell, M.T., Ferguson, C., and Brown, J.E., 2018, Description of groundwater monitoring wells installed at and near Kirtland Air Force Base, Albuquerque, New Mexico, 2013-2016 (ver. 1.2, April 2019): U.S. Geological Survey data release, https://doi.org/10.5066/F7NV9HHG.

Bennett Sample Pumps, Inc., 2020, Bennett sample pumpsPump details: Amarillo, Tex., Bennett Sample Pumps, Inc., web page, accessed June 30, 2020, at http://www.be nnettsamplepump.com/Brochureemail.pdf.

Bexfield, L.M., and Anderholm, S.K., 2002, Spatial patterns and temporal variability in water quality from City of Albuquerque drinking-water supply wells and piezometer nests, with implications for the ground-water flow system: U.S. Geological Survey Water-Resources Investigations Report 2001-4244, 101 p. [Also available at https://doi.org/ 10.3133/wri014244.]

Borch, T., Kretzschmar, R., Kappler, A., Cappellen, P.V., Ginder-Vogel, M., Voegelin, A., and Campbell, K., 2010, Biogeochemical redox processes and their impact on contaminant dynamics: Environmental Science \& Technology, v. 44, no. 1, p. 15-23, accessed April 29, 2020, at https://doi.org/10.1021/es9026248.

Connell, S.D., 2006, Preliminary geologic map of the Albuquerque-Rio Rancho metropolitan area and vicinity, Bernalillo and Sandoval Counties, New Mexico: New Mexico Bureau of Geology and Mineral Resources OpenFile Report 496, 2 pls.

Connell, S.D., Allen, B.D., and Hawley, J.W., 1998, Subsurface stratigraphy of the Santa Fe Group from borehole geophysical logs, Albuquerque area, New Mexico: New Mexico Geology, v. 20, no. 1, p. 2-7.
Connor, B.F., Rose, D.L., Noriega, M.C., Murtaugh, L.K., and Abney, S.R., 1998, Methods of analysis by the U.S. Geological Survey National Water Quality LaboratoryDetermination of 86 volatile organic compounds in water by gas chromatography/mass spectrometry, including detections less than reporting limits: U.S. Geological Survey Open-File Report 97-829, 78 p. [Also available at https://doi.org/10.3133/ofr97829.]

Divine, C.E., Madsen, L.L., Andrews, S.D., and SantangeloDreiling, T., 2005, Passive diffusion ground water samplers at a site with heterogeneous hydrostratigraphy-Pilot study results: Ground Water Monitoring and Remediation, v. 25, no. 1, p. 90-99, accessed June 5, 2019, at https://doi.org/ 10.1111/j.1745-6592.2005.0004.x.

EON Products, Inc., 2021, Dual Membrane Passive Diffusion Sampler (DMPDB ${ }^{\mathrm{TM}}$ ) Information web page, accessed April 29, 2021, at https://www.eonpro.com/dual-membranepassive-diffusion-sampler-draft-link/.

Fishman, M.J., ed., 1993, Methods of analysis by the U.S. Geological Survey National Water Quality LaboratoryDetermination of inorganic and organic constituents in water and fluvial sediments: U.S. Geological Survey OpenFile Report 93-125, 217 p. [Also available at https://doi.org/ 10.3133/ofr93125.]

Fishman, M.J., and Friedman, L.C., 1989, Methods for determination of inorganic substances in water and fluvial sediments: U.S. Geological Survey Techniques of WaterResources Investigations, book 5, chap. A1, 545 p. [Also available at https://doi.org/10.3133/twri05A1.]

Galanter, A.E., and Curry, L.T.S., 2019, Estimated 2016 groundwater level and drawdown from predevelopment to 2016 in the Santa Fe Group aquifer system in the Albuquerque area, central New Mexico: U.S. Geological Survey Scientific Investigations Map 3433, 1 sheet, 13-p. pamphlet, accessed August 6, 2019, at https://doi.org/ $10.3133 / \operatorname{sim} 3433$.

Garbarino, J.R., 1999, Methods of analysis by the U.S. Geological Survey National Water Quality LaboratoryDetermination of dissolved arsenic, boron, lithium, selenium, strontium, thallium, and vanadium using inductively coupled plasma-mass spectrometry: U.S. Geological Survey Open-File Report 99-093, 31 p. [Also available at https://doi.org/10.3133/ofr9993.]

Garbarino, J.R., Kanagy, L.K., and Cree, M.E., 2005, Determination of elements in natural-water, biota, sediment and soil samples using collision/reaction cell inductively coupled plasma-mass spectrometry: U.S. Geological Survey Techniques and Methods, book 5, chap. B1, 88 p. 
Hawley, J.W., Haase, C.S., and Lozinsky, R.P., 1995, An underground view of the Albuquerque Basin, in OrtegaKlett, C.T., ed., The water future of Albuquerque and the Middle Rio Grande Basin-Proceedings of the 39th Annual New Mexico Water Conference, Albuquerque, N. Mex., November 3-4, 1994: New Mexico Water Resources Research Institute WRRI Report No. 290, p. 37-55.

Helsel, D.R., 2012, Statistics for censored environmental data using Minitab ${ }^{\circledR}$ and R (2d ed.): Hoboken, New Jersey, John Wiley \& Sons, Inc., 324 p.

Imbrigiotta, T.E., and Harte, P.T., 2020, Passive sampling of groundwater wells for determination of water chemistry: U.S. Geological Survey Techniques and Methods, book 1, chap. D8, 80 p., accessed May 6, 2020, at https://doi.org/ $10.3133 / \mathrm{tm} 1 \mathrm{~d} 8$.

Jurgens, B.C., McMahon, P.B., Chapelle, F.H., and Eberts, S.M., 2009, An Excel workbook for identifying redox processes in ground water: U.S. Geological Survey Open-File Report 2009-1004, 8 p. [Also available at https://doi.org/ 10.3133/ofr20091004.]

Keys, W.S., 1990, Borehole geophysics applied to groundwater investigations: U.S. Geological Survey Techniques of Water-Resources Investigations, book 2, chap. E2, $150 \mathrm{p}$. [Also available at https://doi.org/10.3133/twri02E2.]

Lapham, W.W., Wilde, F.D., and Koterba, M.T., 1995, Ground-water data-collection protocols and procedures for the National Water-Quality Assessment ProgramSelection, installation, and documentation of wells, and collection of related data: U.S. Geological Survey OpenFile Report 95-398, 79 p., accessed June 30, 2019, at https://doi.org/10.3133/ofr95398.

Lee, L., 2015, Package 'NADA'-Nondetects and data analysis for environmental data, version 1.5-6: The Comprehensive R Archive Network web page, accessed December 2016 at https://cran.r-project.org/web/packages/ NADA/NADA.pdf.

McMahon, P.B., and Chapelle, F.H., 2008, Redox processes and water quality of selected principal aquifer systems: Ground Water, v. 46, no. 2, p. 259-271.

Mueller, D.K., Schertz, T.L., Martin, J.D., and Sandstrom, M.W., 2015, Design, analysis, and interpretation of field quality-control data for water-sampling projects: U.S. Geological Survey Techniques and Methods, book 4, chap. C4, 54 p., accessed May 1, 2020, at https://doi.org/ $10.3133 / \mathrm{tm} 4 \mathrm{C} 4$.
Myers, N.C., and Friesz, P.J., 2019, Hydrogeologic framework and delineation of transient areas contributing recharge and zones of contribution to selected wells in the upper Santa Fe Group aquifer, southeastern Albuquerque, New Mexico, 1900-2050: U.S. Geological Survey Scientific Investigations Report 2019-5052, 73 p., accessed September 15, 2019, at https://doi.org/10.3133/sir20195052.

National Oceanic and Atmospheric Administration [NOAA], 2020, Climate data online: National Oceanic and Atmospheric Administration online database, accessed February 11, 2020, at https://www.ncdc.noaa.gov/cdo-web/ datasets/GHCND/stations/GHCND:USW00023050/detail.

New Mexico Environment Department, 2010, Hazardous waste treatment facility operating permit issued to U.S. Air Force for the Open Detonation Unit located at Kirtland Air Force Base, Bernalillo County, New Mexico: New Mexico Environment Department Hazardous Waste Bureau, EPA ID no. NM9570024423, accessed April 22, 2021, at https://hwbdocuments.env.nm.gov/Kirtland\%20AFB/ KAFB4654.pdf.

Nowell, L.H., Ludtke, A.S., Mueller, D.K., and Scott, J.C., 2013, Organic contaminants, trace and major elements, and nutrients in water and sediment sampled in response to the Deepwater Horizon oil spill: U.S. Geological Survey Scientific Investigations Report 2012-5228, 96 p., accessed May 1, 2020, at https://doi.org/10.3133/sir20125228.

Plummer, L.N., Bexfield, L.M., Anderholm, S.K., Sanford, W.E., and Busenberg, E., 2012, Geochemical characterization of ground-water flow in the Santa Fe Group aquifer system, Middle Rio Grande Basin, New Mexico (ver. 1.2, November 20, 2012): U.S. Geological Survey WaterResources Investigations Report 03-4131, 395 p., 1 CDROM in pocket. [Also available at https://doi.org/10.3133/ wri034131.]

Powell, R.I., and McKean, S.E., 2014, Estimated 2012 groundwater potentiometric surface and drawdown from predevelopment to 2012 in the Santa Fe Group aquifer system in the Albuquerque metropolitan area, central New Mexico: U.S. Geological Survey Scientific Investigations Map 3301, 1 sheet, accessed August 14, 2017, at https://doi.org/ 10.3133/sim 3301 .

R Core Team, 2015, R-A language and environment for statistical computing: Vienna, Austria, R Foundation for Statistical Computing, accessed December 2016 at https://www.R-project.org/.

Révész, K., and Coplen, T.B., eds., 2008a, Methods of the Reston Stable Isotope Laboratory-Determination of the $\delta\left({ }^{2} \mathrm{H} /{ }^{1} \mathrm{H}\right)$ of water-RSIL lab code 1574: U.S. Geological Survey Techniques and Methods, book 10, chap. C1, 27 p. [Also available at https://doi.org/10.3133/tm10C1.] 
Révész, K., and Coplen, T.B., eds., 2008b, Methods of the Reston Stable Isotope Laboratory-Determination of the $\delta\left({ }^{18} \mathrm{O} /{ }^{16} \mathrm{O}\right)$ of water-RSIL lab code 489: U.S. Geological Survey Techniques and Methods, book 10, chap. C2, 28 p. [Also available at https://doi.org/10.3133/tm10C2.]

Smith, K.S., 2007, Strategies to predict metal mobility in surficial mining environments, in DeGraff, J.V., ed., Understanding and responding to hazardous substances at mine sites in the western United States: Geological Society of America Reviews in Engineering Geology, v. 17, p. 25-45, accessed November 8, 2020, at https://doi.org/ 10.1130/2007.4017(03).

Takeno, N., 2005, Atlas of Eh-pH diagrams (Intercomparison of thermodynamic databases), Tsukuba, Ibaraki, Japan: National Institute of Advanced Industrial Science and Technology, Research Center for Deep Geological Environments, Geological Survey of Japan Open File Report No. 419, 287 p.

Thorn, C.R., McAda, D.P., and Kernodle, J.M., 1993, Geohydrologic framework and hydrologic conditions in the Albuquerque Basin, central New Mexico: U.S. Geological Survey Water-Resources Investigations Report 93-4149, 106 p. [Also available at https://doi.org/10.3133/ wri934149.]

Travis, R.E., and Myers, N.C., 2019, Hydraulic and waterquality indicators of aquifer zones contributing groundwater flow to wells in the Santa Fe Group aquifer system near southeast Albuquerque, New Mexico, 2013-16 (ver. 1.1, May 2019): U.S. Geological Survey Scientific Investigations Report 2018-5138, 21 p., accessed March 11, 2020, at https://doi.org/10.3133/sir20185138.

U.S. Air Force, 2011, Kirtland Air Force Base Bulk Fuel Facility spill assessment report- Report to Congressional committees, March 2011: U.S. Congress H.R. 111-201, $17 \mathrm{p}$.

U.S. Army Corps of Engineers [USACE], 2016, Kirtland Air Force Base quarterly monitoring report, JulySeptember 2016, Bulk Fuels Facility, Solid Waste Management Unit ST-106/SS-111: Albuquerque, New Mexico, PBC, prepared by EA Engineering Science and Technology, Inc., [variously paged].

U.S. Army Corps of Engineers [USACE], 2019, Kirtland Air Force Base quarterly monitoring report, April-June 2019, Bulk Fuels Facility, Solid Waste Management Unit ST-106/ SS-111: Albuquerque, New Mexico, PBC, prepared by EA Engineering Science and Technology, Inc., [variously paged].
U.S. Army Corps of Engineers [USACE], 2020, Kirtland Air Force Base quarterly monitoring report, April-June 2020, Bulk Fuels Facility, Solid Waste Management Unit ST-106/ SS-111: New Mexico Environment Department, prepared by EA Engineering Science and Technology, Inc.

U.S. Environmental Protection Agency [EPA], 1989, Data evaluation, chap. 5 in Risk assessment guidance for Superfund-Volume I, human health evaluation manual (part A): Washington, D.C., Office of Emergency and Remedial Response, U.S. Environmental Protection Agency Report EPA/540/1-89/002, 30 p., accessed September 23, 2011, at https://www.epa.gov/oswer/riskassessment/ragsa/ pdf/ch5.pdf.

U.S. Environmental Protection Agency [EPA], 2006, Method $8260 \mathrm{C}$ volatile organic compounds by gas chromatography/ mass spectrometry: U.S. Environmental Protection Agency, 92 p., accessed March 10, 2020, at https://www.epa.gov/ sites/production/files/2018-06/documents/method_8260c_ rev_3_8-1-2006.pdf.

U.S. Environmental Protection Agency [EPA], 2020, Drinking water contaminants: U.S. Environmental Protection Agency database, accessed June 29, 2020, at https://www.epa.gov/ ground-water-and-drinking-water/national-primarydrinking-water-regulations.

U.S. Geological Survey [USGS], 2015, Changes to National Water Quality Laboratory (NWQL) procedures used to establish and verify laboratory detection and reporting limits: U.S. Geological Survey National Water Quality Laboratory Technical Memorandum 2015.02, accessed March 10, 2020, at http://wwwnwql.cr.usgs.gov/tech memos/nwql.2015-02.pdf.

U.S. Geological Survey [USGS], 2019, USGS water data for the Nation: U.S. Geological Survey National Water Information System database, accessed October 24, 2019, at https://doi.org/10.5066/F7P55KJN.

U.S. Geological Survey [USGS], 2020, USGS GeoLog Locator: U.S. Geological Survey online database, accessed January 24, 2020, at https://webapps.usgs.gov/ GeoLogLocator.

U.S. Geological Survey [USGS], [variously dated], National field manual for the collection of water-quality data: U.S. Geological Survey Techniques of Water-Resources Investigations, book 9, chaps. A1-A10. [Also available at https://pubs.water.usgs.gov/twri9A.] 
For more information about this publication, contact

Director, New Mexico Water Science Center

U.S. Geological Survey

6700 Edith Blvd. NE

Albuquerque, NM 87113

For additional information visit

https://www.usgs.gov/centers/nm-water

Publishing support provided by

Lafayette Publishing Service Center 



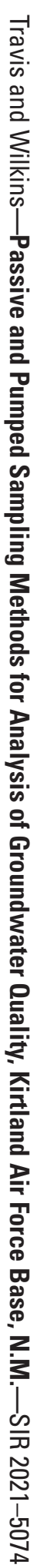

